UNIVERSIDADE DE SÃO PAULO

FACULDADE DE FILOSOFIA, LETRAS E CIÊNCIAS HUMANAS

DEPARTAMENTO DE LETRAS CLÁSSICAS E VERNÁCULAS

PROGRAMA DE PÓS-GRADUAÇÃO EM LETRAS CLÁSSICAS

\title{
Para além do limes: A Germania de Tácito em gênero e germano (Exemplar corrigido)
}

\author{
Henrique Verri Fiebig
}

Dissertação apresentada ao Programa de Pós-Graduação em Letras Clássicas do Departamento de Letras Clássicas e Vernáculas da Faculdade de Filosofia, Letras e Ciências Humanas da Universidade de São Paulo, para obtenção do título de mestre.

Orientador: Prof. Dr. Paulo Martins

São Paulo

2014 


\section{UNIVERSIDADE DE SÃO PAULO}

FACULDADE DE FILOSOFIA, LETRAS E CIÊNCIAS HUMANAS

DEPARTAMENTO DE LETRAS CLÁSSICAS E VERNÁCULAS

PROGRAMA DE PÓS-GRADUAÇÃO EM LETRAS CLÁSSICAS

\section{Para além do limes: A Germania de Tácito em gênero e germano}

\section{(Exemplar corrigido)}

Dissertação apresentada ao Programa de Pós-Graduação em Letras Clássicas do Departamento de Letras Clássicas e Vernáculas da Faculdade de Filosofia, Letras e Ciências Humanas da Universidade de São Paulo, para obtenção do título de mestre.

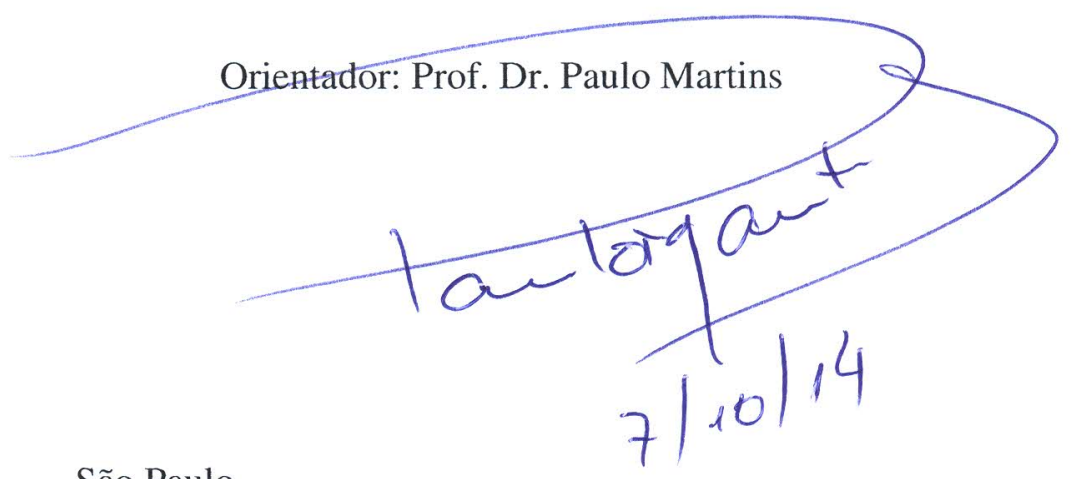

São Paulo

2014 
Nome: FIEBIG, Henrique Verri

Título: Para além do limes: a Germania de Tácito em gênero e germanos

Dissertação apresentada ao Programa de Pós-Graduação em Letras Clássicas do Departamento de Letras Clássicas e Vernáculas da Faculdade de Filosofia, Letras e Ciências Humanas da Universidade de São Paulo, para obtenção do título de mestre.

Aprovado em:

Banca Examinadora: 


\title{
Resumo
}

Nesta pesquisa, apresentamos uma nova tradução da Germania de Tácito para o português brasileiro, acompanhada de um estudo literário, no qual nos ocuparemos, primeiramente, do estabelecimento do gênero literário deste texto e dos problemas e dificuldades próprios deste e, depois, da construção do êthos da população germânica na obra, considerando preceitos do gênero epíditico da retórica e conceitos relativos à ekphrasis.

Palavras-chave: Etnografia antiga; Historiografia; Gênero epidítico; Ekphrasis.

\begin{abstract}
In this research, we present a new translation of Tacitus' Germania to Brazilian Portuguese. It is preceded by a literary study that firstly investigates the establishment of the literary genre of Tacitus' text and the problems that arise from it, and then, the construction of the êthos of the Germanic people in Tacitus' work, considering rhetorical precepts from the epideictic genre and concepts related to ekphrasis.
\end{abstract}

Keywords: Ancient ethnography; Historiography; Epideictic genre; Ekphrasis. 


\section{Agradecimentos}

Agradeço à Fundação de Amparo à Pesquisa do Estado de São Paulo, a FAPESP, pela concessão da bolsa de mestrado que permitiu a realização da pesquisa cujo resultado será neste texto apresentado.

À minha família: pater Fernando, mater Clarice e frater João Vitor, pelo mais variado apoio durante toda a minha vida acadêmica.

À Cristiani Vieira, pelo amor e carinho a mim dispensados durante quase dois anos.

Aos amigos: Alessandro Zaidem, Andrew Wellington, Bruno Hübscher, Bruno Messina Coimbra, Daniel Almeida, Gabriel Cremonine, Lucas Lima Furió, Luis Paulo Maziero, Michel Branco, Newton Schner Jr., Rafael Franco Rosa, Raffael Arini, Thiago Oliveira, Victor Estefano Mesquita e Wagner Chugaste, pelas boas conversas e agradáveis momentos durante os muitos anos de amizade.

Às amigas e colegas do grupo Imagens da Antiguidade Clássica - IAC: Cecília Gonçalves Lopes, Cynthia Helena Dibbern, Irene Cristina Boschiero, Lya Valéria Grizzo Serignoli e Melina Rodolpho, pelas aventuras de desventuras nas várias apresentações em congressos e viagens em que estivemos juntos.

Ao Prof. Dr. Andrew Feldherr, que me recebeceu, mui gentilmente, para um estágio de pesquisa blibiográfica na Firestone Library na Princeton University, EUA, em fevereiro de 2014.

A todos os professores com quem tive o prazer de aprender durante a minha vida acadêmica, em especial aos que acompanharam, de alguma forma, este meu trabalho durante a pós-graduação: Prof. Dr. Alexandre Pinheiro Hasegawa, Prof. Dr. Henrique Fortuna Cairus, Prof. Dr. Breno Battistin Sebastiani e Prof. Dr. Sidnei C. de Lima.

Ao Prof. Dr. João Adolfo Hansen e ao Prof. Dr. Fábio Faversani, pela honra de poder contar com seus fundamentais conselhos e apontamentos durante a banca de qualificação, em abril de 2013, os quais muito contribuíram para a realização desta dissertação. 
Por fim, ao mais querido magister, Prof. Dr. Paulo Martins, pela oportunidade de poder trabalhar junto dele durante os últimos anos, pelas muitas portas que me abriu e pela paciência com este orientando nem sempre o mais organizado e disciplinado. 


\section{Sumário}

Resumo / Abstract 3

$\begin{array}{lr}\text { Agradecimentos } & 4\end{array}$

$\begin{array}{ll}\text { 1. Introdução } & 7\end{array}$

2. Sobre o gênero literário da Germania de Tácito 9

2.1. O estabelecimento do gênero literário da Germania pela crítica 9 moderna

2.2. O Gênero Etnográfico Antigo 12

2.3. A Germania como monografia etnográfica 20

2.4. Problemas do estabelecimento do gênero etnográfico antigo e a 28 Germania como monografia histórica

2.5. Monografia, história e o gênero demonstrativo da retórica 31

2.6. Conclusão 33

3. A construção do êthos dos germanos 35

3.1. A Germania como um retrato epidítico 35

3.2. A Germania como ekphraseis $\quad 50$

3.2.1. A Germania como topografia 52

3.2.2. A Germania como etopeia 55

3.3. Conclusão

4. Tradução da Germania de Tácito 58

5. Bibliografia 114 


\section{Introdução}

De Origine et situ Germanorum, mais conhecida como Germania, é uma das chamadas obras menores (opera minora) do historiador latino Públio Cornélio Tácito (56 - 117 d.C.), ao lado de De vita et moribus Iulii Agricolae e Dialogus de oratoribus, as quais constituem o corpus taciteano, em conjunto com os trabalhos de maior envergadura, Historiae e Annales.

Publicada, possivelmente, em 98 d.C. - portanto, após o Agricola e antes do Dialogus -, a Germania é tratada pelos estudiosos modernos como uma antiga monografia etnográfica, cuja matéria consiste, de modo geral, dos costumes e disposição geográfica das tribos da gente que os romanos identificavam como germani.

A obra é costumeiramente dividida em duas partes: do capítulo I ao XXVII, ela desenvolve os tópicos usuais do gênero etnográfico, enquanto que do capitulo XXVIII ao XLVI ela segue as convenções próprias ao gênero periegético, guiando o leitor através das regiões da Germânia e da localização de suas tribos.

Nesta nossa dissertação, apresentaremos uma tradução anotada da Germania para o português, acompanhada de estudo literário, que se focou em dois elementos em especial para reflexão sobre o texto: seu gênero literário e sua matéria, isto é, seus bárbaros. Evidentemente, tanto as características de gênero da obra quanto as particularidades de seus bárbaros germânicos já foram amplamente estudadas; todavia, acreditamos que podemos acrescentar um ou outro elemento novo à discussão.

Sabemos que há pelo menos um século a Germania tem sido considerada, quanto ao seu gênero literário, uma monografia etnográfica. Por isso, no primeiro capítulo, apresentaremos uma breve história da classificação da Germania como monografia etnográfica e do estabelecimento da etnografia como gênero; mas não só: a partir dos estudos sobre gênero literário que apareceram a partir da década de 1970, tentaremos uma interpretação um pouco diferente quanto ao gênero desta obra, ao entende-la como uma monografia historiográfica e ao aproximá-la ao gênero demonstrativo da retórica.

No segundo capítulo, estudaremos o êthos germânico também de uma forma um pouco distinta. Se até o momento entende-se que ele tenha se formado a partir de topoi e estereótipos próprios do gênero etnográfico, acrescentaremos que ele pode ter sido construído por Tácito a partir dos lugares-comuns próprios ao gênero demonstrativo ou epidíco da retórica, considerando as conclusões acerca do gênero da obra no capítulo 
anterior; deste modo, apresentaremos os germanos como uma espécie de retrato epidítico. Complementarmente, analisaremos este êthos também nos utilizando de teorias ecfrásticas.

Por fim, no terceiro e último capítulo, o leitor encontrará o texto latino da Germania de Tácito, acompanhado de seu respectiva tradução portuguesa anotada. 


\section{Sobre o gênero literário da Germania de Tácito}

Desde o primeiro momento em que a possibilidade de estudarmos a Germania de Tácito nos foi sugerida, a necessidade de uma reflexão acerca das características de gênero da obra se impôs. Tal imposição nasce tanto da particularidade do texto taciteano no âmbito das Letras Clássicas quanto dos apontamentos e conclusões expostos por estudiosos em mais de um século de estudos acadêmicos acerca deste; nasce, também, da urgência em estudá-lo tendo em mãos o aparato crítico que nos tem feito repensar o funcionamento do gênero e suas categorias nas últimas quatro décadas.

Levando isto em consideração, podemos traçar o plano do nosso estudo acerca do gênero literário da Germania de Tácito da seguinte forma: primeiramente, observaremos como os críticos que se ocuparam dela entendem suas especificidades e seu gênero; então, delinearemos as características do gênero ao qual ela pertence, segundo os críticos, tais como foram apresentadas pelos pesquisadores modernos que com ele se ocuparam; depois, reexaminaremos este gênero e seus traços principais sob a luz das mais recentes produções que tratam da natureza geral do gênero literário, de modo a procurar, por fim, novas possibilidades de interpretação para o texto do historiador latino.

\subsection{O estabelecimento do gênero literário da Germania pela crítica moderna}

É possível definir, como o início da discussão do gênero literário da Germania, o artigo publicado por Theodor Mommsen em 1886, Rede zur Feier des Geburtstages Friedrichs des Groszen ${ }^{1}$. Ao pensar a orientação literária do texto de Tácito, o estudioso alemão reconhece a relação entre o escrever da história e a geografia entre os antigos, apontando que frequentemente encontramos inseridos, nos trabalhos historiográficos gregos e romanos, extensas passagens que lidam com geografia, os quais funcionariam como digressões ou excursos e que teriam tênue ou nenhuma ligação com a narrativa principal$^{2}$. A Germania teria sido pensada, pois, como uma corografia [Chorographie], uma descrição geográfica a ser inserida por Tácito em suas Historiae. Mommsen apoia sua argumentação no fato de interessar às corografias os locais nos quais os mais recentes

\footnotetext{
${ }^{1}$ T. Mommsen (1909, pp. 144-53).

${ }^{2}$ Idem (pp. 151-2).
} 
conflitos se desenvolvem (sabemos que a Germânia era um destes locais). Segundo ele, a digressão teria acabado por ser publicada separadamente, transformando-se na Germania, por conta da envergadura e profundidade da descrição, o que prejudicaria, do ponto de vista da composição, a fluidez da narrativa ${ }^{3}$, ao contrário, por exemplo, da corografia da Palestina, breve o suficiente para ser mantida nas mesmas Historiae . $^{4}$

Nas duas primeiras décadas dos anos 1900, aparecem os estudos que começam a estabelecer o gênero literário da Germania mais decisivamente. Em 1900, Alfred Gudeman a denomina, na introdução ${ }^{5}$ à sua edição do texto, um tratado geográficoetnográfico [geographical-ethnographical treatise], ou ainda uma monografia geográfica-etnográfica [geographical-ethnographical monograph], designada para publicação independente. É, ao que parece, a primeira referência à Germania como uma monografia etnográfica feita por um comentador. Ademais, Gudeman indica, que o texto era ainda comumente visto como um tratado ético-político, o que ele refuta dizendo que Tácito não era nem retor filosófico nem teórico político ${ }^{6}$.

Em 1909 e 1918, surgem os dois estudos que serviram de base para a interpretação do gênero literário da Germania durante o século 20: Über die Entwicklung der griechischen Historiographie und den Plan einer neuen Sammlung der griechischen Historikerfragmente [Do desenvolvimento da historiografia grega e do plano para uma nova coletânea dos fragmentos dos historiadores gregos], de Felix Jacoby, e Studien zur Geschichte der grieschisch-römischen Ethlographie [Estudos sobre a história da etnografia greco-romana], de Karl Trüdinger. Observaremos ambos os trabalhos mais detalhadamente na próxima sessão, mas algumas palavras se fazem necessárias já agora.

Jacoby $^{7}$ coloca a etnografia [Ethnographie] como um segundo momento na linha de desenvolvimento da antiga historiografia grega e identifica algumas características gerais que lhe seriam atribuíveis: a descrição de regiões, de povos e de seus costumes. Trata, porém, do gênero etnográfico apenas nesse contexto, isto é, dentro do desenvolvimento da historiografia grega, e não apresenta um estudo de trabalhos etnográficos específicos, nem adentra o terreno das letras latinas.

\footnotetext{
${ }^{3} \operatorname{Idem}($ p. 152).

${ }^{4}$ Ver Tac., Hist., 5.1-13.

${ }^{5}$ A. Gudeman (1900, pp. xxix-lxxi).

${ }^{6} \operatorname{Idem}(\mathrm{p} . \mathrm{xlv}$, nota 1$)$.

${ }^{7}$ F. Jacoby (1956, pp. 16-64).
} 
Ora, a partir do plano traçado por Jacoby, Karl Trüdinger ${ }^{8}$ segue os rastros de uma possível tradição etnográfica antiga, greco-latina, e elenca uma série de topoi que seriam próprios do gênero etnográfico ${ }^{9}$. Trüdinger reconhece a particularidade do texto taciteano e a dificuldade que existe para definir sua forma literária, mas o identifica como um trabalho etnográfico autônomo [ein selbständiges ethnographisches Werk], semelhante às descrições de povos que aparecem, via de regra, como excursos em trabalhos maiores,

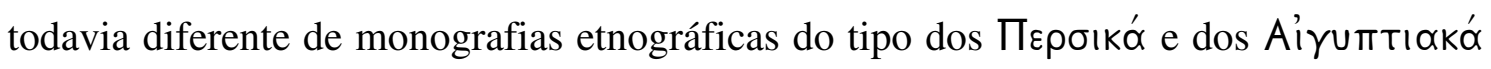
de Helânico de Lesbos ${ }^{10}$.

Após o trabalho de Trüdinger, há praticamente um consenso sobre a natureza do gênero literário do texto de Tácito entre os comentadores modernos.

Em 1923, no extenso tomo em que se ocupa com uma profunda análise da Germania, Norden aceita a noção de que ela está filiada à literatura etnográfica [ethnographische Literatur] ${ }^{11}$; Anderson diz que não há dúvidas sobre a qual gênero pertence: trata-se de uma ethnography ${ }^{12}$; Perret a situa também no contexto de uma littérature ethnographique ${ }^{13}$. Assim o fazem também comentadores mais recentes do texto, como Lund, que a vê como uma monografia etnográfica [ethnographische Einzelschrift ${ }^{14}$, e Rives, que a pensa como uma ethnographic monography que pertence a uma ethographic tradition ${ }^{15}$. Todavia, este último nota que a segunda metade do texto taciteano remonta mais propriamente à tradição periegética ${ }^{16}$.

Assim, temos que a Germania de Tácito é considerada uma monografia etnográfica pelos estudiosos modernos, portanto pertencente ao gênero etnográfico. Isto posto, podemos passar ao estudo pormenorizado desta tradição etnográfica, observando suas características de gênero, apontando também seus principais expoentes, até Tácito.

\footnotetext{
${ }^{8} \mathrm{~K}$. Tründiger (1918).

${ }^{9}$ Estudaremos estes topoi na sessão a seguir.

${ }^{10} \mathrm{~K}$. Trüdinger (1918, pp. 146-8).

${ }^{11}$ E. Norden (1998, p. 41).

12 J. G. C. Anderson (1997, pp. xiii-xvi). Originalmente publicado em 1938.

13 J. Perret (1949, p. 16).

${ }^{14}$ A. A. Lund (1988, pp. 17-19).

15 J. B. Rives (1999, pp. 11-21).

${ }^{16}$ Idem (p. 13).
} 


\subsection{O Gênero Etnográfico Antigo}

O primeiro estudioso a propor, decisivamente, a existência de um gênero etnográfico antigo e a delimitar suas características fundamentais foi o classicista e filólogo alemão Felix Jacoby (1876 - 1959), em seu artigo Über die Entwicklung der griechischen Historiographie und den Plan einer neuen Sammlung der griechischen Historikerfragmente publicado em $1909^{17}$ e já mencionado. Nele, Jacoby traça o desenvolvimento da historiografia tendo como ponto de partida dois trabalhos do grego Hecateu de Mileto e, a partir disso, delineia o plano para a organização da sua futura recolha dos fragmentos dos historiadores gregos, que veio a dar origem à sua monumental obra, Die Fragmente der griechischen Historiker.

Jacoby propõe que a organização dos fragmentos obedeça ao princípio do desenvolvimento histórico, já que este é, a seu ver, o único a oferecer base científica para tal tarefa; ademais, ele oferece a chance de ordenar os trabalhos historiográficos a partir dos gêneros literários, do tipo e formação de cada $\gamma \eta \dot{v} v \eta^{18}$, de suas características e idiossincrasias e também dos fios que os ligam uns aos outros $\left(1956\right.$, p. 19) ${ }^{19}$.

A historiografia grega teria tido seu início no século V a. C. com Hecateu de

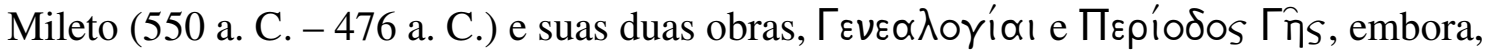
segundo o estudioso, Hecateu não possa ser chamado de historiador no sentido moderno da palavra (p. 20), acrescentando que o próprio termo historiografia [Historiographie] tem de ser tratado com cuidado e considerado em seu sentido antigo mais amplo, que não corresponde ao termo história [Geschichte] usado modernamente, pois a historiografia não se apresentava como uma ciência independente na Antiguidade, determinada a partir da pesquisa e narração de acontecimentos do passado próximo ou distante (p. 20).

Ora, segundo Jacoby, na obra de Hecateu jazem as sementes de três dos quatro principais gêneros da literatura historiográfica do séc. V: a genealogia [Genealogie], a etnografia [Ethnographie] e a história contemporânea [Zeitgeschichte] dos povos gregos; apenas a horografia [Horographie] não teria relação direta com o milésio (p. 22).

O Пвpíodos $\Gamma \hat{\eta} s$ rendeu dupla descendência literária: de um lado, a descrição etno-geográfica de cada nação bárbara, a etnografia; de outro, a periegese (p. 21).

\footnotetext{
${ }^{17}$ Primeiramente, na revista Klio, 9, e, posteriormente, em F. Jacoby (1956).

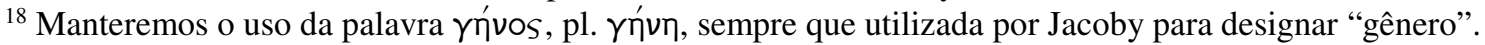

${ }^{19}$ Durante a exposição da reflexão de Jacoby, nos parágrafos seguintes, faremos a indicação da página no próprio corpo do texto, evitando assim o uso exagerado das notas de rodapé.
} 
Possivelmente, já havia relações geográficas-etnográficas sendo levadas a cabo antes de Hecateu, mas não se sabe ao certo se elas tomaram um sentido literário; e se tomaram, sua natureza literária teria sido diferente daquela da obra de Hecateu (p. 20).

Esta especificidade de seu texto impede tanto catalogá-lo como pertencente à literatura periegética - a qual se estabelece, já no século V a. C., como gênero literário próprio, seguindo um caminho particular, apesar da relação com a etnografia -, quanto demanda separá-lo, como historiador, dos geógrafos - embora a relação entre um e outro permaneça constante (pp. 20-1).

No decorrer do seu desenvolvimento literário, tanto a descrição etno-geográfica quanto a periegese enfatizam mais e mais o elemento histórico, sem perder, todavia, o caráter descritivo comum à toda literatura geográfica; a primeira incorpora cada vez mais elementos das $\Gamma \varepsilon v \varepsilon \alpha \lambda o \gamma i ́ \alpha ı$ e é continuamente influenciada de modo intensivo pela literatura histórica, pela história contemporânea ou Zeitgeschichte, enquanto que a

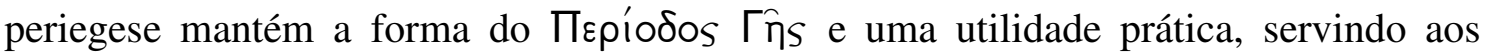
marinheiros (pp. 21-2).

Embora reconheça que o termo etnografia não seja utilizado na Antiguidade, Jacoby chama assim os trabalhos que descrevem não mais o mundo conhecido como um todo, mas uma única região, lançando mão de dados etnográficos e geográficos, e que são

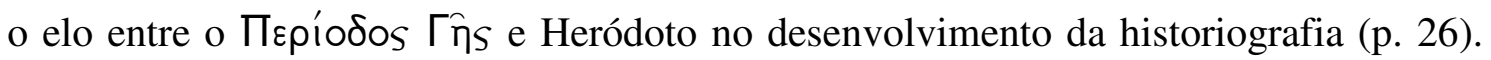
Acrescenta que, como a terminologia que denomina cada área de estudo historiográfico não havia sido suficientemente formada, não se diferenciavam muito horografia e etnografia, ou seja, a história analítica de cidades gregas e descrições geográficas e etnográficas de uma região e um povo bárbaro em particular, assim como, por vezes, de povos e tribos helênicas (p. 26).

Esses trabalhos etnográficos teriam surgido do desmembramento do Пвpíodos

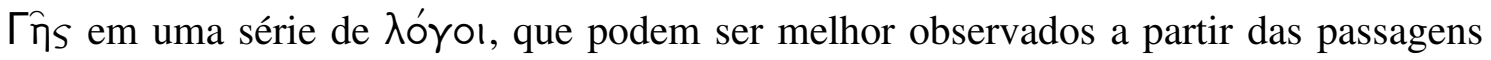
etnográficas em Heródoto, as quais mostram um esquema para a descrições de povos bárbaros que pode ser assim divido: 1) descrição da região ou nação; 2) de sua história

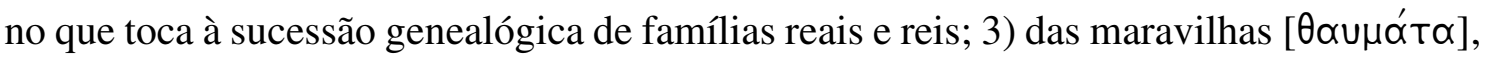
que constitui a estrutura principal da descrição; e 4) dos costumes [vómoı! dos habitantes (pp. 26-7).

A autonomia de uso destes $\lambda o ́ \gamma o$ e a natureza da matéria, tal como aparecem em Heródoto, dá forma ao novo $\gamma^{\varepsilon}$ voos da etnografia, cuja essência consiste, justamente, na 


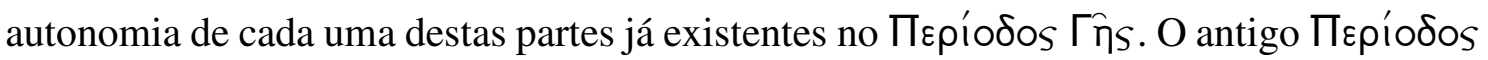
continha não somente descrições geográficas e etnográficas de regiões e povos, mas também tradições históricas, particularmente quando elas se ligassem aos monumentos naturais e artísticos de cada região; estes eram, todavia, ingredientes ocasionais, que não eram abundantes pela pequena extensão das obras. Daqui começa o desenvolvimento posterior, que se deu gradualmente e consistia na incorporação cada vez maior de elementos do mito e da história, sem que o elemento descritivo fundado na descrição topográfica e etnográfica tenha deixado de existir (p. 27).

Jacoby faz algumas observações importantes sobre a natureza do gênero etnográfico. Ele argumenta que uma verdadeira etnografia cobre sempre tudo o que há para se dizer acerca de uma região; que quando há várias etnografias acerca de um povo, as posteriores são revisões estendidas das anteriores; que este gênero possui diferenças significantes em relação às futuras 'E $\lambda \lambda \eta \eta$ ı $\alpha$, pois a etnografia é descritiva em sua origem, e não narrativa, como a Zeitgeschichte ${ }^{20}$ grega; e que as descrições de regiões e costumes de seus habitantes é sempre a base e ponto de partida dos etnógrafos, e que por isso permanece o caráter do gênero, mesmo quando o elemento narrativo, isto é, o elemento histórico, ganhou mais terreno em certas etnografias (p. 30).

Ademais, aponta que, no geral, há etnografias reais apenas sobre regiões politicamente independentes; que há a necessidade de se adaptar estilisticamente, por parte dos autores, o material mais antigo de modo a agradar ao gosto dos leitores de sua época, tal como se fazia no período helenístico; e que, posteriormente, surgiram obras que são coletâneas de etnografias anteriores, as quais são consideradas etnografias de fato, apesar do caráter distinto em relação àquelas produzidas pelo íotopín jônico (pp. 30-4).

Outros insights importantes acerca da natureza do gênero etnográfico nos são fornecidos durante sua reflexão sobre a obra de Heródoto e a Zeitgeschichte.

Jacoby considera Heródoto o primeiro representante do gênero que denomina Zeitgeschichte. Este gênero teria sido percebido como uma contrapartida às etnografias, no qual o pensamento histórico se impõe ao elemento descritivo, sobrepondo-o por fim (p. 39). Embora reconheça que em dois terços da obra de Heródoto o antigo ponto de vista

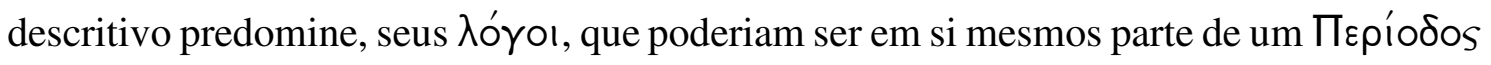
ou de etnografias autônomas, não são tratados sob o ponto de vista descritivo do

\footnotetext{
${ }^{20}$ O termo pode ser traduzido por "história contemporânea", mas optamos por utilizá-lo em alemão, pois os estudiosos posteriores a Jacoby assim o fazem quando tratam do gênero em questão.
} 
$\Pi \varepsilon \rho ı \operatorname{lov}_{\varepsilon ı} \nu$, mas sob o ponto de vista histórico da oposição entre oriente e ocidente (p. 40). Todavia, a introdução do pensamento, do ponto de vista histórico não é o suficiente: o passo decisivo de Heródoto é tomar o ponto de vista dos gregos a partir do livro VII, na exposição acerca das Guerras Médicas; criou, assim, a monografia histórica, a exposição de um acontecimento particular da história grega em razão de seu significado histórico (p. 41). Nela, portanto, predomina o pensamento histórico, o elemento narrativo - as descrições tornam-se um meio de discurso para a narrativa, em forma de excursos - e o ponto de vista helênico; estes elementos, assim que realizados, não são mais perdidos dentro da historiografia antiga (p. 41).

Finalmente, quando os historiadores posteriores a Heródoto concedem novamente maior espaço para o elemento descritivo-etnográfico na narraativa, a relação da mistura tornou-se diferente daquela presente na etnografia; agora, o elemento geográficoetnográfico traz, na historiografia, o caráter de "ciência auxiliar" ou de elemento artísticonovelístico, ingrediente utilizado para o entretenimento do leitor (pp. 41-2). A partir deste momento, é preservada a consciência de que etnografia descritiva e a história são coisas diferentes e de que uma ênfase demasiadamente forte no elemento descritivo danifica o caráter genérico da história (p. 42).

A partir destas considerações de Jacoby, Karl Trüdinger apresentou, em 1918, seu trabalho chamado Studien zur Geschichte der grieschisch-römischen Ethlographie [Estudo sobre a história da etnografia greco-romana], no qual procura traçar a história deste gênero etnográfico antigo, dando atenção também à forma que assumiu nas letras latinas.

Segundo Trüdinger, a tradição etnográfica seria multifacetada, e para dar conta desta diversidade em sua manifestação, elaborou subgrupos para classificar as formas com que esta tradição aparece entre os antigos. Ele propõe os seguintes grupos de trabalhos etnográficos: a) as descrições universais de povos e lugares; b) os periploi; c) as monografias etnográficas; e d) as digressões etnográficas (p. 5). Em sua análise, o autor privilegia os dois últimos grupos.

Trüdinger identifica a Jônia como o berço da escrita etnográfica. Segue Jacoby e coloca Hecateu de Mileto como o primeiro a resumir todo o conhecimento jônico acerca

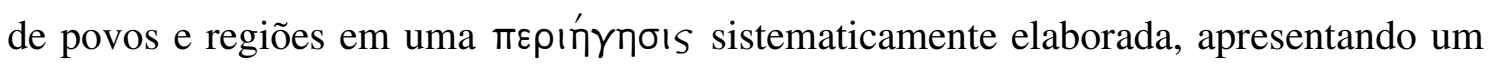
esquema da matéria que se encontra no texto do milésio: inicia com a descrição da costa, em forma de periploi, apontando para portos, cidades, rios e montanhas ao redor dela; depois, se volta ao interior, nomeando cidades, lagos e montanhas, observando a 
particularidade da vegetação; discorre acerca da fertilidade das terras e da fauna; faz observações sobre a singularidade dos habitantes, sobretudo de seu vestuário, sobre seu modo de vida - se nômades ou sedentários -, sobre seus hábitos alimentares (pp. 9-10). Ou seja, os тómoı fundamentais do gênero se encontram já em Hecateu.

Todavia, o autor sublinha que, possivelmente, textos que continham tais informações, ou seja, texto de literatura etnográfica, já circulavam pela região antes mesmo de Hecateu (p. 14).

Trüdinger passa então para a análise dos livros etnográficos de Heródoto, a quem

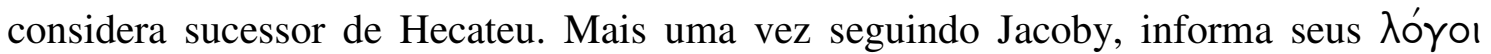
etnográficos, ou seja, os relatos acerca dos egípcios, assírios, citas etc., seguem este esquema quadripartite: a) relato acerca da terra; b) da sua história; c) dos vómoı dos

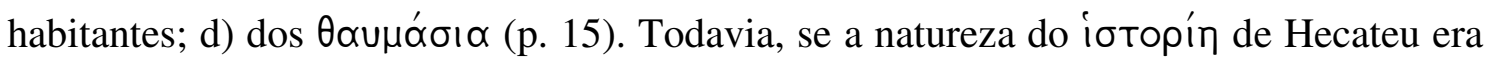

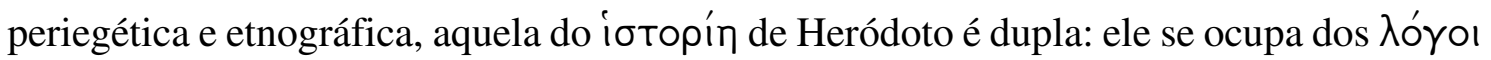
etnográficos, mas seu enfoque principal é a guerra entre gregos e persas. Assim, as passagens etnográficas aparecem na forma de excursos apenas parcialmente conectados à narrativa histórica (p. 16).

Após análise das digressões, propõe um esquema cujos tómoı formariam uma monografia herodoteana ideal (p. 21):

\begin{tabular}{|c|c|c|}
\hline 1. A terra. & 2. O povo. & $\begin{array}{l}\text { 3. As maravilhas da terra } \\
\left(\theta \propto \cup \mu \alpha \sigma^{\prime} \alpha\right) \text {. }\end{array}$ \\
\hline $\begin{array}{l}\text { a) Fronteira, panorama, } \\
\text { forma. }\end{array}$ & a) Número. & \\
\hline b) Natureza da terra. & $\begin{array}{l}\text { b) Antepassados, } \\
\text { Arqueologia. }\end{array}$ & \\
\hline c) Rios. & c) Estilo de vida. & \\
\hline d) Clima. & d) Costumes. & \\
\hline e) Fauna. & & \\
\hline
\end{tabular}

Propõe também que a descrição dos costumes nas três grandes etnografias de Heródoto - dos egípcios, persas e citas - segue um esquema rígido que se inicia com o detalhamento dos costumes religiosos e finda com os pormenores dos seu ritos funerários, 


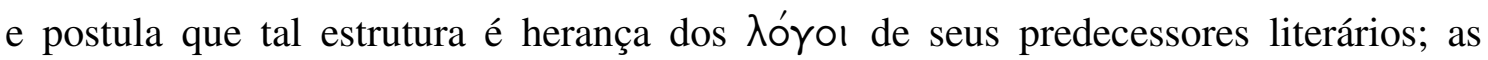
digressões menores têm, todavia, sequência mais livre (p. 26).

Com Heródoto, teria surgido também uma nova forma de literatura, que é a literatura paradoxo-etnográfica, que coloca, antiteticamente, as particularidades do Norte e do Sul do mundo conhecido, no que toca à sua natureza e também aos seus povos (p. 36). Esta comparação antitética é baseada na relação entre uma população e o meio natural em que vive, a qual já era corrente em trabalhos que circulavam pela Jônia, como por

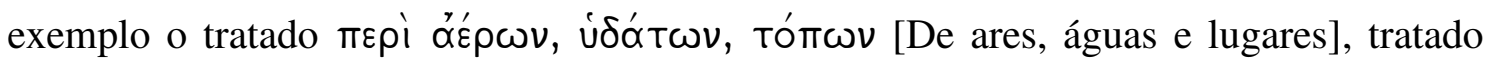
atribuído a Hipócrates (p. 37).

Neste tratado, se apresenta a teoria que divide Ásia e Europa de acordo com natureza e clima - esta, de topografia variada e selvagem e sujeita a grandes e severas variações climáticas, aquela, de terra fértil em e clima ameno, no qual prevalece

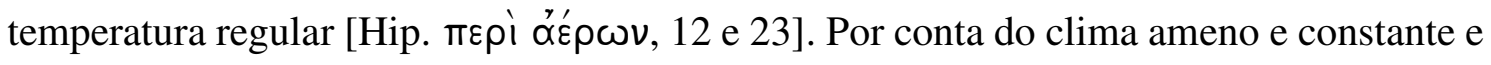
da terra agradável, os asiáticos não são muito variados na aparência e são menos corajosos

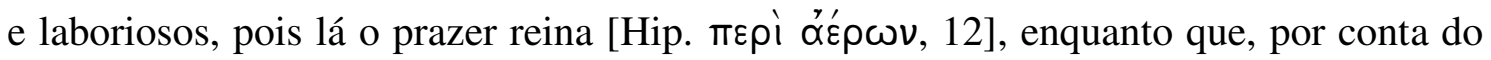
clima severo e mutável, os europeus diferem mais em aparência e são mais propensos ao

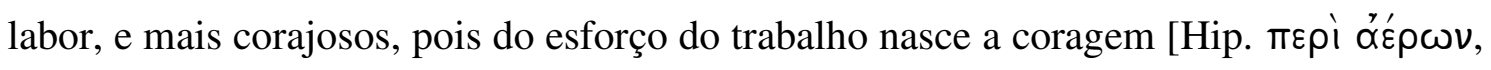
12]. Segundo Trüdinger, estas considerações são fundamentais na fundamentação descritiva da etnografia jônica (p. 41).

Estas seriam, pois, as características fundamentais da etnografia jônica.

A partir do século IV a. C., teria havido uma nova orientação na descrição

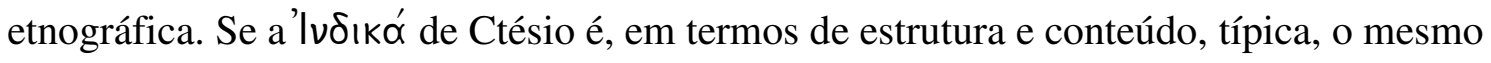
não se poderia dizer sobre trabalhos como os de Dinão e Heracleides de Cuma, ambos

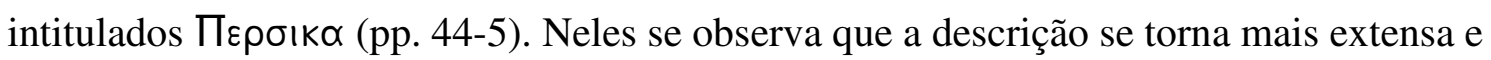
minuciosa; maior é o interesse na ßíos dos grandes reis, na vida da corte e na enumeração dos vónoı, menor a curiosidade sobre as maravilhas relacionadas à população (pp. 45-6). Ademais, Trüdinger identifica mais três pontos que são importantes para a compreensão do gênero neste período: a fundação de uma observação de povos historicamente orientada; o desenvolvimento das teorias que relacionam povo e natureza; e o progresso no reconhecimento da individualidade dos povos estrangeiros (p. 48).

Todavia, em Teopompo, importante historiador do século IV a. C., percebe-se maior ligação com a antiga etnografia jônica do que com a descrição de povos praticada por seus contemporâneos (p. 63). 
$\mathrm{Na}$ linha histórica traçada pelo autor, os próximos são os historiadores do período helenístico. Assim como no século $\mathrm{V}$ a. C., neste momento temos o movimento fundamental para o início da produção etnográfica, que foi desbravamento de novos territórios pelos jônios e seu consequente contato com novos povos e tribos durante as campanhas de Alexandre, o Grande, na Ásia, as quais abrem novos horizontes geográficos aos gregos e que, por sua vez, também incentivam a produção de novas etnografias (p. $64)$.

Os trabalhos - que nos chegaram em forma fragmentada - de historiadores do período alexandrino como Nearco, Onesícrito e Clitarco, teriam apresentado algumas características novas em relação à etnografia de estilo jônico: além de os historiadores serem testemunhas oculares do que escrevem e descrevem, pois participantes das campanhas, suas digressões etnográficas, pequenas ou grandes, são incluídas de forma orgânica na narrativa histórica, ao contrário do que ocorria nos excursos jônicos, que eram inseridos de modo abrupto na narrativa principal (p. 65). Mas, mais importante, o tratamento da matéria se torna mais diversificado quanto uso dos тómoı próprios da etnografia jônica, uso este que varia de autor para autor, o que mostraria a ausência de um esquema rígido na composição e ordenação dos mesmos, ao contrário do que acontece na descrição etnográfica jônica (pp. 77-80).

Trüdinger aponta, também, que outro historiador do período, Megástenes, mostra de forma mais contundente a nova orientação da descrição daquele momento, quando descreve a ßíos dos reis e detalha a estrutura social e os mecanismos de governo e administração (p. 80).

Continuando, o autor passa para uma longa análise das digressões etnográficas nas obras de Posidônio (ca. 135 a. C. - 51 a. C.), a partir dos fragmentos de suas Histórias, e conclui que estas digressões são idênticas em estilo, em tipo de descrição e em estrutura àquelas dos predecessores já estudados, assim como o seu escopo, o que lhe faz afirmar que Posidônio não trilhou nenhum caminho particularmente novo nesse sentido (p. 117). Algo parecido ocorre em relação ao conteúdo dos excursos: sua forma sistematicamente

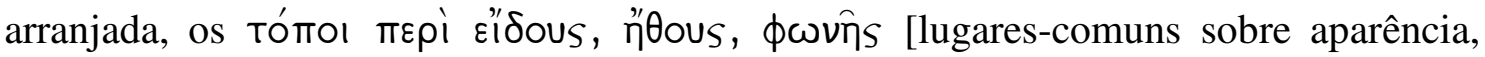
caráter, idioma], a ênfase no que é singular e exótico, a relação entre natureza e povo, o interesse filológico sobre nomes, isto tudo já pode ser observado em Heródoto ou nos historiadores alexandrinos (pp. 117-8). Ainda assim, o autor enxerga algumas particularidades no método de Posidônio: se concentra em especial nas particularidades físicas e de caráter dos povos e na relação destas características físicas e anímicas com a 
natureza do meio onde vivem, relação esta explorada mais profundamente por Posidônio que por outros autores, e dá muita atenção às singularidades de cada povo ou tribo, explorando-as em maior detalhe do que era comum, além do interesse na tópica dos armamentos e práticas de guerra (p. 103-7).

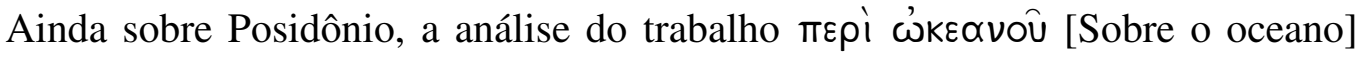
revela outro aspecto importante de seu método: a tentativa de determinar o agrupamento original dos povos (p. 123).

Este método de descrição etnográfica de Posidônio é importante pois teve impacto nas digressões de historiadores romanos como Salústio e Pompeu Trogo, que o teriam tido como modelo (p. 127).

Podemos dizer que estas são as características principais do desenvolvimento do gênero etnográfico antigo segundo Trüdinger. Por fim, sua última grande contribuição que deve ser mencionada aqui é a sistematização e o elenco dos lugares-comuns típicos do gênero: a) o da origo (autoctonia, miscigenação e genealogia); b) definição e derivação do nome dos povos; c) número de povos; d) aparência física; e) armamento e práticas de guerra; f) vestuário; g) habitação; h) modo de vida, alimentação, bebida, costumes ligados ao comer e beber; i) regime (organização política); j) deuses; k) sacrifícios; 1) divinação; m) juramentos e alianças; n) matrimônio e vida do homem e da mulher; o) procedimentos funerários; p) caráter do povo; r) indagação sobre a singularidade dos costumes; s) paradoxografia; t) teorias climáticas (p. 175).

Tendo estudado os textos fundamentais de Jacoby e Trüdinger, delineamos as características principais do gênero etnográfico antigo, já que todos os autores posteriores que se preocuparam com este gênero partem da fundamentação destes dois. Entretanto, há ainda alguns acréscimos a serem feitos. Norden ${ }^{21}$ aponta a origem do interesse etnográfico para além de Hecateu, em Homero, ideia acompanhada por Müller ${ }^{22}$, por exemplo. Thomas ${ }^{23}$ atesta a existência de uma tradição etnográfica a partir do uso dos lugares-comuns do gênero por poetas romanos como Virgílio e Lucano, sublinhando que a Germania foi o primeiro estudo inteiramente dedicado a este gênero, pois até então as etnografias operavam como aetia para tópicos mais centrais ${ }^{24}$.

\footnotetext{
${ }^{21}$ E. Norden (1998, pp. 13-7). Primeira edição publicada em 1920.

${ }^{22}$ K. E. Müller (1997). Primeira edição publicada em 1970.

${ }^{23}$ R. F. Thomas (1982).

${ }^{24} \operatorname{Idem}($ p. 5).
} 
Outro ponto explorado por estudiosos é a relação do gênero etnográfico com o historiográfico. Vimos que Jacoby entendia a etnografia como um estágio dentro do desenvolvimento da historiografia antiga, mas esta relação foi pouco explorada pelos comentadores de Tácito ou pelos scholars que se dedicaram ao estudo tanto de um quanto de outro. Dench afirma que, apesar do material etnográfico presente, por exemplo, em Heródoto, ser identificado por um leitor moderno como próximo à geografia ou antropologia, este material era, na antiguidade, envolto em práticas retóricas que eram entendidas como essencialmente históricas ${ }^{25}$. Por outro lado, Fornara diz que as convenções da etnografia diferem daquelas da história: enquanto esta obedece às leis da evidência e obediência à verdade, aquela permite a publicação de dados não confirmados ou mesmo improváveis ${ }^{26}$; diz, também, que as duas se diferem pelo fato da etnografia ser apenas coleta e apresentação de dados, quanto que a história é mimética ${ }^{27}$.

A questão sobre a relação entre etnografia e historiografia é crucial para a argumentação do nosso trabalho, e em breve voltaremos à discussão com maior profundidade. Antes, porém, julgamos necessário estudar o texto de Tácito como uma monografia etnográfica em detalhes, pois é desta forma que ele é quase que universalmente entendido.

\subsection{A Germania como monografia etnográfica}

Afirmamos, mais de uma vez, que a Germania é amplamente entendida e considerada como uma monografia etnográfica. Pretendemos, pois, neste subcapítulo, apresentar um olhar mais aprofundado sobre a Germania como uma monografia etnográfica, identificando claramente as características ditas do gênero no texto, bem com os topoi etnográficos já mencionados.

Quanto à Germania ser um monografia, não há dúvidas. Embora uma das particularidades do texto seja a ausência de um prólogo onde o autor afirma a matéria a ser tratada, uma análise da obra e o título a ela atribuída nos revela uma clara unidade temática: Tácito escreve de origine et situ germanorum, sobre a origem e o sítio dos germanos. Não há em seu opúsculo nada além de considerações sobre a Germânia como espaço físico e sobre seus habitantes, o que configura, claramente, uma unidade de res.

\footnotetext{
${ }^{25}$ E. Dench (2007, p. 493).

${ }^{26}$ C. W. Fornara (1983, p. 15).

${ }^{27}$ Idem (p. 29).
} 
Como já vimos no subcapítulo anterior, a etnografia trata, fundamentamente, em seus primeiros passos ainda na Jônia, da descrição das regiões e nações da sucessão genealógica da realeza, das maravilhas do local e dos costumes. No caso da Germania, o texto se concentra na descrição da terra e na distribuição das tribos por ela, e, principalmente, nos mores das populações germânicas. Isto pode ser constatado pela ausência de uma genealogia real no texto e por pouquíssimas passagens que tratam de maravilhas. Agora, passagens acerca da região e dos costumes constituem o âmago do texto. Provavelmente, este enfoque é influência das etnografias de Posidônio, que, como vimos a partir da análise de Trüdinger, estava mais interessado na relação entre lugar e costumes, e que foi o maior modelo para as descrições de povos entre os romanos.

Vimos também que Jacoby menciona que há apenas etnografias de povos politicamente independentes. Este é, evidentemente, o caso da Germânia, afinal, a maior parte de seu território não nunca havia sido conquistada, e suas tribos já haviam infringido pesadas derrotas militares a Roma.

No mais, sabemos que a etnográfica é um gênero descritivo. Hoje, entende-se descrição como uma explicação do que se observa, sendo estática e desprovida de ação. De acordo com este entendimento, a Germania é claramente descritiva, pois se ocupa de definição de paisagens e do elenco de costumes, não de ações e acontecimentos, como a narrativa.

Os lugares-comuns etnográficos elencados por Trüdinger podem também ser facilmente identificados no texto. Observemos um por um:

Origo (autoctonia, miscigenação e genealogia):

Ipsos Germanos indigenas crediderim minimeque aliarum gentium adventibus et hospitiis mixtos [...] [II, 1]

Os próprios germanos são autóctones, creio, e pouco misturados por imigrações de outras gentes e hospedagens [...]. [II, 1$]^{28}$

Celebrant carminibus antiquis, quod unum apud illos memoriae et annalium genus est, Tuistonem deum terra editum. ei filium Mannum originem gentis conditoresque Manno tres filios adsignant, e quorum

\footnotetext{
${ }^{28}$ A tradução dos trechos da Germania é nossa.
} 
nominibus proximi Oceano Ingaevones, medii Herminones, ceteri Istaevones vocentur. [II, 3]

Celebram em canções antigas, que é o único gênero de registro e anais entre eles, o deus Tuistão, nascido da terra. A ele atribuem filho, Mano, origem da gente, e três filhos a Mano, seus fundadores, de cujos nomes chamam-se ingevões próximos ao Oceano, herminões ao centro, istevões os restantes. [II, 3]

Definição e derivação do nome dos povos:

4. quidam, ut in licentia vetustatis, plures deo ortos pluresque gentis appellationes, Marsos Gambrivios Suebos Vandilios adfirmant, eaque vera et antiqua nomina. 5 . ceterum Germaniae vocabulum recens et nuper additum, quoniam qui primi Rhenum transgressi Gallos expulerint ac nunc Tungri, tunc Germani vocati sint: ita nationis nomen, non gentis, evaluisse paulatim, ut omnes primum a victore ob metum, mox et a se ipsis invento nomine Germani vocarentur. [II, 45]

Alguns afirmam, como que por permissão da antiguidade, ao deus mais descendentes e mais denominações de gente - marsos, gambrívios, suevos, vandílios - e que tais são nomes verdadeiros e antigos; 5 . ademais, que o termo Germânia é recente e há pouco aplicado, porquanto os primeiros que atravessaram o Reno expulsaram os galos e chamam-se agora tungros, antes germanos; assim, que paulatinamente prevaleceu nome de nação, não da gente, de modo que todos foram chamados pelo nome inventado, germano, primeiro pelo vitorioso em razão do medo, depois por si mesmos. [II, 4-5]

Número de povos:

ei filium Mannum originem gentis conditoresque Manno tres filios adsignant, e quorum nominibus proximi Oceano Ingaevones, medii Herminones, ceteri Istaevones vocentur. [II, 3] 
A ele [Tuistão] atribuem filho, Mano, origem da gente, e três filhos a Mano, seus fundadores, de cujos nomes chamam-se ingevões próximos ao Oceano, herminões ao centro, istevões os restantes. [II, 3]

Aparência física:

[...] unde habitus quoque corporum, tamquam in tanto hominum numero, idem omnibus: truces et caerulei oculi, rutilae comae, magna corpora et tantum ad impetum valida. [IV, 2]

[...] daí também a aparência dos corpos, tão quanto em tamanho número de pessoas, a mesma em todos: olhos ferozes e azuis, cabeleira louro-avermelhada, corpos grandes e robustos somente para o ataque [...]. [IV, 2]

Armamento e práticas de guerra:

$\mathrm{Ne}$ ferrum quidem superest, sicut ex genere telorum colligitur. rari gladiis aut maioribus lanceis utuntur: hastas vel ipsorum vocabulo frameas gerunt angusto et brevi ferro, sed ita acri et ad usum habili, ut eodem telo, prout ratio poscit, vel comminus vel eminus pugnent [VI, 1]

Raros empregam gládios ou lanças longas; carregam hastas ou, no termo deles, frâmeas, de ponta estreita e curta, mas tão aguda e adequada ao uso que combatem, no corpo a corpo ou à distância, conforme demanda o caso, com a mesma arma. [VI, 1]

in universum aestimanti plus penes peditem roboris; eoque mixti proeliantur, apta et congruente ad equestrem pugnam velocitate peditum, quos ex omni iuventute delectos ante aciem locant. [VI, 4]

Considerando o todo, mais força na infantaria, e por isso pelejam misturados, adequada e adaptada ao combate equestre a velocidade dos infantes, os quais, escolhidos dentre toda juventude, alocam ante a linha. [VI, 4] 
Vestuário:

nec alius feminis quam viris habitus, nisi quod feminae saepius lineis amictibus velantur eosque purpura variant, partemque vestitus superioris in manicas non extendunt, nudae brachia ac lacertos; sed et proxima pars pectoris patet. [XVII, 3]

E não é outra a aparência das mulheres àquela dos homens, senão que as mulheres se cobrem, mais frequentemente, com mantos de linho e os diversificam com púrpura, e não estendem a parte superior do vestido em mangas, nus braços e antebraços; ora, também parte próxima do peito aparece. [XVII, 3]

Habitação:

vicos locant non in nostrum morem conexis et cohaerentibus aedificiis: suam quisque domum spatio circumdat, sive adversus casus ignis remedium sive inscitia aedificandi. [XVI, 2]

Arranjam vilas não ao nosso costume, com construções contíguas e interligadas: cada um circunda sua casa com espaço livre, seja por precaução contra incêndio, seja por inabilidade em edificar. [XVI, 2]

Modo de vida, alimentação, bebida, costumes ligados ao comer e beber:

Potui humor ex hordeo aut frumento, in quandam similitudinem vini corruptus; proximi ripae et vinum mercantur. cibi simplices, agrestia poma, recens fera aut lac concretum [...]. [XXIII, 1]

Para beber, líquido da cevada ou trigo, fermentado à certa semelhança do vinho; os próximos à margem comerciam também o vinho. Os alimentos são frugais, frutos silvestres, caça fresca ou leite coalhado. [XXIII, 1]

Regime (organização política): 
Reges ex nobilitate, duces ex virtute sumunt. nec regibus infinita ac libera potestas [...] [VII, 1]

Tomam reis consoante nobreza, generais consoante virtude; nem mesmo aos reis poder ilimitado e irrestrito [...]. [VII, 1]

\section{Deuses e sacrifícios:}

Deorum maxime Mercurium colunt, cui certis diebus humanis quoque hostiis litare fas habent. Herculem ac Martem concessis animalibus placant. [IX, 1]

Dentre os deuses, cultuam sobretudo Mercúrio, ao qual, em determinados dias, têm por justo sacrificar também vítimas humanas. Aplacam Hércules e Marte com animais permitidos. [IX, 1]

Divinação:

Auspicia sortesque ut qui maxime observant. sortium consuetudo simplex. virgam frugiferae arbori decisam in surculos amputant eosque notis quibusdam discretos super candidam vestem temere ac fortuito spargunt. $[\mathrm{X}, 1]$

Observam, como os que mais o fazem, auspícios e sortes. A prática das sortes é simples. Ramo de árvore frutífera podado, cortam-no em pedaços, e, distinguidos por certos sinais, espargem-nos, fortuitamente e ao acaso, sobre veste branca [...]. [X, 1]

Juramentos e alianças:

iam vero infame in omnem vitam ac probrosum superstitem principi suo ex acie recessisse: illum defendere, tueri, sua quoque fortia facta gloriae eius adsignare praecipuum sacramentum est: principes pro victoria pugnant, comites pro principe. [XIV, 1] 
Além disso, infâmia por toda vida e opróbrio ter se retirado da linha, sobrevivente ao seu chefe; defendê-lo, protegê-lo, destinar seus valorosos feitos à glória dele é o principal juramento: líderes lutam pela vitória, companheiros lutam pelo líder. [XIV, 1]

Matrimônio e vida do homem e da mulher:

Quamquam severa illic matrimonia, nec ullam morum partem magis laudaveris. nam prope soli barbarorum singulis uxoribus contenti sunt, exceptis admodum paucis, qui non libidine sed ob nobilitatem plurimis nuptiis ambiuntur. [XVIII, 1]

Entretanto, matrimônio lá é rigoroso, e nenhum aspecto de seus costumes elogiar-se-ia mais; pois são praticamente os únicos, dentre os bárbaros, contentes com uma esposa, excetuados mui poucos que, não por desejo mas por nobreza, são cobiçados por muitos casamentos. [XVIII, 1]

ne se mulier extra virtutum cogitationes extraque bellorum casus putet, ipsis incipientis matrimonii auspiciis admonetur venire se laborum periculorumque sociam, idem in pace, idem in proelio passuram ausuramque: hoc iuncti boves, hoc paratus equus, hoc data arma denuntiant. [XVIII, 4]

Para que a mulher não se considere além das aspirações de valor e além dos acasos das guerras, é lembrada, pelos próprios preâmbulos do matrimônio a se iniciar, que ela se torna companheira nos labores e perigos, e tolerará e empreenderá o mesmo na paz, o mesmo na peleja: isto os bois jungidos, isto o cavalo preparado, isto a arma dada denunciam. [XVIII, 4]

Procedimentos funerários:

Funerum nulla ambitio: id solum observatur ut corpora clarorum virorum certis lignis crementur. [XXVII, 1] 
Nos funerais nenhuma pompa: observa-se apenas isso, que os corpos dos homens preclaros sejam cremados com determinada lenha. [XXVII, 1]

Caráter do povo:

Quotiens bella non ineunt, non multum venatibus, plus per otium transigunt, dediti somno ciboque: fortissimus quisque ac bellicosissimus nihil agens, delegata domus et penatium et agrorum cura feminis senibusque et infirmissimo cuique ex familia, ipsi hebent, mira diversitate naturae, cum idem homines sic ament inertiam et oderint quietem. $[\mathrm{XV}, 1]$

Sempre que não entram em guerras, não gastam muito tempo com caçadas, mais com ócio, entregues a sono e comida; aqueles mais fortes e belicosos nada fazem, administração de casa, lar e campos delegada às mulheres e velhos e àquele mais infirme da família; eles mesmos vadiam, extraordinária sua inconstância de temperamento, visto que ao mesmo tempo os homens assim amam a indolência e odeiam a quietude. $[\mathrm{XV}, 1]$

Paradoxografia:

laboris atque operum non eadem patientia, minimeque sitim aestumque tolerare, frigora atque inediam caelo solove adsueverunt. $[\mathrm{IV}, 3]$

[...] ao labor e exercício tolerância outra, e pouco se habituaram a suportar sede e calor; frio e fome, sim, por clima ou solo. [XLV, 1]

Apesar de não termos conseguido identificar no texto os topoi da indagação sobre a singularidade dos costumes ou das teorias climáticas, parece claro que Tácito tinha consciência dos lugares-comuns típicos utilizados na descrição de povos. Como exporemos adiante, acreditamos que falar sobre um gênero etnográfico antigo apresenta alguns problemas; é certo, todavia, de que havia, no momento em que Tácito escreveu, certos pressupostos utilizados na descrição de povos estrangeiros. Agora, a natureza 
destes pressupostos, bem como a natureza do gênero ao qual pertence o texto de Tácito e outras descrições ditas etnográficas, estas observaremos mais atentamente a seguir.

\subsection{Problemas do estabelecimento do gênero etnográfico antigo e a Germania como monografia histórica}

Ao denominar "etnografias" os trabalhos de cunho etno-geográfico de uma única região, Jacoby reconhece que este termo não tem origem antiga, que a terminologia para áreas historiográficas não era suficientemente formada no período e que a íotopín de povos helênicos e bárbaros não se diferenciava muito entre $\mathrm{si}^{29}$. Rives acredita que a inexistência de um termo antigo para designar o que chamamos de etnografia, uma alcunha moderna, sugere que ela não era um gênero formalmente reconhecido no mundo antigo, como a poesia épica ou a história, por exemplo ${ }^{30}$.

Desde o primeiro momento que nos ocupamos deste texto, a ideia de classificar a Germania como um texto pertencente a um gênero que parece não existir formalmente no período em que foi produzido nos parece problemática, afinal, o gênero é fruto de uma situação histórica na qual opera o autor ${ }^{31}$. Desta forma, nosso objetivo desde o começo era procurarmos uma possibilidade de classificação do gênero da Germania que se enquadrasse em algum gênero reconhecido pelo antigos.

Para tanto, é necessário refletirmos, primeiramente, sobre a concepção de gênero que Jacoby possuía - pois, como vimos, a classificação dos autores antigos segue o esquema por ele proposto.

Marincola ${ }^{32}$ aponta para cinco características fundamentais do sistema de Jacoby: 1) adotação de uma noção teleológica do desenvolvimento da história, que teria se iniciado com Hecateu, passado por Heródoto, até assumir a sua forma mais perfeita na monografia de guerra de Tucídides; 2) individualização do desenvolvimento da historiografia - por exemplo, a progressão de Heródoto de geógrafo para etnógrafo para então compositor de monografia de guerra como microcosmo do desenvolvimento do gênero e da consciência histórica de todo um povo; 3) a rígidez quanto à estruturação de suas categorias, mesmo que elas não sejam coerentes com crítica e categorias antigas; 4)

\footnotetext{
${ }^{29}$ F. Jacoby (1956, p. 26).

${ }^{30}$ J. B. Rives (1999, p. 12).

${ }^{31}$ L. E. Rossi (1971, p. 70).

32 J. Marincola (1999, p. 290-301).
} 
adotação uma noção geralmente estática do gênero; e 5) a não acomodação de certas obras em suas classificações, que acabam sendo consideradas problemáticas ou violações de gênero por conta da rigidez do seu modo de ordenação.

O pesquisador americano acrescenta que um aspecto importante para a definição e separação dos gêneros no trabalho de Jacoby é a focalização, ou seja, se a obra tem como enfoque a Grécia continental e suas regiões, é Zeitgeschichte; se uma única cidadeestado, horografia; se terra que não é grega, etnografia ${ }^{33}$. Incluiríamos também, como outro elemento relevante no sistema, a dicotomia entre descrição e narração como definidora de gênero e o desenvolvimento da história de texto descritivo (periegese, com Hecateu) a texto narrativo (monografia de guerra, com Tucídides).

À forma de Jacoby entender o gênero, Marincola opõe uma visão que é baseada na teoria de gênero mais recente, que ganhou forma a partir de autores como Tudorov (1981), Dubrow (1982) e, no âmbito das letras clássicas, Conte (1991), e a aplica na reflexão do gênero historiográfico antigo. Deste modo, Marincola propõe que assumir uma uniformidade de tratamento para autores do mesmo gênero é perigoso, pois o gênero não deve ser entendido como um conceito estático, um conjunto fixo de ingredientes e regras, mas como um conceito dinâmico, no qual a inovação modificava formas tradicionais de modo constante ${ }^{34}$. A historiografia seria, portanto, também dinâmica e aberta à inovação, sendo, por isso mesmo, constantemente recriada. Pelling concorda e acrescenta que historia era uma categoria muito vasta e ampla no mundo romano, a qual englobava uma série de expectativas em si mesma ${ }^{35}$.

Esta forma de encarar os gêneros literários, no geral, e a historiografia, em particular, nos parece muito proveitosa. O jogo de inovação com as regras de gênero é claro, por exemplo, para qualquer um que já tenha estudado a poesia do período helenístico, e a visão - algo hegeliana - desenvolvimentista da literatura, pode ser preterida por uma na qual as diversas formas que um gênero assume convivem concomitantemente e de forma pacífica.

No que toca à etnografia, este approach ao gênero e à historiografia abre uma nova possibilidade de interpretá-la. É razoável pensar que o que chamamos de etnografia é uma das formas assumidas pelo gênero historiográfico entre os gregos e os romanos, uma forma dentro da série de expectativas que a noção de historia encerrava. Isto sem

\footnotetext{
33 J. Marincola (1999, p. 295).

${ }^{34}$ Idem (p. 282).

${ }^{35}$ C. Pelling (1999, p. 330).
} 
deixarmos de considerar que, para qualquer que fosse a taxonomia dos gêneros ou subgêneros historiográficos, o papel da Retórica é imperioso, pois, como discurssus que é, a história opera elementos que a constituem como gênero, que docere, mouere e delectare. Ora, o texto historiográfico antigo documenta um agente histórico (auctor) e as marcas de decodificação por seu público (audiens), duplo referencial balizado por regras que sustentam sua produção e recepção; tais regras podem ser indentificadas como preceitos retórico-poéticos que modalizam e normatizam o discurso, tornando-o apto, e portanto eficaz por seu compromisso com um público específico ${ }^{36}$.

Retomando: há outros argumentos que podemos dar para sustentar a possibilidade de ver a etnografia como uma das formas do gênero historiográfico. A questão da dicotomia entre narração e descrição, por exemplo. Para Jacoby, e mesmo para Marincola, esta separação entre as duas formas de escrever é um critério importante na definição do gênero. Pois bem: Genette ${ }^{37}$ argumenta que a oposição entre narração e descrição vem da tradição acadêmica do séc. XIX; que o termo grego diegesis, usualmente entendido como narração, engloba na verdade os dois tipos de representação; que a diferença entre ambas não é semiológica, mas de conteúdo; e que do ponto de vista dos modos da representação, utilizam o mesmo repertório de linguagem. Ele afirma que a diferença mais significativa entre as duas seria que a narração restitui, pela sucessão temporal de seu discurso, a sucessão também temporal dos eventos, enquanto que a descrição modula através da sucessiva representação de objetos simultâneos e justapostos no espaço; isso quer dizer que a narrativa se distingue da descrição pela coincidência temporal com seu objeto, o que, todavia, perde força na literatura escrita. Além do mais, como aponta P. Martins ${ }^{38}$ em sua leitura de Genette, a diegesis não se trata de uma mimesis.

Hansen $^{39}$ é também contrário a esta oposição, afirmando que, linguística e gramaticalmente, não há diferença entre a narração de uma ação e a descrição de um objeto, que esta diferença é retórica e relacionada ao gênero do discurso. Também afirma que, retoricamente, o discurso implica a relação de pressuposição entre a pessoa e a situação em que age, ou o personagem e a cena onde atua, e que essa relação de pressuposição não permite que se faça a oposição entre descrever e narrar ${ }^{40}$.

\footnotetext{
${ }^{36}$ P. Martins (2013, pp. 224-5).

${ }^{37}$ G. Genette (1969, p. 56-61).

${ }^{38}$ P. Martins (2013, p. 224).

${ }^{39}$ J. A. Hansen (2006, p. 90).

${ }^{40}$ Idem.
} 
Isto posto, pode-se dizer que uma separação entre gêneros a partir da dicotomia entre narração e descrição é contrária ao modo como os antigos entendiam a questão. Portanto, ao invés de se considerar as descrições de povos presentes nas obras historiográficas como digressões e excursos que pouco têm a ver com a narrativa principal e que podem ser facilmente dela destacados, seria melhor entender estas passagens descritivas, como propõe Dibbern ${ }^{41}$, como narrativas amplificadas, passagens perfeitamente integradas ao todo narrativo e que servem para caracterizar os personagens e o espaço onde este todo narrativo se desenvolve. Sendo assim, podemos afirmar que, tanto em sua res quanto em sua uerba, o que se convencionou chamar de etnografia está totalmente integrado àquilo que os antigos entendiam por história, o que, por outros meios, já foi apontado tanto por Marincola ${ }^{42}$ quanto por Pelling ${ }^{43}$.

No caso da Germania, é razoável dizer que suas idiossincrasias, como o fato de não possuir prefácio ou de ser a única monografia deste tipo que nos foi legada, características que fazem dela uma obra bastante peculiar dentre o nosso espólio grecolatino, são frutos do jogo que Tácito faz com as regras de gênero, tal como faziam os poetas helenísticos ${ }^{44}$, o que não faz dela uma obra à parte dentro das letras latinas e nem constitui uma violação de gênero. Ela é, na verdade, apenas uma das formas pelas quais o escrever da história em Roma se manifestou.

Ora, ao considerarmos a Germania uma monografia histórica, e não uma monografia etnográfica, novas possibilidades interpretativas surgem no horizonte. Gostaríamos de nos concentrar em uma delas, que parece particularmente promissora.

\subsection{Monografia, história e o gênero demonstrativo da retórica}

Sabemos que o gênero demonstrativo ou epidítico trata do elogio ou da censura de algo ou alguém, e que é de natureza didática.

Rodolpho ${ }^{45}$ define a monografia da seguinte maneira ao tratar da Bella Jugurtha de Salústio, a partir da leitura de Cícero, Ad Familiares, V, 12:

\footnotetext{
${ }^{41}$ C. H. Dibbern (2013, p. 38).

42 J. Marincola (1999, p. 306).

${ }^{43}$ C. Pelling (1999, p. 334).

${ }^{44}$ L. E. Rossi (1971, p. 83).

${ }^{45}$ M. Rodolpho (2012, p. 280).
} 
Retoricamente, a monografia pode então ser considerada como gênero demonstrativo, uma vez que sua função primordial seria deleitar, segundo os preceitos de Cícero acima discutidos. Ao narrar um único evento, expõe os participantes de maior relevância nos acontecimentos de maneira que alguns sejam elogiados e outros vituperados - as obras de Salústio formam retratos que são produtos desse gênero, opondo as figuras virtuosas às viciosas.

Mas não é apenas a monografia que pode ser aproximada do gênero demonstrativo: também a história está ligada a ele.

No De oratore de Cícero, lemos estas palavras proferidas por M. Antônio:

Quis cohortari ad virtutem ardentius, quis a vitiis acrius revocare, quis vituperare improbos asperius, quis laudare bonos ornatius, quis cupiditatem vehementius frangere accusando potest? Quis maerorem levare mitius consolando? Historia vero testis temporum, lux veritatis, vita memoriae, magistra vitae, nuntia vetustatis, qua voce alia, nisi oratoris, immortalitati commendatur? (Cic. De orat., 2, 35-6) ${ }^{46}$

Quem pode incitar à virtude mais ardentemente, fazer recuar os vícios mais severamente, vituperar os ímprobos mais asperamente, louvar os bons mais ornadamente, destruir a a cupidez, acusando, mais veementemente? Quem, consolando, pode aliviar a tristeza mais gentilmente? Em verdade, a história, testemunha dos tempos, luz da verdade, vida da memória, mestra da vida, mensageira dos tempos idos, é recomendada à imortalidade por qual outra voz, senão a do orador?

Vemos aqui a importantíssima conexão entre orator e historia por parte do autor. Ora, vemos aqui que a função do orador é encorajar o que é virtuoso - cohortari ad virtutem - e recriminar os vícios - vitiis revocare; vituperar os ímprobos - vituperare improbos - e elogiar os bons - laudare bonos; abater a cupidez acusando - cupiditatem frangere accusando; aliviar as aflições consolando - maerorem levare consolando.

A história aparece no leque de funções do orador, pois sua voz é a mais adequada para conceder imortalidade à história - qua voce alia, nisi oratoris, immortalitati

\footnotetext{
46 Todas as passagens em latim foram retiradas das edições da LOEB, as quais estão devidamente apontadas na bilbiografia.
} 
commendatur? Desta maneira, sendo o escrever da história métier próprio ao orator, podemos estender as funções deste - exortar a virtude e desencorajar o vício, elogiar o bom e vituperar o ruim - à própria história. Assim, teria ela também o objetivo de elogiar e vituperar, exortar e desencorajar.

Das características atribuídas à história - testis temporum, lux veritatis, vita memoriae, magistra vitae, nuntia vetustatis - nos chama atenção, em especial, que ela é magistra vitae, mestra da vida, o que remete à noção de que a história tem, por ser mestra da vida, função didática, de ensinar, de docere.

Tendo em vista estas atribuições, ou seja, considerando que a história é uma das funções do orador e que tem caráter de exortação moral e didático, ela parece estar vinculada ao tertium genus de oratória discutido pelas personagens nas passagens subsequentes. M. Antônio ${ }^{47}$ argumenta que as funções do orador vão além daquelas definidas em manuais de retórica; ele inclui, ao lado dos gêneros deliberativo e judiciário, o tertium genus, chamado demonstrativo ou epidítico, o qual é de natureza didática e lida com a exortação moral. Antônio não discute as suas regras, pois este gênero não precisaria de regras por ser muito claro. Ambrósio ${ }^{48}$ menciona que a prática, observação e conhecimento do mundo fornecem as regras desse gênero.

A partir destas passagens, pode-se dizer que o discurso histórico recorre ao gênero demonstrativo, que tem função didática e moral, para o elogio ao virtuoso e vitupério ao vicioso.

\subsection{Conclusão}

Vimos, neste capítulo, que a Germania é comumente entendida, quanto ao seu gênero, como uma monografia etnográfica. Analisamos em profundidade o estabelecimento do gênero por estudiosos modernos e aplicamos as suas considerações ao texto de Tácito. Depois, observamos que este estabelecimento da etnografia como gênero é problemático por conta da noção estática de gênero que subjaz a ele, e que seria mais razoável entender a Germania como uma das formas assumidas pelo gênero historiográfico entre os romanos. Dito isto, associamos o gênero historiográfico ao gênero demonstrativo da retórica, pois, embora saibamos que esta associação não é a única que

\footnotetext{
${ }^{47}$ Seguimos aqui o sumário da discussão proposto por R. W. Cape Jr (1997, p. 216).

${ }^{48}$ R. Ambrósio (2002, p. 11)
} 
pode ser feita a partir do momento em que entendemos a Germania como uma monografia histórica, ela nos dá a chance de pensar a construção do êthos germânico no texto tendo em vista as particularidades deste gênero epidítico. É o que faremos no capitulo que se segue. 


\section{A construção do êthos dos germanos}

Até agora, discutimos a Germania tendo como enfoque o seu gênero. Vimos a sua definição como uma monografia etnográfica por parte dos comentadores, o estabelecimento do gênero etnográfico pela crítica moderna, e o que nos permite dizer que o texto Tácito seja, de fato, uma monografia etnográfica. Depois, indicamos alguns problemas que existentes no estabelecimento e na classificação deste gênero etnográfico, e propomos considera-lo uma das variações assumidas pela historiografia, considerando, deste modo, a Germania um texto historiográfico em seu sentido pleno. Por fim, buscamos uma aproximação da historiografia e monografias antigas com o gênero demonstrativo, ou epidítico, da retórica.

Nesse capítulo, teceremos algumas considerações sobre como o êthos das populações germânicas é construído por Tácito naquela que é classificada como a primeira sessão do seu texto, que compreende trecho dos parágrafos I ao XXVII. Nosso estudo seguirá por dois caminhos: primeiramente, analisaremos este êthos como um retrato epidítico, isto é, como um êthos construído a partir de dispositivos retóricos próprios ao gênero demonstrativo; depois, estudaremos a Germania como uma ekphrasis, ou melhor, como um conjunto de ekphraseis.

\subsection{A Germania como um retrato epidítico}

Primeiramente e antes de qualquer análise, é necessário dizer o que entendemos por êthos. Êthos é uma construção intra e extradiscursiva de personagens fictícios ou não ${ }^{49}$. Os elementos intradiscursivos são aqueles que são próprios ao discurso, como por exemplo a utilização dos preceitos conceituados pelos manuais de retórica antiga, enquanto que os elementos extradiscursivos consistem da expectativas da recepção, isto é, dos leitores e ouvintes do texto, e das convenções que são resultado desta recepção, as quais podemos definir como estereótipos. Assim, acreditamos que o caráter dos povos germânicos na obra em questão foi retoricamente construído por Tácito e condicionados por estereótipos correntes acerca dos bárbaros do Norte. Portanto, veremos que este êthos é constituído a partir de preceitos que são próprios ao gênero epidítico ou demonstrativo da retórica, o qual é prescrito em tratados gregos e latinos sobre oratória, e que se

\footnotetext{
${ }^{49} \mathrm{O}$ parágrafo é um resumo da sistematização feita por C. H. Dybbern (2013, pp. 50-62).
} 
relaciona à ideia geral e estereotipada que se tinha acerca dos bárbaros germânicos em Roma.

Já vimos em outra parte que o gênero epidítico ou demonstrativo trata do elogio ou da censura de algo ou alguém, os quais são compostos através de uma tipologia também retoricamente condicionada. Lemos no tratado latino Rhetorica ad Herennium, III. 10:

Nunc ad demonstrativum genus causae transeamus. Quoniam haec causa dividitur in laudem et vituperationem, quibus ex rebus laudem constituerimus, ex contrariis rebus erit vituperatio conparata. Laus igitur potest esse renim externarum, corporis, animi.

Rerum externarum sunt ea quae casu aut fortuna secunda aut adversa accidere possunt: genus, educatio, divitiae, potestates, gloriae, ci vitas, amicitiae, et quae huiusmodi sunt et quae his contraria. Corporis sunt ea quae natura corpori adtribuit commoda aut incommoda: velocitas, vires, dignitas, valetudo, et quae contraria sunt. Animi sunt ea quae consilio et cogitatione nostra constant: prudentia, iustitia, fortitudo, modestia, et quae contraria sunt. Erit igitur haec confirmatio et confutatio nobis in huiusmodi causa.

Passemos agora ao gênero demonstrativo de causa. Já que esta causa é dividida em elogio e vitupério, com os tópicos a partir dos quais construiríamos o elogio, por seus contrários, será apresentado o vitupério. O elogio pode, pois, ser das coisas externas [rerum externarum], do corpo [corporis] e do ânimo [animi]. Nunc ad demonstrativum genus causae transeamus.

Coisas externas são aquelas que podem ocorrer por acaso ou fortuna, favorável ou adversa: ascendência, educação, riqueza, poder, glória, cidadania, amizades, e o que é desta espécie e o seu contrário. Coisas do corpo são aquelas que a natureza atribuiu ao corpo, convenientes ou inconvenientes: rapidez, força, beleza, e o que é seu contrário. Coisas do ânimo são aquelas que consistem de nosso julgamento e pensamento: prudência, justiça, coragem, moderação, e o que é seu contrário. ${ }^{50}$

\footnotetext{
${ }^{50}$ Tradução nossa.
} 
Temos que, na Rhetorica ad Herennium, tanto o elogio quanto o vitupério podem ser feito a partir das coisas externas, que são aquelas que ocorrem de forma fortuita, das coisas do corpo e do ânimo, ou seja, dos atributos de um e de outro.

Hansen $^{51}$ elenca topoi epidíticos que aparecem em outros tratados retóricos latinos, como por exemplo aqueles de Cícero e Quintiliano: nome, natureza, vida, hábito, afetos, feitos, ascendência, nação, pátria, corpo, fortuna, entre outros.

Isto posto, será possível encontrar no texto de Tácito estes lugares-comuns acima listados e divididos nas três categorias (coisas externas, do corpo e do ânimo) para compor o êthos dos germanos?

Sobre as coisas externas, ou res externae, podemos encontrar na Germania a seguinte passagem acerca da ascendência e origem dos germanos:

Celebrant carminibus antiquis, quod unum apud illos memoriae et annalium genus est, Tuistonem deum terra editum. ei filium Mannum originem gentis conditoresque Manno tres filios adsignant, e quorum nominibus proximi Oceano Ingaevones, medii Herminones, ceteri Istaevones vocentur. [II, 3]

Celebram em canções antigas, que são o único gênero de registro e anais entre eles, o deus Tuistão, nascido da terra. A ele atribuem filho, Mano, origem da gente, e três filhos a Mano, seus fundadores, de cujos nomes chamam-se ingevões próximos ao Oceano, herminões ao centro, istevões os restantes. [II, 3]

Temos também trechos acerca de seus nomes:

quidam, ut in licentia vetustatis, plures deo ortos pluresque gentis appellationes, Marsos Gambrivios Suebos Vandilios adfirmant, eaque vera et antiqua nomina. 5. ceterum Germaniae vocabulum recens et nuper additum, quoniam qui primi Rhenum transgressi Gallos expulerint ac nunc Tungri, tunc Germani vocati sint [...]. [II, 4-5]

\footnotetext{
${ }^{51}$ J. A. Hansen (2006, p. 95).
} 
Alguns afirmam, como que por permissão da antiguidade, ao deus mais descendentes e mais denominações de gente - marsos, gambrívios, suevos, vandílios - e que tais são nomes verdadeiros e antigos; 5. ademais, que o termo Germânia é recente e há pouco aplicado, porquanto os primeiros que atravessaram o Reno expulsaram os galos e chamam-se agora tungros, antes germanos [...]. [II, 4-5]

Sobre suas riquezas:

argentum et aurum propitiine an irati dii negaverint dubito. nec tamen adfirmaverim nullam Germaniae venam argentum aurumve gignere: quis enim scrutatus est? 4. possessione et usu haud perinde adficiuntur: est videre apud illos argentea vasa, legatis et principibus eorum muneri data, non in alia vilitate quam quae humo finguntur. [V, 3-4]

Prata e ouro negaram-lhes os deuses - se por favor ou irados, não o sei. Todavia, não afirmaria que nenhuma veia da Germânia engendra prata ou ouro: quem, de fato, explorou-a? 4. Não são influenciados por sua posse e uso igualmente. Vê-se entre eles aparatos de prata, dados como presente aos embaixadores e comandantes deles, a não outro baixo preço que o quê se molda do chão. [V, 3-4]

Quanto a seus hábitos e costumes, os quais podemos também atribuir às coisas externas, encontramos muitos exemplos por todo o texto. Tácito nos fornece um relato sobre seu sistema político:

Reges ex nobilitate, duces ex virtute sumunt. nec regibus infinita ac libera potestas [...]. [VII, 1]

Tomam reis consoante nobreza, generais consoante virtude; nem mesmo aos reis poder ilimitado e irrestrito [...]. [VII, 1]

Sua religião: 
Deorum maxime Mercurium colunt, cui certis diebus humanis quoque hostiis litare fas habent. Herculem ac Martem concessis animalibus placant. [IX, 1]

Dentre os deuses, cultuam sobretudo Mercúrio, ao qual, em determinados dias, têm por justo sacrificar também vítimas humanas. Aplacam Hércules e Marte com animais permitidos. [IX, 1]

Seus costumes matrimoniais:

Quamquam severa illic matrimonia, nec ullam morum partem magis laudaveris. nam prope soli barbarorum singulis uxoribus contenti sunt, exceptis admodum paucis, qui non libidine sed ob nobilitatem plurimis nuptiis ambiuntur. 2. dotem non uxor marito, sed uxori maritus offert. intersunt parentes et propinqui ac munera probant, munera non ad delicias muliebres quaesita nec quibus nova nupta comatur, sed boves et frenatum equum et scutum cum framea gladioque. [XVIII, 1-2]

Entretanto, matrimônio lá é rigoroso, e nenhum aspecto de seus costumes elogiar-se-ia mais; pois são praticamente os únicos, dentre os bárbaros, contentes com uma esposa, excetuados mui poucos que, não por desejo mas por nobreza, são cobiçados por muitos casamentos. 2. Dote não oferece esposa ao marido, mas à esposa marido. Interpõem-se pais e parentes e apreciam os presentes, presentes requeridos não para mimos femininos, nem com eles se adorna a nova noiva, mas bois e cavalo bridado e escudo com frâmea e gládio. [XVIII, 1-2]

Exemplos de seus hábitos e costumes poderiam ser elencados à exaustão. Para não nos alongarmos em demasia, passemos aos excertos que tratam da coisas do corpo, ou res corpori. Encontramos os seguintes exemplos sobre sua aparência e força:

unde habitus quoque corporum, tamquam in tanto hominum numero, idem omnibus: truces et caerulei oculi, rutilae comae, magna corpora et tantum ad impetum valida. 3. laboris atque operum non eadem 
patientia, minimeque sitim aestumque tolerare, frigora atque inediam caelo solove adsueverunt. [IV, 2-3]

[...] daí também a aparência dos corpos, tão quanto em tamanho número de pessoas, a mesma em todos: olhos ferozes e azuis, cabeleira louro-avermelhada, corpos grandes e robustos somente para o ataque; 3. ao labor e exercício tolerância outra, e pouco se habituaram a suportar sede e calor; frio e fome, sim, por clima ou solo. [IV, 2-3]

E sobre as suas vestimentas:

Tegumen omnibus sagum fibula aut, si desit, spina consertum: cetera intecti totos dies iuxta focum atque ignem agunt. locupletissimi veste distinguuntur non fluitante, sicut Sarmatae ac Parthi, sed stricta et singulos artus exprimente. [XVII, 1]

Vestimenta de todos, sago preso com broche ou, se este falta, osso; por outro lado, passam dias inteiros junto da lareira e fogo, descobertos. Os mais ricos distinguem-se não por veste larga como a do sármata e parto, mas justa e moldando cada membro. [XVII, 1]

Relatos que dizem respeito às coisas do ânimo, ou res animi, são também copiosos na Germania. Lemos sobre o amor dos germanos por sua liberdade:

[...] quippe regno Arsacis acrior est Germanorum libertas. [XXXVII, 3]

[...] sem dúvida mais enérgica que o reino de Arsace é a liberdade dos germanos. [XXXVII, 3]

E sobre o vício que advem desta liberdade:

illud ex libertate vitium, quod non simul nec ut iussi conveniunt, sed et alter et tertius dies cunctatione coeuntium absumitur. [XI, 3] 
Da liberdade este vício, pois não se reúnem ao mesmo tempo nem como ordenados, mas são consumidos dois ou três dias pela demora dos participantes. [XI, 3]

Tácito menciona, como já lemos pouco acima, que os germanos são um povo moderado quanto às mulheres e o matrimônio:

Quamquam severa illic matrimonia, nec ullam morum partem magis laudaveris. nam prope soli barbarorum singulis uxoribus contenti sunt [...]. [XVIII, 1]

Entretanto, matrimônio lá é rigoroso, e nenhum aspecto de seus costumes elogiar-se-ia mais; pois são praticamente os únicos, dentre os bárbaros, contentes com uma esposa [...]. [XVIII, 1]

Mas que, em se tratando de bebida, a situação muda um pouco:

[...] sine apparatu, sine blandimentis expellunt famem. adversus sitim non eadem temperantia. 2. si indulseris ebrietati suggerendo quantum concupiscunt, haud minus facile vitiis quam armis vincentur. [XXIII, $1-2]$

Afastam a fome sem aparato, sem condimentos; contra a sede, temperança outra. Se fores complacente com sua embriaguez, fornecendo o quanto desejam, serão vencidos mais facilmente pelos vícios que por armas. [XXIII, 1-2]

Têm coragem e estima por ela:

Reges ex nobilitate, duces ex virtute sumunt. nec regibus infinita ac libera potestas, et duces exemplo potius quam imperio, si prompti, si conspicui, si ante aciem agant, admiratione praesunt. [VII, 1]

Tomam reis consoante nobreza, generais consoante virtude; nem mesmo aos reis poder ilimitado e irrestrito, e os generais comandam 
por exemplo mais que autoridade, por admiração, se dispostos, se visíveis, se lideram ante a linha. [VII, 1]

Mas tal coragem pode levar a um gosto excessivo pelo conflito:

nec arare terram aut expectare annum tam facile persuaseris quam vocare hostem et vulnera mereri; pigrum quin immo et iners videtur sudore adquirere quod possis sanguine parare. [XIV, 4]

Nem a arar terra nem a expectar colheita anual se persuadi-los-ia tão facilmente quanto a provocar inimigo e ganhar feridas; parece-lhes, sim, indolência e preguiça adquirir com suor o que se pode obter com sangue. [XIV, 4]

Ora, o leitor mais atento deve ter notado que os excertos utilizados acima para demonstrar que a construção do êthos das populações germânicas tem como base topoi epidíticos retoricamente prescritos, como vimos no excerto da Rhetorica ad Herennium, e que são análogos àqueles usados anteriormente para ilustrar os topoi etnográficos, fato este que não é mera coincidência ou Wille zur Repetition por parte deste que lhes escreve. Nos parece que estes topoi epidíticos são muito próximos, para não dizer idênticos, àqueles lugares-comuns identificados pelos estudiosos modernos como próprios ao gênero etnográfico e que vimos com atenção em capítulo anterior. De fato, às coisas externas podemos relacionar os lugares-comuns etnográficos da origo, da definição e derivação do nome dos povos, e todos aqueles que entram na categoria de hábitos e costumes, como por exemplo os armamentos e práticas de guerra, vestuário, habitação, modo de vida, alimentação, bebida, costumes ligados ao comer e beber, deuses, sacrifícios, divinação, juramentos e alianças, matrimônio e vida do homem e da mulher, procedimentos funerários, etc. Às coisas do corpo podemos aproximar o tópico da aparência física, e às coisas do ânimo, o tópico do caráter do povo.

Considerando que a existência de um gênero etnográfico neste período é discutível, como já vimos, seria interessante levantar a possibilidade de as descrições de povos estrangeiros serem, nos mundos grego e romano, governadas por estes topoi epidíticos, ao invés de lugares-comuns etnográficos identificados pelos modernos. Considerando o treinamento e estudo retóricos pelos quais certamente Tácito passou - o 
Dialogus de oratoribus não parece ser obra de um leigo, decerto - é possível imaginar que ao menos ele possuía a compreensão de que lançava mão de tópica epidítica para construção dos seus germanos.

Portanto, podemos dizer que o êthos dos povos germânicos é retoricamente construído por Tácito a partir procedimentos relacionados ao gênero epidídico. Nas linhas a seguir, tentaremos delinear os traços fundamentais deste caráter germânico.

Lund $^{52}$ atribui quatro características gerais principais aos germanos na descrição de Tácito, que são: simplicitas, iracundia, inertia e libertas. Sua simplicidade pode ser constatada, por exemplo, no modo como comerciam, em suas técnicas de construção ou em suas vestimentas:

[...] interiores simplicius et antiquius permutatione mercium utuntur. $[\mathrm{V}, 4]$

[...] os [germanos] do interior empregam, de modo mais simples e antigo, a permutação de bens. [V, 4]

ne caementorum quidem apud illos aut tegularum usus: materia ad omnia utuntur informi et citra speciem aut delectationem. [XVI, 3]

Nem mesmo há o uso de cantarias ou tijolos entre eles: para tudo empregam madeira, informe e sem beleza ou deleite. [XVI, 3]

gerunt et ferarum pelles, proximi ripae neglegenter, ulteriores exquisitius, ut quibus nullus per commercia cultus. [XVII, 2]

Usam também peles de animais, os próximos à margem negligentemente, os do interior mais cuidadosamente, já que, para eles, por comércio nenhum adorno. [XVII, 2]

Sua ira faz-se ver no modo como matam seus escravos não por disciplina, mas por ímpeto:

\footnotetext{
${ }^{52}$ A. A. Lund (1999, pp. 62-72).
} 
verberare servum ac vinculis et opere coercere rarum: occidere solent, non disciplina et severitate, sed impetu et ira, ut inimicum, nisi quod impune est. [XXV, 2]

Vergastar servo e coagi-lo com grilhões e trabalho, raro: costumam matá-los, não por disciplina ou severidade, mas por ímpeto e ira, tal como inimigo, exceto que é impune. [XXV, 2]

Observamos sua indolência e predileção por ela:

[...] ipsi hebent, mira diversitate naturae, cum idem homines sic ament inertiam et oderint quietem. [XV, 1]

[...] eles mesmos vadiam, extraordinária sua inconstância de temperamento, visto que ao mesmo tempo os homens assim amam a indolência e odeiam a quietude. [XV, 1]

Por fim, vê-se a importância que tem a liberdade para eles em seu medo do cativeiro e na dificuldade militar que impuseram a Roma:

Memoriae proditur quasdam acies inclinatas iam et labantes a feminis restitutas constantia precum et obiectu pectorum et monstrata comminus captivitate, quam longe impatientius feminarum suarum nomine timent [...]. [VIII, 1]

Transmite-se que certas linhas já desbaratadas e vacilantes foram restituídas pelas mulheres através da constância das súplicas e interposição dos peitos, e mostrando próximo o cativeiro, o qual temem muito mais inquietamente em nome de suas mulheres [...]. [VIII, 1]

medio tam longi aevi spatio multa in vicem damna. non Samnis, non Poeni, non Hispaniae Galliaeve, ne Parthi quidem saepius admonuere: quippe regno Arsacis acrior est Germanorum libertas. [XXXVII, 3] 
Através de espaço tão longo de tempo, muitas as perdas de cada lado. Nem samnitas, nem fenícios, nem Hispânia ou Gália, nem mesmo partas admoestaram com mais frequiência: sem dúvida mais enérgica que o reino de Arsace é a liberdade dos germanos. [XXXVII, 3]

Evidentemente, estas características mencionadas por Lund são constituintes do êthos germânico, como pudemos ver; não obstante, acreditamos que seja possível observar este êthos ainda mais minuciosamente.

Os germanos são descritos por Tácito como um povo autóctone e homogêneo no aspecto:

Ipsos Germanos indigenas crediderim minimeque aliarum gentium adventibus et hospitiis mixtos [...]. [II, 1]

Os próprios germanos são autóctones, creio, e pouco misturados por imigrações de outras gentes e hospedagens [...]. [II, 1]

unde habitus quoque corporum, tamquam in tanto hominum numero, idem omnibus: truces et caerulei oculi, rutilae comae, magna corpora et tantum ad impetum valida. [IV, 2]

[...] daí também a aparência dos corpos, tão quanto em tamanho número de pessoas, a mesma em todos: olhos ferozes e azuis, cabeleira louro-avermelhada, corpos grandes e robustos somente ao ataque [...]. $[\mathrm{IV}, 2]$

Eles são ainda supersticiosos:

Auspicia sortesque ut qui maxime observant. [X, 1]

Observam, como os que mais o fazem, auspícios e sortes. [X, I]

Corajosos: 
Cum ventum in aciem, turpe principi virtute vinci, turpe comitatui virtutem principis non adaequare. iam vero infame in omnem vitam ac probrosum superstitem principi suo ex acie recessisse: illum defendere, tueri, sua quoque fortia facta gloriae eius adsignare praecipuum sacramentum est: principes pro victoria pugnant, comites pro principe. [XIV, 1]

Quando presente à linha, torpe ao líder ser superado em virtude, torpe ao companheiro não igualar sua virtude à do líder. Além disso, infâmia por toda vida e opróbrio ter se retirado da linha, sobrevivente ao seu líder; defendê-lo, protegê-lo, destinar seus valorosos feitos à glória dele é o principal juramento: líderes lutam pela vitória, companheiros lutam pelo líder. [XIV, 1]

\section{Belicosos:}

si civitas in qua orti sunt longa pace et otio torpeat, plerique nobilium adulescentium petunt ultro eas nationes, quae tum bellum aliquod gerunt, quia et ingrata genti quies et facilius inter ancipitia clarescunt magnumque comitatum non nisi vi belloque tueare [...]. [XIV, 2]

Caso a tribo em que cresceram entorpeça por longa paz e ócio, muitos dos jovens nobres buscam além aquelas nações que então empenham alguma guerra, porque repouso é ingrata à gente e se distinguem mais facilmente em meio a riscos, e não se mantém grande companhia senão por força e guerra. [XIV, 2]

Inconstantes em temperamento:

[...] ipsi hebent, mira diversitate naturae, cum idem homines sic ament inertiam et oderint quietem. [XV, 1]

[...] eles mesmos vadiam, extraordinária sua inconstância de temperamento, visto que ao mesmo tempo os homens assim amam a indolência e odeiam a quietude. [XV, 1] 
Morais e incorruptos em certos costumes:

Ergo saepta pudicitia agunt, nullis spectaculorum illecebris, nullis conviviorum irritationibus corruptae. litterarum secreta viri pariter ac feminae ignorant. [XIX, 1]

Vivem, pois, em cercada pudicícia, corrompidas por nenhum encantamento de espetáculos, nenhuma incitação de convívios. Os segredos dos bilhetes ignoram os homens e do mesmo modo as mulheres. [XIX, 1]

nemo enim illic vitia ridet, nec corrumpere et corrumpi saeculum vocatur. [XIX, 3]

Lá ninguém ri dos vícios, nem se denomina última moda corromper e ser corrompido. [XIX, 3]

Mas podem ser também pouco sábios e imprudentes:

gens non astuta nec callida aperit adhuc secreta pectoris licentia loci; ergo detecta et nuda omnium mens. [XX, 4]

Gente nem astuta nem prudente, lá desvela os segredos do peito, por licença da ocasião; o caráter de todos, pois, exposto e desnudo. [XXII, 4]

São, ainda, excessivos, como se vê em sua relação com jogo:

aleam, quod mirere, sobrii inter seria exercent, tanta lucrandi perdendive temeritate, ut, cum omnia defecerunt, extremo ac novissimo iactu de libertate ac de corpore contendant. 4. victus voluntariam servitutem adit; quamvis iuvenior, quamvis robustior, alligari se ac venire patitur. ea est in re prava pervicacia; ipsi fidem vocant. [XXIV, 3-4] 
Jogo de azar, é de se admirar, praticam sóbrios entre coisas sérias, com tamanha temeridade no ganhar ou perder que, quando desperdiçaram tudo, se medem às expensas de sua liberdade e de seu corpo em último e derradeiro lance. O perdedor segue para a servidão voluntária; embora mais jovem, embora mais robusto, deixa-se amarrar e vender. Esta é a obstinação na questão viciosa; os próprios chamam-na fidelidade. [XXIV, 3-4]

Uma característica enfatizada é seu senso de coletividade, por assim dizer: todos decidem em assembléia sobre qualquer assunto importante:

De minoribus rebus principes consultant, de maioribus omnes, ita tamen ut ea quoque, quorum penes plebem arbitrium est, apud principes praetractentur. [XI, 1]

Das matérias menores deliberam os chefes, das maiores, todos, embora de modo que também estas, cujo juízo dá-se entre a plebe, sejam prétratadas entre os comandantes. [XI, 1]

Partindo desta leitura, é possível afirmar que o êthos germânico geral, ou seja, aquele da primeira parte do texto de Tácito, é caracterizado pela simplicidade, ira, indolência, amor à liberdade, homogeneidade física, superstição, coragem, belicosidade, inconstância, moralidade, imprudência, excesso e senso de coletividade.

Ora, como sabemos, o gênero epidítico trata do elogio e da censura. Considerando esta caracterização dos povos germânicos, é possível afirmar que seu êthos possui tanto aspectos positivos quanto negativos, sendo ele portanto digno tanto de encômio quanto de vitupério. Dignos de elogio são sua simplicidade, coragem, castidade, seu amor pela liberdade, suas decisões coletivas; dignos de censura, sua indolência, ira, inconstância de temperamento, seus excessos na bebida e no jogo.

Este tom misto é resultado, supomos, de elementos extradiscursivos que também trabalham na construção deste êthos. Estes elementos extrediscursivos são as expectativas da recepção e as convenções que resultam disto, neste caso, e em especial, os estereótipos comumente associado a imagem do bárbaro do Norte. 
Dench $^{53}$ identifica os citas como os ancestrais da representação dos bárbaros setentrionais. Este povo era usualmente descrito, ao menos desde o século IV a. C., como simples, auto-suficiente, moral, frugal, nada ganancioso, casto e governado mais por bons hábitos que por leis ${ }^{54}$. Os celtas teriam sido os segundos nessa linha, sendo frequentemente caracterizados por sua temeridade, bravura irracional e impulsividade ${ }^{55}$. As similaridades entre estas caracterizações de citas e celtas, de um lado, e dos germanos de Tácito, de outro, nos parecem claras. Por isso, acreditamos que o estereótipo do bárbaro setentrional tem papel na descrição taciteana das populações germânicas.

Ademais, a relevância dada por Tácito a sua simplicidade, liberdade e senso de coletividade pode ser explicada por seu pensamento político, assim como pelo contexto político e moral de seu tempo. Sabe-se que, na Germania, há uma comparação implícita entre os costumes romanos e germânicos. Por exemplo, quando ele faz um relato sobre a castidade dos jovens germanos ou sobre a frugalidade de seus hábitos, há uma crítica subjacente à conduta impudente que predominava na $u r b s$ de então; quando ele nos fala sobre quão enérgica é sua liberdade ou sobre como eles deliberam coletivamente acerca de seus assuntos em assembléia, é impossível não se lembrar que Tácito, um admirador da velha República, vivia então em um principado que era propenso à tirania, e que a Germania foi escrita, possivelmente, apenas dois anos após a morte do imperador Domiciano.

Concluindo, podemos ver que o êthos das populações germânicas na primeira sessão da Germania de Tácito é constituído tanto por elementos intradiscursivos como extradiscursivos. Tácito constrói a imagem de seus germanos retoricamente, lançando mão de topoi próprios do gênero epidítico, os quais podem ser relacionados aos lugarescomuns etnográficos identificados pelos pesquisadores modernos. Ademais, é possível observar que a construção deste êthos é influenciada pelos estereótipos do bárbaro setentrional correntes no momento da produção do texto e pelo contexto moral e político do tempo em que Tácito vivia.

\footnotetext{
${ }_{53}^{53}$ E. Dench (2005, p. 49).

${ }^{54}$ J. B. Rives (1999, pp. 19-20).

${ }^{55} \operatorname{Idem}$ (p. 20).
} 


\subsection{A Germania como ekphraseis}

Dada a natureza mais abrangente de nosso trabalho, não estudaremos a ekphrasis em toda a sua profundidade ou de modo a esgotar o tema; em verdade, utilizaremos as considerações e conclusões daqueles que dela se ocuparam e as aplicaremos no estudo sobre a construção do êthos germânico em nosso texto-objeto.

Procurar uma definição precisa da ekphrasis impõe certa dificuldade. Em seu sentido mais difundido, aquele considerado pelos estudiosos da História da Arte, ekphrasis é apenas a descrição de um objeto, de uma obra artística. O sentido do termo é, porém, mais amplo. Podemos entende-lo como uma "descrição detalhada de uma pessoa ou objeto, cujo objetivo é a enargia” (H. Lausberg, §1333) ${ }^{56}$. Rodolpho desenvolve, dizendo que se trata de um

processo descritivo detalhado por meio do qual se pode produzir um "quadro" do objeto da descrição; temos então a enargia/evidência, que pode ser considerada figura de pensamento cuja finalidade é conferir vivacidade à imagem verbal..$^{57}$

Hansen $^{58}$ resume as definições para o termo ekphrasis em textos antigos: nos progymnasmata, exercícios de retórica escrito entre I e IV d. C. por retores gregos, assume o sentido de "exposição" ou "descrição", sendo associada a técnicas de amplificação de tópicas narrativas, composição de etopéias e exercícios de qualificação de causas deliberativas, judiciais e epidíticas.

Para um destes retores, Hélio Teão, que escreveu no século I d. C., a ekphrasis é um dircurso periegético, isto é, como já vimos, um discurso que narra em torno, pondo diante dos olhos com enargeia, "vividez", aquilo que deve ser mostrado ${ }^{59}$. Nas palavras do próprio:

\footnotetext{
${ }^{56}$ H. Lausberg (1966).

${ }^{57}$ M. Rodolpho (2013, p. 22).

${ }^{58}$ J. A. Hansen (2006, p. 85).

${ }^{59}$ Idem.
} 
A ékphrasis é um discurso descritivo [periêgêmatikos] que apresenta o objeto retratado vividamente [enargôs] diante dos olhos. Pode haver ékphrasis de pessoas, eventos, lugares e períodos de tempos. ${ }^{60}$

Definição parecida é encontrada nos Progymnasmata de Hermógenes de Tarso, escritos no século II. d. C.:

A écfrase é um enunciado que apresenta em detalhe, como dizem os teóricos, que tem a vividez e que põe sob os olhos o que mostra. ${ }^{61}$

Idênticas definições do termo são encontradas também nos exercícios de Aftônio de Antioquia e de Nicolau de Mira ${ }^{62}$.

Quanto à tipologia da ekphrasis, esta é variada. $\mathrm{Webb}^{63}$ afirma que o número de objetos da ekphrasis é ilimitado, e que aqueles citados nos manuais não o são por acaso, mas por fazerem parte de um sistema mais abrangente da retórica. Tendo em vista o elenco de objetos da ekphrasis feito por Webb a partir dos Progymnasmata ${ }^{64}$, sendo estes: eventos, pessoas, lugares, tempo, modos (tropoi), estado das coisas (koiroi), animais e plantas, festivais, pinturas e esculturas. Interessante notar quais são, nos Progymnasmata, as partes da narração: pessoa, eventos, lugar, maneira, causa. Assim, ela diz estes objetos recomendados pertencem a um sistema para analisar eventos e sua representação verbal, providenciando um ponto de contato com a narração, e que os elementos da narração podem ser explicados e narrados ecfrasticamente, ou seja, com grande vividez para apelar à imaginação da audiência ${ }^{65}$.

Tendo isto em mente, podemos justificar a análise da Germania como ekphrasis, em primeiro lugar, pela óbvia natureza periegética de ambas; também, pelo fato do texto taciteano tratar essencialmente de objetos nominalmente citados como próprios da

\footnotetext{
${ }^{60}$ Trecho traduzido por C. H. Dibbern (2013, p.35).

${ }^{61}$ Trecho traduzido por J. A. Hansen (2006, p. 103, nota 3).

${ }^{62}$ G. A. Kennedy (2003, pp. 117; 166).

${ }^{63}$ R. Webb (2009, p. 64).

${ }^{64}$ Idem.

${ }^{65}$ Idem (p. 65).
} 
ekhprasis, pessoas (os germanos) e lugares (a Germânia). Deste modo, ofereceremos a seguir uma análise da Germania como uma topografia e como uma etopeia.

\subsubsection{A Germania como topografia}

Lemos em Quint. Inst. 9.2.44:

Locorum quoque dilucida et significans descriptio eidem uirtuti

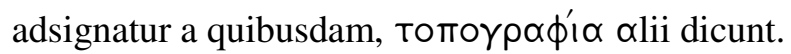

Também a descrição clara e vívida de lugares [locorum ... descriptio] é atribuída no mesmo valor por alguns, outros a chamam de topografia

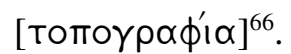

Topografia é a descrição ecfrástica de lugares reais ${ }^{67}$. A descrição territorial da Germânia, ou seja, a descriptio locorum ou topografia presente no texto, não é particularmente extensa e se encontra logo no início da obra. A primeira coisa que salta aos olhos nesta descrição, é o fato de que a Germânia parece ser descrita como um território a parte, separado. Lemos em I, 1:

Germania omnis a Gallis Raetisque et Pannoniis Rheno et Danuvio fluminibus, a Sarmatis Dacisque mutuo metu aut montibus separatur: cetera Oceanus ambit, latos sinus et insularum immensa spatia complectens, nuper cognitis quibusdam gentibus ac regibus, quos bellum aperuit.

A Germânia como um todo está separada dos gaulesess e dos retos e panônios pelos rios Reno e Danúbio, dos sármatas e dácios por mútuo medo ou montanhas; o Oceano circunda o restante, compreendendo vastas penínsulas e imensas extensões

\footnotetext{
66 Tradução nossa.
}

${ }^{67}$ J. A. Hansen (2006, p. 89). 
de ilhas, há pouco conhecidas através de algumas de suas gentes e reis, os quais a guerra desvelou.

A Germânia se encontra separada de seus vizinhos e do resto do mundo por barreiras naturais (oceano, rios, montanhas) ou por barreiras mentais (medo). Ao iniciar seu texto dizendo que "a Germânia está separada" [Germania [...] separatur] e elencar os obstáculos que a apartam dos outros todos, Tácito parece querer enfatizar que está região do mundo está de certo modo isolada. Tal possibilidade de leitura é reforçada em II, 1-2:

Ipsos Germanos indigenas crediderim minimeque aliarum gentium adventibus et hospitiis mixtos, quia nec terra olim sed classibus advehebantur qui mutare sedes quaerebant, et immensus ultra utque sic dixerim adversus Oceanus raris ab orbe nostro navibus aditur. 2. quis porro, praeter periculum horridi et ignoti maris, Asia aut Africa aut Italia relicta Germaniam peteret, informem terris, asperam caelo, tristem cultu aspectuque nisi si patria sit?

Os próprios germanos são autóctones, creio, e pouco misturados por imigrações de outras gentes e hospedagens, porque outrora não por terra, mas por frotas, viajavam os que desejavam mudar de regiões, e o imenso e di-lo-ia contrário oceano além é visitado, desde nosso mundo, por raros navios. 2. Além do mais, quem, afora o perigo do bravio e desconhecido mar, deixada Ásia, ou África ou Itália, dirigirse-ia à Germânia, informe na terra, severa no clima, triste no cultivo e aspecto, não fosse ela sua pátria?

Seu isolamento se dá pois os grandes deslocamentos populacionais ocorriam por mar, e não por terra, e o oceano que a circunda, perigoso por bravio e desconhecido, era raramente visitado pelos navios do Mediterrâneo. Desta forma, o oceano aparece como obstáculo quase intransponível para aqueles que desejam navegar até lá. Quantos aos outros limites naturais, seriam transponíveis? Provavelmente, mas decerto o esforço necessário não valeria à pena, dada a natureza da Germânia: informe na terra [informis 
terra], severa no clima [aspera caelo], triste no cultivo e aspecto [tristis cultu aspectuque].

Ora, este isolamento é o responsável pela singularidade do povo germânico: por conta dele, crê os germanos autóctones e pouco misturados com outras populações.

Tácito segue descrevendo a topografia. Em V, 1:

Terra etsi aliquanto specie differt, in universum tamen aut silvis horrida aut paludibus foeda, humidior qua Gallias, ventosior qua Noricum ac Pannoniam aspicit; satis ferax, frugiferarum arborum impatiens, pecorum fecunda, sed plerumque improcera.

Ainda que a terra difira um pouco na feição, no todo todavia bravia pelas florestas ou horrível pelos pântanos; se volta mais úmida às Gálias, mais ventosa à Nórica e Panônia; fértil em grãos, intolerante com árvores frutíferas, rica em greis, mas geralmente mal desenvolvidas.

Neste trecho, o retrato da Germânia não parece melhorar: a terra é bravia por causa da florestas [horrida siluis], horrível pelos pântanos [paludibus foeda], mais úmida de um lado [humida], mais cheia de vento do outro [uentosa]. É fértil em grãos [satis ferax] e rica em greis [pecorum fecunda], mas estes são pequenos [improcera]; ademais, é intolerante com as árvores frutíferas [frugiferarum arborum impatiens].

Não só é pobre na superfície, mas parece também que a Germânia é pobre em suas próprias entranhas. Lê-se em V, 3:

argentum et aurum propitiine an irati dii negaverint dubito. nec tamen adfirmaverim nullam Germaniae venam argentum aurumve gignere: quis enim scrutatus est?

Prata e ouro negaram-lhes os deuses - se por favor ou irados, não o sei. Todavia, não afirmaria que nenhuma veia da Germânia engendra prata ou ouro: quem, de fato, a explorou? 
E em VI, 1:

$\mathrm{Ne}$ ferrum quidem superest, sicut ex genere telorum colligitur.

Nem mesmo o ferro abunda, como se deduz do tipo das armas.

Além de mais um trecho que indica o isolamento da região ("todavia, não afirmaria que nenhuma veia da Germânia engendra prata ou ouro: quem, de fato, a explorou?"), ao que parece, é pobre tanto em metais preciosas como em metais menos nobres, como o ferro.

Pois bem: ao analisarmos os adjetivos utilizados por Tácito para descrever a Germânia - informis, aspera, tristis, horrida, foeda, humida, uentosa, impatiens -, a pintura que se faz é de um lugar hostil aos seus habitantes: sem forma, aspero, triste, bravio, horrível, úmido, ventoso, intolerante com o que cresce, com o plantio, com os animais. Um lugar que jamais alguém em sã consciência procuraria para viver.

Todavia, podemos dizer que essa característica, digamos, dura e ríspida de solo e clima da Germânia acaba por se tornar positiva. Como vimos em nosso estudo acerca do gênero etnográfico e da descrição dos povos, os elementos geográficos e climáticos eram sempre levados em conta para a explicação do caráter de um povo. Vimos também que alguns costumes germânicos parecem ser bem-vistos pelo autor Deste modo, observaremos a seguir, ao estudarmos a construção do êthos germânico, que a falta de conforto, luxo e exposições a todo o tipo de dificuldade territorial e climática acaba por moldar um tipo de homem duro e rústico, dotado de moralidade severa e restrita, o que, nos parece, é algo desejável para Tácito.

\subsubsection{A Germania como etopeia}

Mais uma vez, lemos em Quint. Inst. 9.2.58:

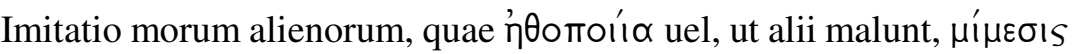
dicitur, iam inter leniores adfectus numerari potest; est enim posita fere in eludindo, sed uersatur et in factis et in dictis. 


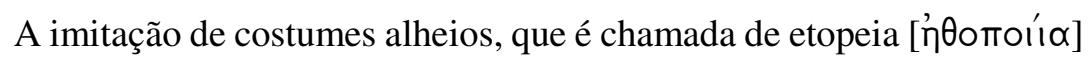
ou, como outros preferem, de mimese [ $\left.\mu^{\prime} \mu \varepsilon \sigma ı s\right]$, pode ser contada entre os afetos mais brandos, pois é usada, majoritariamente, na provocação, embora considere tanto os feitos como os ditos.

Etopeia é a descrição de paixões e caracteres ${ }^{68}$, que abrange as características físicas das personagens mas que se concentra nas em seus aspectos morais, e que serve bem ao gênero demonstrativo, pois convém ao elogio ou vitupério a enumeração das qualidades físicas e morais ${ }^{69}$. Ora, é razoável pensar a descrição dos germanos como uma etopeia: como já foi apontado anteriormente e como observaremos a seguir, abunda no texto a descrição dos costumes e dos aspectos físicos e morais dos germanos.

A análise feita anteriormente acerca do caráter dos germanos mostra que a construção do êthos germânico pode ser entendida como uma etopéia. A descrição de seus costumes assume claramente um viés moral e moralizante. Ademais, é interessante notar que mesmo a única descrição da aparência dos germanos encaminha para uma análise moralizante deste povo:

unde habitus quoque corporum, tamquam in tanto hominum numero, idem omnibus: truces et caerulei oculi, rutilae comae, magna corpora et tantum ad impetum valida. 3. laboris atque operum non eadem patientia, minimeque sitim aestumque tolerare, frigora atque inediam caelo solove adsueverunt. [IV, 2-3]

[...] daí também a aparência dos corpos, tão quanto em tamanho número de pessoas, a mesma em todos: olhos ferozes e azuis, cabeleira louro-avermelhada, corpos grandes e robustos somente para o ataque. Ao labor e exercício tolerância outra, e pouco habituaram-se a suportar sede e calor; frio e fome, sim, por clima ou solo. [IV, 2-3]

Temos que seus corpos são grandes e robustos, mas somente para o ataque, e não para o trabalho. Ora, tal descrição física introduz duas características anímicas fundamentais do germanos: o apreço à guerra e ao conflito e a indolência no que se refere

\footnotetext{
${ }^{68}$ J. A. Hansen (2006, p. 89).

${ }^{69}$ M. Rodolpho (2012, p. 184-5).
} 
ao trabalho. Se pensarmos, todavia, apenas na caracterização da parte física dos corpos, é possível afirmar que temos aqui uma breve prosopografia, que nada mais é que a descrição de pessoas ${ }^{70}$.

Já vimos que a caracterização destes bárbaros é feita de modo a mostrar as suas paixões, as suas qualidades anímicas, e que são descritos por sua simplicidade, ira, indolência, amor à liberdade, superstição, coragem, belicosidade, inconstância, moralidade, imprudência, excesso e senso de coletividade. Isto, acreditamos, seja o suficiente para apontarmos a descrição dos povos germânicos como uma etopeia.

\subsection{Conclusão}

Neste capítulo, estudamos a construção do êthos barbarorum na Germania de Tácito. Começamos dizendo que o êthos é construído de elementos discursivos que são extrínsecos e intrínsecos ao textos; os primeiros englobam a expectativa da recepção e seus estereótipos, enquanto que os outros se referem aos elementos próprios do discurso, como por exemplo preceitos da retórica. Passamos então para a análise da Germania como um retrato epidítico, apontando que os chamados topoi etnográficos utilizados na construção do êthos germânico podem ser compreendidos como lugares-comuns típicos do gênero demonstrativo da retórica, e que este êthos é, ademais, condicionado pelo estereótipo do bárbaro nórdico comum entre a recepção daquele momento.

Depois, tentamos mostrar que o texto de Tácito pode ser lido também como ekphraseis. Primeiramente, fizemos uma breve contextualização do termo, para então identificar dois tipos de descriptio/ekprasis presentes no texto: a topografia e a etopeia.

\footnotetext{
${ }^{70}$ J. A. Hansen (2006, p. 89).
} 


\section{Tradução da Germania de Tácito}

Segundo observações de diversos comentadores ${ }^{71}$, pode-se dizer que o texto da Germania é breve e conciso, agudo, ornado e uniforme, além de claro no geral, ainda que por vezes obscuro; que é composto por expressões elevadas e pouco usuais, por vocábulos e formas poéticas, por assimetrias, aliterações e anáforas, por ritmos variados; que seu vocabulário é preciso, embora não seja livre de inconstâncias.

Tais características apontadas pelos estudiosos são facilmente perceptíveis ao observarmos o texto de Tácito. Constatamos assimetria em passagens como quia nec terra olim sed classibus advehebantur qui mutare sedes quaerebant (II, 1); aliterações, como em a Sarmatis Dacisque mutuo metu aut montibus separatur (I, 1) ou em sed et proxima pars pectoris patet (XVII, 3); anáforas, como em mox rex vel princeps, prout aetas cuique, prout nobilitas, prout decus bellorum, prout facundia est [...] (XI, 5). Expressões poéticas também abudam, como lemos na passagem exigunt enim principis sui liberalitate illum bellatorem equum, illam cruentam victricemque frameam (XIV, 3), na qual a expressão ballatorem equum aparece primeiramente em Virgílio, sendo de uso comum apenas na poesia, e não na prosa ${ }^{72}$.

Dentre todas as características deste texto taciteano, a que mais salta aos olhos é sua extrema brevidade e concisão, decerto eco do estilo de seu modelo grego, Tucídides. É esta breuitas que deixa o texto obscuro por vezes. Um exemplo disto, muito comentado por aqueles que da Germania se ocuparam, é a passagem em que Tácito trata do uso da terra entre os germanos. Lê-se, em XXVI, 1:

agri pro numero cultorum ab universis in vices occupantur, quos mox inter se secundum dignationem partiuntur; facilitatem partiendi camporum spatia praestant.

Os campos são ocupados em turnos, de acordo com o número de cultivadores do todo, os quais são depois distribuídos entre eles segundo dignidade; as extensões dos campos garantem facilidade ao distribuir.

\footnotetext{
${ }^{71}$ Guiamo-nos a partir dos comentários estilísticos de: J. Perret (1949, p. 35); C.W. Mendell (1957, pp. 867); R. Syrme (1958, pp. 197, 340, 711-2); e J. B. Rives (1999, pp. 47, 60-1).

${ }^{72}$ J. G. C. Anderson (1997, p. 96).
} 
Quanto à precisão de seu vocabulário, afirma-se que Tácito é preciso ao evocar e nomear as instituições germânicas, se comparado, por exemplo a César em De Bello Gallico $^{73}$; no entanto, devemos sublinhar que essa maior precisão não elimina certas inconstâncias, como, por exemplo, no uso dos termos gens, populus e natio.

Postas estas características gerais do texto de Tácito, desejamos discorrer brevemente acerca dos nossos métodos de tradução.

Procuramos, durante todo o processo de versão do texto para o português, atentar as características estilísticas da Germania, para transpo-las, da melhor maneira possível, para o português. Ora, acima de tudo, tentamos manter a brevidade e concisão textual, marca que julgamos a mais fundamental desta obra, estilisticamente falando. Portanto, não adotamos um método, digamos assim, explicativo de tradução, a partir do qual pegamos uma passagem concisa e obscura do original e a desenvolvemos de modo mais explicativo e claro na tradução; não, naquelas passagens onde a obscuridade é unanimemente apontada, tentamos manter esta característica do original na tradução.

Atentamos também às figuras de linguagem, procurando mantê-las na tradução sempre que apareciam no original; a mesma atenção tivemos com a precisão do vocabulário, e não nos incomodamos em solucionar as inconstâncias do original: se inconstante lá, inconstante cá, pois o objetivo primeiro foi sempre manter a maior proximidade possível ao original latino.

Por fim, gostaríamos de anunciar o nosso débito à tradução portuguesa de Agostinho da Silva ${ }^{74}$, que nos forneceu doces sabores portugueses para os momentos em que o latim se tornava um tanto amargo.

A tradução foi feita a partir de texto latino retirado da edição de M. Hutton (1970).

${ }^{73}$ P. Grimal (1990, p. 142).

${ }^{74}$ A. da Silva (1972). 


\section{Cornelii Taciti}

\section{De origine et situ germanorum}

I. Germania omnis a Gallis Raetisque et Pannoniis Rheno et Danuvio fluminibus, a Sarmatis Dacisque mutuo metu aut montibus separatur: cetera Oceanus ambit, latos sinus et insularum immensa spatia complectens, nuper cognitis quibusdam gentibus ac regibus, quos bellum aperuit. 2. Rhenus, Raeticarum Alpium inaccesso ac praecipiti vertice ortus, modico flexu in occidentem versus septentrionali Oceano miscetur. 3. Danuvius molli et clementer edito montis Abnobae iugo effusus plures populos adit, donec in Ponticum mare sex meatibus erumpat; septimum os paludibus hauritur.

II. Ipsos Germanos indigenas crediderim minimeque aliarum gentium adventibus et hospitiis mixtos, quia nec terra olim sed classibus advehebantur qui mutare sedes quaerebant, et immensus ultra utque sic dixerim adversus Oceanus raris ab orbe nostro navibus aditur. 2. quis porro, praeter periculum horridi et ignoti maris, Asia aut Africa aut Italia relicta Germaniam peteret, informem terris, asperam caelo, tristem cultu aspectuque nisi si patria sit?

3. Celebrant carminibus antiquis, quod unum apud illos memoriae et annalium genus est, Tuistonem deum terra editum. ei filium Mannum originem gentis conditoresque Manno tres filios adsignant, e quorum nominibus proximi Oceano Ingaevones, medii Herminones, ceteri Istaevones vocentur. 4. quidam, ut in licentia vetustatis, plures deo ortos pluresque gentis appellationes, Marsos Gambrivios Suebos Vandilios adfirmant, eaque vera et antiqua nomina. 5. ceterum Germaniae vocabulum recens et nuper additum, quoniam qui primi Rhenum transgressi Gallos expulerint ac nunc Tungri, tunc Germani vocati sint: ita nationis nomen, non gentis, evaluisse paulatim, ut omnes primum a victore ob metum, mox et a se ipsis invento nomine Germani vocarentur. 


\section{Da origem e sítio dos germanos de Cornélio Tácito}

I. A Germânia como um todo ${ }^{1}$ está separada dos gauleses e dos récios e panônios pelos rios Reno e Danúbio, dos sármatas e dácios por mútuo medo ou montanhas²; o Oceano ${ }^{3}$ circunda o restante, compreendendo vastas penínsulas e imensas extensões de ilhas ${ }^{4}$, há pouco conhecidas através de algumas de suas gentes e reis, os quais a guerra desvelou. 2. O Reno, nascido do inacessível e precipitoso cume dos Alpes Réticos, após voltar-se ao ocidente com ligeira curva, se une ao Oceano setentrional ${ }^{5}$. O Danúbio, efuso do cimo do Monte Abnaba ${ }^{6}$, suave e levemente elevado, visita mais povos, até irromper no Mar Pôntico ${ }^{7}$ em seis de seus cursos; a sétima embocadura é engolida pelos pântanos.

II. Os próprios germanos são autóctones, creio, e pouco misturados por imigrações de outras gentes e hospedagens, porque outrora não por terra, mas por frotas, viajavam os que ansiavam mudar de regiões, e o imenso e, di-lo-ia, contrário oceano além é visitado, desde nosso mundo ${ }^{8}$, por raros navios. 2. Além do mais, quem, afora o perigo do bravio e desconhecido mar, deixada Ásia, ou África ou Itália, dirigir-se-ia à Germânia, disforme na terra, severa no clima, triste no cultivo e aspecto, não fosse ela sua pátria?

3. Celebram em canções antigas, que é o único gênero de registro e anais entre eles, o deus Tuistão, nascido da terra. A ele atribuem filho, Mano, origem da gente, e três filhos a Mano, seus fundadores, de cujos nomes chamam-se ingevões próximos ao Oceano, herminões ao centro, istevões os restantes. 4. Alguns afirmam, como que por permissão da antiguidade, ao deus mais descendentes e mais denominações de gente marsos, gambrívios, suevos, vandílios - e que tais são nomes verdadeiros e antigos; 5 . ademais, que o termo Germânia é recente e há pouco aplicado, porquanto aqueles primeiros que atravessaram o Reno e expulsaram os gauleses se chamavam germanos, agora tungros; assim, que paulatinamente prevaleceu nome de nação, não de gente, de

\footnotetext{
1 Tácito se refere à Germânia livre, excluindo as províncias Germania inferior e Germania superior. Germania omnis, "a Germânia como um todo", é uma reminiscência intencional ao Gallia omnis, que abre a obra De bello gallico, de Júlio César.

${ }^{2}$ As montanhas são aquelas que formam os Cárpatos.

${ }^{3}$ O Oceano em questão deve se referir, possivelmente, ao Mar do Norte e ao Mar Báltico

${ }^{4}$ As penínsulas e ilhas são identificadas como a Escandinávia, já que os antigos acreditavam que o extremo setentrional da Europa era formado por ilhas.

5 “Oceano setentrional" se refere ao Mar do Norte e ao Mar Báltico, que não eram distinguidos no período de Tácito.

${ }^{6}$ A Floresta Negra.

${ }^{7}$ O Mar Negro.

${ }^{8}$ Ou seja, desde o mundo sob a influência romana.
} 
modo que todos foram chamados pelo nome inventado, germano, primeiro pelo vencedor em razão do medo, depois por si mesmos. 
III. Fuisse et apud eos Herculem memorant, primumque omnium virorum fortium ituri in proelia canunt. sunt illis haec quoque carmina quorum relatu, quem baritum vocant, accendunt animos futuraeque pugnae fortunam ipso cantu augurantur; terrent enim trepidantve, prout sonuit acies, nec tam vocis ille quam virtutis concentus videtur. 2. adfectatur praecipue asperitas soni et fractum murmur, obiectis ad os scutis, quo plenior et gravior vox repercussu intumescat. 3. ceterum et Ulixen quidam opinantur longo illo et fabuloso errore in hunc Oceanum delatum adisse Germaniae terras, Asciburgiumque, quod in ripa Rheni situm hodieque incolitur, ab illo constitutum nominatumque; aram quin etiam Ulixi consecratam, adiecto Laertae patris nomine, eodem loco olim repertam, monumentaque et tumulos quosdam Graecis litteris inscriptos in confinio Germaniae Raetiaeque adhuc extare. 4. quae neque confirmare argumentis neque refellere in animo est: ex ingenio suo quisque demat vel addat fidem.

IV. Ipse eorum opinionibus accedo qui Germaniae populos nullis [aliis] aliarum nationum conubiis infectos propriam et sinceram et tantum sui similem gentem extitisse arbitrantur. 2. unde habitus quoque corporum, tamquam in tanto hominum numero, idem omnibus: truces et caerulei oculi, rutilae comae, magna corpora et tantum ad impetum valida. 3 . laboris atque operum non eadem patientia, minimeque sitim aestumque tolerare, frigora atque inediam caelo solove adsueverunt. 
III. Recordam que também Hércules esteve entre eles, e cantam o primeiro dentre todos os varões destemidos quando prestes a pelejar. Eles possuem, outrossim, aquelas canções, por cuja entoação, a qual denominam barito, a coragem inflamam e auguram a fortuna da batalha futura pelo próprio canto; de fato, aterrorizam ou estremecem conforme soou a linha, e este não é considerado tanto uma harmonia de vozes quanto de valores. 2. Procura-se, em particular, aspereza do som e quebrado murmúrio, postos à boca os escudos, para que mais plena e grave a voz intumesça pelo reverberar. 3. Ademais, alguns opinam que também Ulisses, levado a este Oceano durante aquela sua longa e celebrada errância, as terras da Germânia visitou, e que Ascibúrgio ${ }^{9}$, que se situa à margem do Reno e hoje é habitada, foi fundada e nomeada por ele; em realidade, altar consagrado por Ulisses, o nome de seu pai Laertes incluído, foi outrora encontrado no mesmo local, e monumentos e alguns túmulos inscritos com letras gregas ainda existem na fronteira da Germânia e da Récia ${ }^{10}$. 4. Isto não intento confirmar com argumentos nem refutar no pensamento: que, consoante seu engenho, cada um subtraia ou adicione crença ${ }^{11}$.

IV. Eu mesmo concordo com as opiniões daqueles que julgam que os povos da Germânia aparentam não ter sido maculados por quaisquer outras uniões com outras nações, gente peculiar e pura e símile apenas a si mesma; 2. daí também a aparência dos corpos, tão quanto em tamanho número de pessoas, a mesma em todos: olhos ferozes e azuis, cabeleira louro-avermelhada, corpos grandes e robustos somente para o ataque; 3. ao labor e exercício tolerância outra ${ }^{12}$, e pouco se habituaram a suportar sede e calor; frio e fome, sim, por clima ou solo.

\footnotetext{
9 À margem oeste do rio Reno, é identificada como a atual Asberg, distrito de Moers, Renánia do NorteVestfália, Alemanha.

${ }^{10}$ A arqueologia não encontrou elementos que possam confirmar a presença grega na região. Vale notar que o próprio Tácito parece duvidar do relato, como é possível observar na oração seguinte.

${ }^{11}$ Fórmula típica encontrada em historiadores gregos. Ver Her. 2. 46; Tuc. 6. 2. 1; Dion. Halic. 1. 48. 4; Luc. Hist. conscri. 60.

${ }^{12}$ Lançamos mão de "outra" para traduzir o lat. non eadem [est], "não é a mesma", para manter a brevidade e concisão da passagem.
} 
V. Terra etsi aliquanto specie differt, in universum tamen aut silvis horrida aut paludibus foeda, humidior qua Gallias, ventosior qua Noricum ac Pannoniam aspicit; satis ferax, frugiferarum arborum impatiens, pecorum fecunda, sed plerumque improcera. 2. ne armentis quidem suus honor aut gloria frontis: numero gaudent, eaeque solae et gratissimae opes sunt. 3. argentum et aurum propitiine an irati dii negaverint dubito. nec tamen adfirmaverim nullam Germaniae venam argentum aurumve gignere: quis enim scrutatus est? 4. possessione et usu haud perinde adficiuntur: est videre apud illos argentea vasa, legatis et principibus eorum muneri data, non in alia vilitate quam quae humo finguntur. quamquam proximi ob usum commerciorum aurum et argentum in pretio habent formasque quasdam nostrae pecuniae agnoscunt atque eligunt: interiores simplicius et antiquius permutatione mercium utuntur. 5. pecuniam probant veterem et diu notam, serratos bigatosque. argentum quoque magis quam aurum sequuntur, nulla adfectione animi, sed quia numerus argenteorum facilior usui est promisca ac vilia mercantibus.

VI. Ne ferrum quidem superest, sicut ex genere telorum colligitur. rari gladiis aut maioribus lanceis utuntur: hastas vel ipsorum vocabulo frameas gerunt angusto et brevi ferro, sed ita acri et ad usum habili, ut eodem telo, prout ratio poscit, vel comminus vel eminus pugnent. 2. et eques quidem scuto frameaque contentus est, pedites et missilia spargunt, pluraque singuli, atque in immensum vibrant, nudi aut sagulo leves. nulla cultus iactatio: scuta tantum lectissimis coloribus distinguunt. 3. paucis loricae, vix uni alterive cassis aut galea. equi non forma, non velocitate conspicui. sed nec variare gyros in morem nostrum docentur: in rectum aut uno flexu dextros agunt, ita coniuncto orbe ut nemo posterior sit. 4. in universum aestimanti plus penes peditem roboris; eoque mixti proeliantur, apta et congruente ad equestrem pugnam velocitate peditum, quos ex omni iuventute delectos ante aciem locant. 5. definitur et numerus: centeni ex singulis pagis sunt, idque ipsum inter suos vocantur, et quod primo numerus fuit, iam nomen et honor est. 6. acies per cuneos componitur. cedere loco, dummodo rursus instes, consilii quam formidinis arbitrantur. corpora suorum etiam in dubiis proeliis referunt. scutum reliquisse praecipuum flagitium, nec aut sacris adesse aut concilium inire ignominioso fas, multique superstites bellorum infamiam laqueo finierunt. 
V. Ainda que a terra difira um pouco na feição, no todo todavia bravia pelas florestas ou horrível pelos pântanos, se volta mais úmida às Gálias, mais ventosa à Nórica ${ }^{13} \mathrm{e}$ Panônia ${ }^{14}$; fértil em grãos, intolerante com árvores frutíferas, fecunda em greis, mas geralmente mal desenvolvidos. 2. Nem mesmo aos gados sua honra ou glória de fronte; regozijam-se com seu número, e eles são suas únicas e mais caras riquezas. 3. Prata e ouro negaram-lhes os deuses - se por favor ou irados, não o sei. Todavia, não afirmaria que nenhuma veia da Germânia engendra prata ou ouro: quem, de fato, a explorou? 4. Não são afetados por sua posse e uso igualmente. São vistos entre eles aparatos de prata, dados como presente a seus embaixadores e comandantes, a não outro baixo preço que o quê se molda do chão. Entretanto, os próximos têm em valor ouro e prata pela prática do comércio, e reconhecem e selecionam determinadas formas da nossa moeda; os do interior empregam, de modo mais simples e antigo, a permutação de bens. 5. Apreciam velha moeda e há muito conhecida, as de talho e bigas ${ }^{15}$; preferem, outrossim, prata mais que ouro, não por alguma disposição de ânimo, mas porque o número das de prata é de uso mais fácil aos que comerciam o comum e barato.

VI. Nem mesmo o ferro abunda, como se deduz do tipo das armas. Raros empregam gládios ou lanças longas; carregam hastas ou, no termo deles, frâmeas ${ }^{16}$, de ponta estreita e curta, mas tão aguda e adequada ao uso que combatem, no corpo a corpo ou à distância, conforme demanda o caso, com a mesma arma. 2. Em verdade, também cavaleiro se contenta com escudo e frâmea, os infantes espargem também dardos, um só, muitos, e os vibram ao longe, nus ou leves com sago ${ }^{17}$. Jactância pelo adorno, nenhuma: os escudos tanto se distinguem pelas seletíssimas cores. 3. A poucos loricas ${ }^{18}$, apenas a um ou outro elmo de metal ou couro. Os cavalos não são reconhecidos por beleza nem velocidade, mas também não são ensinados, ao nosso modo, a variar giros: conduzem-nos em reta ou com volta à direita, o círculo unido de modo tal que ninguém seja último. 4. Considerando o todo, mais força na infantaria, e por isso pelejam misturados, adequada e adaptada ao combate equestre a velocidade dos infantes, os quais, escolhidos dentre toda juventude, alocam ante a linha. 5. É definido também o número: há centos de cada marca, e assim

\footnotetext{
${ }^{13}$ Atualmente Áustria e parte da Eslovênia.

${ }^{14}$ Região que compreendia a parte setentrional da península balcânica e a porção oriental dos atuais Estados da Áustria e da Hungria.

${ }^{15}$ Isto é, os denarii cunhados durante a República, até 55 a. C.

${ }^{16}$ Lança curta, cuja ponta era forjada em ferro.

${ }^{17}$ Espécie de casaco militar curto.

${ }^{18}$ Lorica, aqui, como sinônimo de armadura de metal ou couro.
} 
mesmo chamam-se entre os seus, e o que primeiro foi número, agora é nome e honra. 6. A linha é organizada em cunhas ${ }^{19}$. Ceder posição, enquanto se os pressiona para trás, julgam mais estratégia que temor. Recolhem os corpos dos seus também durante as batalhas incertas. Ter abandonado o escudo, particular desonra, e não é permitido ao ignominioso participar dos rituais ou ir à assembleia; muitos sobreviventes de guerras findaram no laço a infâmia.

${ }^{19}$ Por esta formação lembrar a cabeça de um javali, foi posteriormente conhecida entre os romanos como caput porcinum. 
VII. Reges ex nobilitate, duces ex virtute sumunt. nec regibus infinita ac libera potestas, et duces exemplo potius quam imperio, si prompti, si conspicui, si ante aciem agant, admiratione praesunt. 2. ceterum neque animadvertere neque vincire, ne verberare quidem nisi sacerdotibus permissum, non quasi in poenam nec ducis iussu, sed velut deo imperante, quem adesse bellantibus credunt. 3. effigiesque et signa quaedam detracta lucis in proelium ferunt; quodque praecipuum fortitudinis incitamentum est, non casus nec fortuita conglobatio turmam aut cuneum facit, sed familiae et propinquitates; et in proximo pignora, unde feminarum ululatus audiri, unde vagitus infantium. 4 . hi cuique sanctissimi testes, hi maximi laudatores: ad matres, ad coniuges vulnera ferunt; nec illae numerare et exigere plagas pavent, cibosque et hortamina pugnantibus gestant.

VIII. Memoriae proditur quasdam acies inclinatas iam et labantes a feminis restitutas constantia precum et obiectu pectorum et monstrata comminus captivitate, quam longe impatientius feminarum suarum nomine timent, adeo ut efficacius obligentur animi civitatum quibus inter obsides puellae quoque nobiles imperantur. 2. inesse quin etiam sanctum aliquid et providum putant, nec aut consilia earum aspernantur aut responsa neglegunt. 3. vidimus sub divo Vespasiano Veledam diu apud plerosque numinis loco habitam; sed et olim Auriniam et complures alias venerati sunt, non adulatione nec tamquam facerent deas. 
VII. Tomam reis consoante nobreza, generais ${ }^{20}$ consoante virtude; nem mesmo aos reis poder ilimitado e irrestrito, e os generais comandam por exemplo mais que por império, por admiração se dispostos, se visíveis, se lideram ante a linha. 2. Ademais, escarmentar e atar, ou mesmo vergastar, é permitido somente aos sacerdotes, não como pena ou por ordem do general, mas como que pelo deus que impera, o qual creem assistir os que guerreiam. 3. Levam à peleja certas efígies e signos retirados dos bosques sagrados, e o que é o principal estímulo a coragem: nem acaso nem fortuita aglomeração cria tropa ou cunha, mas familiares e parentescos; os entes queridos na proximidade, donde são ouvidos os ululos das mulheres, donde o choro das crianças. 4. Estes, a todos as mais sagradas testemunhas, estes, os maiores elogiadores; levam as feridas às mães, às esposas, e elas não temem enumerar e examinar os ferimentos, e trazem alimentos e incitamentos aos combatentes.

VIII. É transmitido que certas linhas já desbaratadas e vacilantes foram restituídas pelas mulheres através da constância das súplicas e interposição dos peitos, e mostrando próximo o cativeiro, o qual temem muito mais inquietamente em nome de suas mulheres, a tal ponto que é mais eficazmente empenhada a disposição dos povos dos quais demandam, dentre os reféns, também donzelas nobres. 2. Mais, avaliam que há nelas também algo sagrado e previdente, e não desdenham os conselhos delas ou negligenciam suas respostas. 3. Vimos, sob o divino Vespasiano ${ }^{21}$, Veleda $^{22}$ tida por muito, entre muitos, na condição de nume; mas também outrora Aurínia ${ }^{23}$ e outras várias foram veneradas, não por adulação, nem para que se criasse deusas.

\footnotetext{
20 "General", no sentido de "líder militar", será a palavra sempre empregada para a tradução do lat. $d u x$.

${ }^{21}$ Ou seja, durante o governo de dez anos (69 d. C. - 79 d. C.) do imperador Vespasiano.

${ }^{22}$ Profetisa dos bructeros, foi figura proeminente durante a rebelião dos batavos, ocorrida entre 69 d. C. e 70 d. C. e encabeçada pelo líder batavo romanizado Caio Júlio Civil.

${ }^{23}$ Não se sabe quem foi Aurínia.
} 
IX. Deorum maxime Mercurium colunt, cui certis diebus humanis quoque hostiis litare fas habent. Herculem ac Martem concessis animalibus placant. 2. pars Sueborum et Isidi sacrificat: unde causa et origo peregrino sacro parum comperi nisi quod signum ipsum in modum liburnae figuratum docet advectam religionem. 3. ceterum nec cohibere parietibus deos neque in ullam humani oris speciem adsimulare ex magnitudine caelestium arbitrantur: lucos ac nemora consecrant deorumque nominibus appellant secretum illud, quod sola reverentia vident.

X. Auspicia sortesque ut qui maxime observant. sortium consuetudo simplex. virgam frugiferae arbori decisam in surculos amputant eosque notis quibusdam discretos super candidam vestem temere ac fortuito spargunt. 2. mox, si publice consultetur, sacerdos civitatis, sin privatim, ipse pater familiae, precatus deos caelumque suspiciens ter singulos tollit, sublatos secundum impressam ante notam interpretatur. 3. si prohibuerunt, nulla de eadem re in eundem diem consultatio; sin permissum, auspiciorum adhuc fides exigitur. et illud quidem etiam hic notum, avium voces volatusque interrogare: proprium gentis equorum quoque praesagia ac monitus experiri. 4. publice aluntur isdem nemoribus ac lucis, candidi et nullo mortali opere contacti; quos pressos sacro curru sacerdos ac rex vel princeps civitatis comitantur hinnitusque ac fremitus observant. 5. nec ulli auspicio maior fides, non solum apud plebem, sed apud proceres, apud sacerdotes; se enim ministros deorum, illos conscios putant. est et alia observatio auspiciorum, qua gravium bellorum eventus explorant. 6. eius gentis cum qua bellum est captivum quoquo modo interceptum cum electo popularium suorum, patriis quemque armis, committunt: victoria huius vel illius pro praeiudicio accipitur. 
IX. Dentre os deuses, cultuam sobretudo Mercúrio ${ }^{24}$, ao qual, em determinados dias, têm por justo sacrificar também vítimas humanas. Aplacam Hércules ${ }^{25}$ e Marte $^{26}$ com animais permitidos. 2. Parte dos suevos sacrifica também a Isis ${ }^{27}$; pouco sei da causa e origem do culto estrangeiro, senão que seu próprio signo, figurado ao modo de liburna ${ }^{28}$, denota religião importada. 3. Ademais, não julgam confinar os deuses entre paredes ou assemelhá-los a qualquer forma da feição humana consoante à grandeza dos celestiais; consagram bosques e florestas e, por nomes de deuses, chamam aquele mistério que veem somente por reverência.

X. Observam, como os que mais o fazem, auspícios e sortes. A prática das sortes é simples. Ramo de árvore frutífera podado, cortam-no em pedaços, e, distinguidos por certos sinais, espargem-nos, fortuitamente e ao acaso, sobre veste branca; 2. depois, se consultam em favor do público, o sacerdote do povo, se do privado, o próprio pai de família, aos deuses suplicante e olhando para o céu, pega três vezes um só e interpreta os pegados segundo o sinal antes marcado. 3. Se proibitivos, sobre a mesma matéria, no mesmo dia, mais consulta nenhuma; se permissivo, é exigida ainda garantia dos auspícios. Em verdade, também aqui sabe-se interpretar as vozes e voos das aves; é próprio dessa gente recorrer também aos presságios e predições de cavalos. 4. Às expensas públicas são alimentados nas mesmas florestas e bosques, brancos e por nenhum trabalho mundano aviltados, os quais, presos a carro sagrado, sacerdote e rei ou líder ${ }^{29}$ do povo seguem, e observam seus relinchos e resfôlegos. 5. E a nenhum auspício fé maior, não só entre a plebe, mas entre os próceres, entre os sacerdotes, pois julgam-se servidores dos deuses, aqueles, seus confidentes. Há também outra observação de auspícios, a partir da qual perscrutam os destinos das graves guerras: 6. confrontam prisioneiro daquela gente com a qual guerreiam, de algum modo interceptado, com o escolhido de sua população, com as armas pátrias cada qual; aceita-se vitória deste ou daquele por juízo.

\footnotetext{
${ }^{24}$ Gregos e romanos costumavam interpretar divindades, conceitos e práticas religiosas estrangeiras utilizando conceitos de sua própria cultura. Neste caso, sabemos que Mercúrio se refere ao deus protogerm. *Wodānaz, posteriormente conhecido como Wotan e Odin, como podemos aferir através da interpretativo germanica dos nomes de semana romanos: ing. wednesday, nor. onsdag, do lat. mercuri dies. 25 Proto-germ. *Dunraz, posteriormente conhecido como Donar e Thor. Às vezes, também identificado como Júpiter.

${ }^{26}$ Proto-germ. *Tiwaz, depois conhecido pelo nome escandinavo Týr.

${ }^{27}$ Neste caso, ao indicar a origem estrangeira do culto, Tácito parece não estar fazendo uma interpretatio romana, mas indicando que havia, entre os suevos, o culto à Isis.

${ }^{28}$ Navio de guerra ligeiro birreme, com uma vela central, utilizado pelos liburnianos, possivelmente uma tribo ilíria.

${ }^{29} \mathrm{O}$ lat. princeps é de difícil tradução no contexto. Optamos pelo termo líder, que nos pareceu o mais adequado.
} 
XI. De minoribus rebus principes consultant, de maioribus omnes, ita tamen ut ea quoque, quorum penes plebem arbitrium est, apud principes praetractentur. 2. coeunt, nisi quid fortuitum et subitum incidit, certis diebus, cum aut incohatur luna aut impletur; nam agendis rebus hoc auspicatissimum initium credunt. nec dierum numerum, ut nos, sed noctium computant. sic constituunt, sic condicunt: nox ducere diem videtur. 3. illud ex libertate vitium, quod non simul nec ut iussi conveniunt, sed et alter et tertius dies cunctatione coeuntium absumitur. 4. ut turbae placuit, considunt armati. silentium per sacerdotes, quibus tum et coercendi ius est, imperatur. 5. mox rex vel princeps, prout aetas cuique, prout nobilitas, prout decus bellorum, prout facundia est, audiuntur auctoritate suadendi magis quam iubendi potestate. 6 . si displicuit sententia, fremitu aspernantur; sin placuit, frameas concutiunt: honoratissimum adsensus genus est armis laudare.

XII. Licet apud concilium accusare quoque et discrimen capitis intendere. distinctio poenarum ex delicto: proditores et transfugas arboribus suspendunt, ignavos et imbelles et corpore infames caeno ac palude, iniecta insuper crate, mergunt. 2. diversitas supplicii illuc respicit, tamquam scelera ostendi oporteat dum puniuntur, flagitia abscondi. sed et levioribus delictis pro modo poena: equorum pecorumque numero convicti multantur. pars multae regi vel civitati, pars ipsi qui vindicatur vel propinquis eius exsolvitur. 3. eliguntur in isdem conciliis et principes qui iura per pagos vicosque reddunt; centeni singulis ex plebe comites consilium simul et auctoritas adsunt. 
XI. Das matérias menores deliberam os líderes ${ }^{30}$, das maiores, todos, embora de modo que também estas, cujo juízo dá-se entre a plebe ${ }^{31}$, sejam tratadas antes entre os líderes. 2. Reúnem-se, se nada de fortuito ou imprevisto incidiu, em dias determinados, quando nova a lua ou cheia, pois creem este início o mais auspicioso para tratar das matérias. Não contam o número de dias como nós, mas o de noites. Assim determinam, assim acordam: a noite parece conduzir o dia. 3. Da liberdade este vício, pois não se reúnem ao mesmo tempo nem como ordenados, mas são consumidos dois ou três dias pela demora dos participantes. 4. Quando agradou à multidão, armados tomam assento. Silêncio é demandado pelos sacerdotes, que então têm direito de coagir. 5. Depois, rei ou líder, conforme idade de cada, conforme nobreza, conforme decoro nas guerras, conforme haja eloquência, são ouvidos, por autoridade de persuadir mais que poder de ordenar. 6. Se desagradou a sentença, rejeitam com bramido; se agradou, agitam as frâmeas: aplaudir com as armas é o mais honrado gênero de aprovação.

XII. Lícito, ante a assembleia, também acusar e pretender pena capital. Diferença entre penas, consoante delito: suspendem das árvores traidores e desertores, mergulham ignavos e imbeles e infames de corpo em lodaçal e pântano ${ }^{32}$, grade posta por cima. 2. A diversidade de castigo respeita isso, que convém que sejam demonstrados crimes enquanto punidos, que sejam ocultadas desonras. Mas também a delitos mais leves pena proporcional: culpados são multados em número de cavalos e greis; parte da multa é paga ao rei ou ao povo, parte àquele mesmo que vindica ou aos parentes dele. 3. São eleitos, nas mesmas assembleias, líderes ${ }^{33}$ que outorgam justiça por comarcas e vilas; a cada um, cem associados da plebe assistem ao mesmo tempo com conselho e autoridade.

\footnotetext{
30 "Líderes", lat. principes, pode ser aqui tomado em sentido mais amplo, para incluir todos os nobiles do povo.

31 "Plebe", lat. plebs, como a massa de homens livres da tribo.

$32 \mathrm{O}$ costume de se mergulhar pessoas no pântano pode ser atestado pelo grande número de corpos mumificados, os chamados bog bodies, encontrados em regiões pantanosas da Alemanha, Dinamarca, Holanda e Suécia.

${ }^{33} \mathrm{Ou}$ seja, estes próceres exerciam função próxima ao do pretor e outros magistrados romanos.
} 
XIII. Nihil autem neque publicae neque privatae rei nisi armati agunt. sed arma sumere non ante cuiquam moris quam civitas suffecturum probaverit. tum in ipso concilio vel principum aliquis vel pater vel propinqui scuto frameaque iuvenem ornant: haec apud illos toga, hic primus iuventae honos; ante hoc domus pars videntur, mox rei publicae. 2. insignis nobilitas aut magna patrum merita principis dignationem etiam adulescentulis adsignant: †ceteris robustioribus ac iam pridem probatis adgregantur, nec rubor inter comites aspici. 3. gradus quin etiam ipse comitatus habet, iudicio eius quem sectantur; magnaque et comitum aemulatio, quibus primus apud principem suum locus, et principum, cui plurimi et acerrimi comites. 4. haec dignitas, hae vires: magno semper electorum iuvenum globo circumdari in pace decus, in bello praesidium. nec solum in sua gente cuique, sed apud finitimas quoque civitates id nomen, ea gloria est, si numero ac virtute comitatus emineat; expetuntur enim legationibus et muneribus ornantur et ipsa plerumque fama bella profligant.

XIV. Cum ventum in aciem, turpe principi virtute vinci, turpe comitatui virtutem principis non adaequare. iam vero infame in omnem vitam ac probrosum superstitem principi suo ex acie recessisse: illum defendere, tueri, sua quoque fortia facta gloriae eius adsignare praecipuum sacramentum est: principes pro victoria pugnant, comites pro principe. 2. si civitas in qua orti sunt longa pace et otio torpeat, plerique nobilium adulescentium petunt ultro eas nationes, quae tum bellum aliquod gerunt, quia et ingrata genti quies et facilius inter ancipitia clarescunt magnumque comitatum non nisi vi belloque tueare; 3. exigunt enim principis sui liberalitate illum bellatorem equum, illam cruentam victricemque frameam; nam epulae et quamquam incompti, largi tamen apparatus pro stipendio cedunt. materia munificentiae per bella et raptus. 4. nec arare terram aut expectare annum tam facile persuaseris quam vocare hostem et vulnera mereri; pigrum quin immo et iners videtur sudore adquirere quod possis sanguine parare. 
XIII. Ora, não tratam nem da matéria pública nem da privada senão armados. Mas é costume ninguém empunhar armas antes que o povo tenha aprovado que será capaz. Então, na própria assembleia, um dos líderes ou pai ou parentes equipam o jovem com escudo e frâmea: esta, entre eles, a toga ${ }^{34}$, esta a primeira honra da juventude; antes disso, ele é considerado parte da casa, depois, do que é público. 2. Nobreza insigne ou grandiosas ações dos antepassados conferem estima do chefe também aos adolescentes; são agregados aos demais, mais robustos e já há tempos provados, e não é visto rubor entre os companheiros. 3. Ademais, a própria companhia ${ }^{35}$ tem graduações, a partir do discernimento daquele a quem seguem; grande também a rivalidade entre companheiros - quem tem o primeiro lugar junto ao seu líder - e entre líderes - qual tem companheiros mais numerosos e agudos. 4. Esta a dignidade, esta a força: sempre rodear-se de grande círculo de jovens escolhidos, decoro na paz, assistência na guerra. E não só junto a sua gente mas também entre os povos vizinhos há renome, glória, caso sua companhia sobressaia por número e valor; de fato, são procurados pelos embaixadores e com presentes prezados, e geralmente dão cabo das guerras com a própria fama.

XIV. Quando presente à linha, torpe ao líder ser superado em virtude, torpe ao companheiro não igualar sua virtude à do líder. Além disso, infâmia por toda vida e opróbrio ter se retirado da linha, sobrevivente ao seu líder; defendê-lo, protegê-lo, destinar seus valorosos feitos à glória dele é principal juramento: líderes lutam pela vitória, companheiros lutam pelo líder. 2. Caso o povo em que cresceram entorpeça por longa paz e ócio, muitos dos jovens nobres buscam além aquelas nações que então empenham alguma guerra, porque repouso é ingrato à gente e se distinguem mais facilmente em meio a riscos, e não grande companhia é mantida senão por força e guerra. 3. De fato, exigem da liberalidade de seu líder aquele fero corcel, aquela cruel e vitoriosa frâmea; com efeito, banquetes e sua preparação, embora rude, generosa, equivalem ao pagamento. O recurso da munificência, das guerras e saques. 4. Nem a arar terra nem a expectar colheita anual se persuadi-los-ia tão facilmente quanto a provocar inimigo e ganhar feridas; parece-lhes, sim, indolência e preguiça adquirir com suor o que se pode obter com sangue.

\footnotetext{
${ }^{34}$ Isto é, o porte das armas entre os germanos equivale ao uso toga uirillis, branca e lisa, envergada pelos romanos assim que era atingida a idade adulta, por volta dos 16 anos.

${ }^{35} \mathrm{O}$ comitatus, aqui traduzido por "companhia", era estrutura fundamental da sociedade germânica. Alguns veem nele as origens do que veio a ser identificado como o feudalismo medieval.
} 
XV. Quotiens bella non ineunt, non multum venatibus, plus per otium transigunt, dediti somno ciboque: fortissimus quisque ac bellicosissimus nihil agens, delegata domus et penatium et agrorum cura feminis senibusque et infirmissimo cuique ex familia, ipsi hebent, mira diversitate naturae, cum idem homines sic ament inertiam et oderint quietem. 2. mos est civitatibus ultro ac viritim conferre principibus vel armentorum vel frugum, quod pro honore acceptum etiam necessitatibus subvenit. 3. gaudent praecipue finitimarum gentium donis, quae non modo a singulis, sed et publice mittuntur, electi equi, magn<ific $>$ a arma, phalerae torquesque; iam et pecuniam accipere docuimus.

XVI. Nullas Germanorum populis urbes habitari satis notum est, ne pati quidem inter se iunctas sedes. colunt discreti ac diversi, ut fons, ut campus, ut nemus placuit. 2. vicos locant non in nostrum morem conexis et cohaerentibus aedificiis: suam quisque domum spatio circumdat, sive adversus casus ignis remedium sive inscitia aedificandi. 3. ne caementorum quidem apud illos aut tegularum usus: materia ad omnia utuntur informi et citra speciem aut delectationem. quaedam loca diligentius inlinunt terra ita pura ac splendente ut picturam ac lineamenta colorum imitetur. 4. solent et subterraneos specus aperire eosque multo insuper fimo onerant, suffugium hiemis et receptaculum frugibus, quia rigorem frigorum eius modi loci molliunt, et si quando hostis advenit, aperta populatur, abdita autem et defossa aut ignorantur aut eo ipso fallunt quod quaerenda sunt. 
XV. Sempre que não entram em guerras ${ }^{36}$, não gastam muito tempo com caçadas, mais com ócio, entregues a sono e comida; aquele mais forte e belicoso nada faz, administração de casa, lar e campos delegada às mulheres e velhos e àquele mais infirme da família; eles mesmos vadiam, extraordinária sua inconstância de temperamento, visto que ao mesmo tempo os homens assim amam a indolência e odeiam a quietude. 2. É costume dos povos oferecer aos líderes, voluntariamente e por cabeça, gado ou grãos, o que, aceito como honra, também atende às necessidades. 3. Regozijam-se em particular com regalos das gentes vizinhas, os quais são enviados não apenas por indivíduos mas também pela comunidade, corcéis escolhidos, armas magníficas, fáleras ${ }^{37}$ e torques ${ }^{38}$; já ensinamo-los a aceitar também dinheiro.

XVI. Sabe-se bem que os povos dos germanos não habitam cidade alguma, que nem mesmo suportam residências unidas entre si; vivem distantes e dispersos, conforme fonte, conforme campo, conforme bosque tenha agradado. 2. Arranjam vilas não ao nosso costume, com construções contíguas e interligadas: cada um circunda sua casa com espaço livre, seja por precaução contra incêndio, seja por inabilidade em edificar. 3. Nem mesmo há o uso de cantarias ou tijolos entre eles: para tudo empregam madeira ${ }^{39}$, informe e sem beleza ou deleite. Revestem determinados locais mais diligentemente com terra tão pura e brilhante que imita pintura e características das cores. 4. Costumam também abrir buracos subterrâneos e cobrem-nos com muito estrume por cima, abrigo do inverno e depósito às colheitas, porque locais ao modo deste suavizam o rigor do frio, e, se quando inimigo chega devasta o aberto, o escondido e escavado ou é ignorado ou oculta a si mesmo, pois deve ser procurado ${ }^{40}$.

\footnotetext{
${ }^{36}$ O sujeito é ainda os comites, "companheiros", os príncipes, "líderes", e não os germanos em geral.

${ }^{37}$ Fálera: disco feito de ouro, prata ou bronze dado aos soldados romanos como condecoração militar e por eles usado como medalha no peitoral de suas armaduras.

${ }^{38}$ Torque: colar feito de ouro, prata ou bronze utilizado como condecoração militar, em especial entre as populações de cultura celta.

39 Sabe-se que madeira não era o único material empregado; empregavam também, mesmo que parcialmente, pedra e outros materiais.

${ }^{40}$ Uma antítese retórica para finalizar o capítulo.
} 
XVII. Tegumen omnibus sagum fibula aut, si desit, spina consertum: cetera intecti totos dies iuxta focum atque ignem agunt. locupletissimi veste distinguuntur non fluitante, sicut Sarmatae ac Parthi, sed stricta et singulos artus exprimente. 2. gerunt et ferarum pelles, proximi ripae neglegenter, ulteriores exquisitius, ut quibus nullus per commercia cultus. eligunt feras et detracta velamina spargunt maculis pellibusque beluarum, quas exterior Oceanus atque ignotum mare gignit. 3. nec alius feminis quam viris habitus, nisi quod feminae saepius lineis amictibus velantur eosque purpura variant, partemque vestitus superioris in manicas non extendunt, nudae brachia ac lacertos; sed et proxima pars pectoris patet.

XVIII. Quamquam severa illic matrimonia, nec ullam morum partem magis laudaveris. nam prope soli barbarorum singulis uxoribus contenti sunt, exceptis admodum paucis, qui non libidine sed ob nobilitatem plurimis nuptiis ambiuntur. 2. dotem non uxor marito, sed uxori maritus offert. intersunt parentes et propinqui ac munera probant, munera non ad delicias muliebres quaesita nec quibus nova nupta comatur, sed boves et frenatum equum et scutum cum framea gladioque. 3. in haec munera uxor accipitur, atque in vicem ipsa armorum aliquid viro adfert: hoc maximum vinculum, haec arcana sacra, hos coniugales deos arbitrantur. 4. ne se mulier extra virtutum cogitationes extraque bellorum casus putet, ipsis incipientis matrimonii auspiciis admonetur venire se laborum periculorumque sociam, idem in pace, idem in proelio passuram ausuramque: hoc iuncti boves, hoc paratus equus, hoc data arma denuntiant. sic vivendum, sic pariendum: accipere se quae liberis inviolata ac digna reddat, quae nurus accipiant rursusque ad nepotes referantur. 
XVII. Vestimenta de todos, sago $^{41}$ preso com broche ou, se este falta, osso; por outro lado, passam dias inteiros junto da lareira e fogo, descobertos. Os mais ricos distinguemse não por veste ${ }^{42}$ larga como a do sármata e parto, mas justa e moldando cada membro. 2. Usam também peles de animais, os próximos da margem ${ }^{43}$ negligentemente, os do interior mais cuidadosamente, já que, para eles, por comércio nenhum adorno. Escolhem os animais e matizam a pele retirada com malhas do pelame das feras que o Oceano mais distante e o mar desconhecido engendra. 3. E não é outra a aparência das mulheres àquela dos homens, senão que as mulheres se cobrem, mais frequentemente, com mantos de linho e os diversificam com púrpura, e não estendem a parte superior do vestido em mangas, nus braços e antebraços; ora, também parte próxima do peito aparece.

XVIII. Entretanto, matrimônio lá é rigoroso, e nenhum aspecto de seus costumes elogiarse-ia mais; pois são praticamente os únicos, dentre os bárbaros, contentes com uma esposa, excetuados mui poucos que, não por desejo mas por nobreza, são cobiçados por muitos casamentos. 2. Dote ${ }^{44}$ não oferece esposa ao marido, mas marido à esposa. Interpõem-se pais e parentes e apreciam os presentes, presentes requeridos não para mimos femininos, nem com eles se adorna a nova noiva, mas bois e cavalo bridado e escudo com frâmea e gládio. 3. Sob estes presentes recebe-se a esposa e, em troca, ela própria entrega alguma das armas ao homem; julgam este o maior vínculo, estes os misteriosos ritos, estes os deuses conjugais. 4. Para que a mulher não se considere além das aspirações da virtude e além dos acasos das guerras, é lembrada, pelos próprios preâmbulos do matrimônio a se iniciar, que ela se torna companheira nos labores e perigos, e tolerará e empreenderá o mesmo na paz, o mesmo na peleja: isto os bois jungidos, isto o cavalo preparado, isto a arma dada denunciam. Assim deve viver, assim deve procriar: que outorgue aos filhos o que ela receber, inviolado e digno, o que as noras vêm a receber e, por sua vez, é repassado aos netos.

\footnotetext{
${ }^{41}$ Manto feito de lã, cujo comprimento variava de acordo com a estação. Era preso no ombro direito e deixava os braços à mostra.

${ }^{42}$ Esta veste consistia, possivelmente, de uma túnica ou camisa de manga longa e canças.

${ }^{43}$ Provavelmente, Tácito se refere ás margens dos rios Reno e Danúbio.

${ }^{44}$ J. G. C. Anderson (1997, p. 110) sugere que não se oferecia dote, mas presente ao pai da noiva, de modo a adquiria o patria potestas sobre ela.
} 
XIX. Ergo saepta pudicitia agunt, nullis spectaculorum illecebris, nullis conviviorum irritationibus corruptae. litterarum secreta viri pariter ac feminae ignorant. 2. paucissima in tam numerosa gente adulteria, quorum poena praesens et maritis permissa: abscisis crinibus nudatam coram propinquis expellit domo maritus ac per omnem vicum verbere agit; publicatae enim pudicitiae nulla venia: non forma, non aetate, non opibus maritum invenerit. 3. nemo enim illic vitia ridet, nec corrumpere et corrumpi saeculum vocatur. melius quidem adhuc eae civitates, in quibus tantum virgines nubunt et cum spe votoque uxoris semel transigitur. 4. sic unum accipiunt maritum quo modo unum corpus unamque vitam, ne ulla cogitatio ultra, ne longior cupiditas, ne tamquam maritum sed tamquam matrimonium ament. 5. numerum liberorum finire aut quemquam ex agnatis necare flagitium habetur, plusque ibi boni mores valent quam alibi bonae leges.

XX. In omni domo nudi ac sordidi in hos artus, in haec corpora, quae miramur, excrescunt. sua quemque mater uberibus alit, nec ancillis ac nutricibus delegantur. 2 . dominum ac servum nullis educationis deliciis dignoscas: inter eadem pecora, in eadem humo degunt, donec aetas separet ingenuos, virtus agnoscat. 3. sera iuvenum venus, eoque inexhausta pubertas. nec virgines festinantur; eadem iuventa, similis proceritas: pares validaeque miscentur, ac robora parentum liberi referunt. 4. sororum filiis idem apud avunculum qui apud patrem honor. quidam sanctiorem artioremque hunc nexum sanguinis arbitrantur et in accipiendis obsidibus magis exigunt, tamquam et animum firmius et domum latius teneant. 5. heredes tamen successoresque sui cuique liberi, et nullum testamentum. si liberi non sunt, proximus gradus in possessione fratres, patrui, avunculi. quanto plus propinquorum, quanto maior adfinium numerus, tanto gratiosior senectus; nec ulla orbitatis pretia. 
XIX. Vivem, pois, em cercada pudicícia, corrompidas por nenhum encantamento de espetáculos, nenhuma incitação de convívios. Os segredos dos bilhetes ignoram os homens e do mesmo modo as mulheres ${ }^{45}$. 2. Adultérios em tão numerosa gente pouquíssimos, cuja pena é imediata e concedida aos maridos: cortados os cabelos, a expulsa nua de casa, diante dos parentes, o marido, e a conduz vergasta por toda vila à vergasta. De fato, à pudicícia prostituída nenhuma concessão: nem por beleza, nem por idade, nem por riquezas encontraria marido. 3. Lá ninguém ri dos vícios, nem se denomina última moda corromper e ser corrompido. Melhor os povos nos quais somente virgens casam e se consume uma vez só expectativa e voto de esposa. 4. Assim, recebem um marido do mesmo modo que um corpo e uma vida, de forma que não há pensamento além, que não há desejo afora, que não amam, digamos, o marido, mas como que o matrimônio. 5. Tem-se por desonra limitar número de filhos ou matar algum dos agnados, e mais valem ali bons costumes que alhures boas leis.

XX. Em toda casa crescem nus e sujos até aqueles membros, até aqueles corpos que admiramos. Cada qual sua mãe alimenta com os peitos, e não são entregues a criadas e amas. 2. Não se distingue senhor e servo por quaisquer mimos de educação: vivem entre as mesmas greis, no mesmo chão, até que idade separe os livres, valor os reconheça. 3. Tardio o amor entre jovens, a quem viço inesgotável. Nem as virgens são apressadas: mesma juventude, símile estatura; unem-se idênticos e vigorosos, e os rebentos repetem a robustez dos pais. 4. Aos filhos das irmãs, mesma honra junto ao tio materno que junto ao pai. Alguns julgam este o laço de sangue mais sagrado e estreito e exigem-no ao tomar reféns, de modo que retenham tanto, mais firmemente, a disposição como, mais amplamente, a casa. 5. Todavia, herdeiros e sucessores de cada um, os filhos, e não há testamento algum. Se não há filhos ${ }^{46}$, próximo grau quanto à posse, irmãos, tios paternos, tios maternos. Quanto mais parentes, quanto maior o número de afins, tanto mais favorável a velhice, e nenhum o preço de não ter descendente.

\footnotetext{
${ }^{45}$ Alusão às correspondências de amor clandestinas comuns em Roma. Ver, por exemplo, Juv. 6. 277.

${ }^{46}$ Isto é, filhos homens, pois as mulheres não podiam tomar posse da herança móvel ou imóvel, pois esta pertencia à família, da qual as mulheres se apartavam depois do casamento.
} 
XXI. Suscipere tam inimicitias seu patris seu propinqui quam amicitias necesse est. nec implacabiles durant: luitur enim etiam homicidium certo armentorum ac pecorum numero recipitque satisfactionem universa domus, utiliter in publicum, quia periculosiores sunt inimicitiae iuxta libertatem.

2. Convictibus et hospitiis non alia gens effusius indulget. quemcumque mortalium arcere tecto nefas habetur; pro fortuna quisque apparatis epulis excipit. cum defecere, qui modo hospes fuerat, monstrator hospitii et comes; proximam domum non invitati adeunt. 3. nec interest: pari humanitate accipiuntur. notum ignotumque quantum ad ius hospitis nemo discernit. abeunti, si quid poposcerit, concedere moris; et poscendi in vicem eadem facilitas. gaudent muneribus, sed nec data imputant nec acceptis obligantur. [victus inter hospites comis.]

XXII. Statim e somno, quem plerumque in diem extrahunt, lavantur, saepius calida, ut apud quos plurimum hiems occupat. lauti cibum capiunt: separatae singulis sedes et sua cuique mensa. tum ad negotia nec minus saepe ad convivia procedunt armati. 2. diem noctemque continuare potando nulli probrum. crebrae, ut inter vinolentos, rixae raro conviciis, saepius caede et vulneribus transiguntur. 3. sed et de reconciliandis invicem inimicis et iungendis adfinitatibus et adsciscendis principibus, de pace denique ac bello plerumque in conviviis consultant, tamquam nullo magis tempore aut ad simplices cogitationes pateat animus aut ad magnas incalescat. 4. gens non astuta nec callida aperit adhuc secreta pectoris licentia loci; ergo detecta et nuda omnium mens. postera die retractatur, et salva utriusque temporis ratio est: deliberant dum fingere nesciunt, constituunt dum errare non possunt. 
XXI. É mister tanto inimizade do pai ou parente quanto amizade assumir. Não perduram porém implacáveis: de fato, até mesmo homicídio é pago por número de gados e greis determinado, e recebe reparação a casa toda, em benefício do público, porque mais perigosas são inimizades junto da liberdade.

2. A convívios e hospitalidades nenhuma outra gente se entrega de modo mais efusivo. É tido por sacrilégio afastar de seu teto qualquer dos mortais; de acordo com seus meios, cada um acolhe-o com aparatos banquetes ${ }^{47}$. Quando faltar, o que fora apenas anfitrião, guia do hóspede e companheiro; dirigem-se, não convidados, à próxima casa. 3. Mas não faz diferença: são aceitos com igual humanidade. Conhecido e desconhecido, quanto ao direito de hóspede, ninguém discerne. Ao que parte, se ele pedir algo, é de costume conceder, e há mesma facilidade em pedir em troca. Regozijam-se com presentes, mas não cobram os dados nem se obrigam pelos aceitos. [A relação entre anfitrião e hóspede é cortês. $]^{48}$

XXII. Logo após o sono, o qual prolongam, geralmente, dia adentro, se lavam, mais frequentemente, com água quente, já que, entre eles, inverno ocupa maior período. Lavados, fazem refeição, cadeiras a cada um acantoadas e a cada qual a sua mesa; então, armados, procedem aos negócios ou, de modo não menos frequente, a convívios. 2. Seguir bebendo por dia e noite, vergonha a ninguém. Praxe entre vinolentos, repetidas rixas são raramente findadas por insultos, mais frequentemente por matança e feridas. 3. Mas também deliberam nos convívios acerca de mútuo reconciliar entre inimigos, de acertar casamentos, de apontar comandantes, acerca de paz e guerra por fim, como se em mais nenhum outro momento a mente se abrisse a pensamentos francos ou se aquecesse aos grandes. 4. Gente não astuta nem prudente, lá desvela os segredos do peito, por licença da ocasião; o caráter de todos, pois, exposto e desnudo. No dia seguinte retoma-se, e está a salvo o interesse de cada circunstância: discutem enquanto não sabem fingir, decidem enquanto não podem errar.

\footnotetext{
${ }^{47}$ Isto é, com banquetes organizados com pompa.

${ }^{48}$ Acredita-se que esta seja uma inserção posterior.
} 
XXIII. Potui humor ex hordeo aut frumento, in quandam similitudinem vini corruptus; proximi ripae et vinum mercantur. cibi simplices, agrestia poma, recens fera aut lac concretum: sine apparatu, sine blandimentis expellunt famem. adversus sitim non eadem temperantia. 2. si indulseris ebrietati suggerendo quantum concupiscunt, haud minus facile vitiis quam armis vincentur.

XXIV. Genus spectaculorum unum atque in omni coetu idem: nudi iuvenes, quibus id ludicrum est, inter gladios se atque infestas frameas saltu iaciunt. 2. exercitatio artem paravit, ars decorem, non in quaestum tamen aut mercedem: quamvis audacis lasciviae pretium est voluptas spectantium. 3. aleam, quod mirere, sobrii inter seria exercent, tanta lucrandi perdendive temeritate, ut, cum omnia defecerunt, extremo ac novissimo iactu de libertate ac de corpore contendant. 4. victus voluntariam servitutem adit; quamvis iuvenior, quamvis robustior, alligari se ac venire patitur. ea est in re prava pervicacia; ipsi fidem vocant. servos condicionis huius per commercia tradunt, ut se quoque pudore victoriae exsolvant. 
XXIII. Para beber, líquido da cevada ou trigo ${ }^{49}$, fermentado à certa semelhança do vinho; os próximos da margem comerciam também o vinho. Os alimentos são frugais, frutos silvestres, caça fresca ou leite coalhado. Afastam a fome sem aparato, sem condimentos; contra a sede, temperança outra. 2. Se fores complacente com sua embriaguez, fornecendo o quanto desejam, serão vencidos mais facilmente pelos vícios que por armas.

XXIV. O gênero de espetáculos, um, e em toda reunião o mesmo: jovens nus, aos quais isto é brincadeira, lançam-se aos saltos entre gládios e frâmeas apontadas. 2. Exercício gerou arte, arte, graça, todavia não por ganho ou pagamento: de qualquer modo, recompensa da audaz diversão é prazer dos espectadores. 3. Jogo de azar, é de se admirar, praticam sóbrios entre coisas sérias, com tamanha temeridade no ganhar ou perder que, quando desperdiçaram tudo, se medem às expensas de sua liberdade e de seu corpo em último e derradeiro lance. 4. O perdedor segue para a servidão voluntária; embora mais jovem, embora mais robusto, deixa-se amarrar e vender. Esta é a obstinação na questão viciosa; os próprios chamam-na fidelidade. Cedem via comércio servos desta condição para que também eles se livrem da vergonha da vitória.

\footnotetext{
${ }^{49}$ Isto é, cerveja.
} 
$\mathrm{XXV}$. Ceteris servis non in nostrum morem descriptis per familiam ministeriis utuntur: suam quisque sedem, suos penates regit. frumenti modum dominus aut pecoris aut vestis ut colono iniungit, et servus hactenus paret; cetera domus officia uxor ac liberi exequuntur. 2. verberare servum ac vinculis et opere coercere rarum: occidere solent, non disciplina et severitate, sed impetu et ira, ut inimicum, nisi quod impune est. 3. liberti non multum supra servos sunt, raro aliquod momentum in domo, numquam in civitate, exceptis dumtaxat iis gentibus quae regnantur. ibi enim et super ingenuos et super nobiles ascendunt: apud ceteros impares libertini libertatis argumentum sunt.

XXVI. Faenus agitare et in usuras extendere ignotum; ideoque magis servatur quam si vetitum esset. agri pro numero cultorum ab universis in vices occupantur, quos mox inter se secundum dignationem partiuntur; facilitatem partiendi camporum spatia praestant. 2. arva per annos mutant, et superest ager. nec enim cum ubertate et amplitudine soli labore contendunt, ut pomaria conserant, ut prata separent, ut hortos rigent: sola terrae seges imperatur. 3. unde annum quoque ipsum non in totidem digerunt species: hiems et ver et aestas intellectum ac vocabula habent, autumni perinde nomen ac bona ignorantur. 
XXV. Os demais servos eles empregam não ao nosso costume, tarefas por entre a família determinadas $^{50}$ : cada um rege sua residência, seus lares. Senhor exige, como do colono ${ }^{51}$, quantidade de cereal, ou de grei ou de veste, e servo obedece até aí; dos demais serviços de casa ocupam-se esposa e filhos. 2. Vergastar servo e coagi-lo com grilhões e trabalho, raro: costumam matá-los, não por disciplina ou severidade, mas por ímpeto e ira, tal como inimigo, exceto que é impune. 3. Os libertos não estão muito acima dos servos, raro algum peso na casa, nunca no povo, excetuadas tão-só as gentes que são reinadas ${ }^{52}$. De fato, lá ascendem sobre homens-livres e nobres; entre os demais, os libertos desiguais são prova da liberdade.

XXVI. Desconhecido explorar patrimônio e aumentá-lo na usura, e a isso presta-se mais atenção do que se fosse proibido. Os campos são ocupados em turnos, de acordo com o número de cultivadores do todo, os quais são depois distribuídos entre eles segundo dignidade; as extensões dos campos garantem facilidade ao distribuir. 2. Trocam as searas ano a ano, e ainda abunda a gleba. Mas de fato não disputam, através do trabalho, com a fertilidade e amplitude do solo, de modo a plantar pomares, a separar prados, a irrigar hortas: da terra é exigida unicamente colheita. 3. Daí que também não dividem o próprio ano em tantas partes: inverno e verão e primavera possuem significado e termos; nome e benefícios do outono são igualmente ignorados.

\footnotetext{
${ }^{50} \mathrm{Ou}$ seja, os escravos entre os germanos não eram utilizados para a realização dos serviços domésticos.

${ }^{51}$ I. e., da mesma forma que o senhor de terras romano exige do colonus.

52 Isto pois os libertos podiam alcançar proeminência no serviço ao rei, pois dele dependentes e mais solícitos às atividades servis que nobres e homens-livres.
} 
XXVII. Funerum nulla ambitio: id solum observatur ut corpora clarorum virorum certis lignis crementur. 2. struem rogi nec vestibus nec odoribus cumulant: sua cuique arma, quorundam igni et equus adicitur. sepulcrum caespes erigit: monumentorum arduum et operosum honorem ut gravem defunctis aspernantur. lamenta ac lacrimas cito, dolorem et tristitiam tarde ponunt. feminis lugere honestum est, viris meminisse.

3. Haec in commune de omnium Germanorum origine ac moribus accepimus: nunc singularum gentium instituta ritusque quatenus differant, quaeque nationes e Germania in Gallias commigraverint, expediam.

XXVIII. Validiores olim Gallorum res fuisse summus auctorum divus Iulius tradit; eoque credibile est etiam Gallos in Germaniam transgressos. quantulum enim amnis obstabat quo minus, ut quaeque gens evaluerat, occuparet permutaretque sedes promiscas adhuc et nulla regnorum potentia divisas! 2. igitur inter Hercyniam silvam Rhenumque et Moenum amnes Helvetii, ulteriora Boii, Gallica utraque gens, tenuere. manet adhuc Boihaemi nomen signatque loci veterem memoriam quamvis mutatis cultoribus. 3. sed utrum Aravisci in Pannoniam ab Osis [Germanorum natione] an Osi ab Araviscis in Germaniam commigraverint, cum eodem adhuc sermone institutis moribus utantur, incertum est, quia pari olim inopia ac libertate eadem utriusque ripae bona malaque erant. 4. Treveri et Nervii circa adfectationem Germanicae originis ultro ambitiosi sunt, tamquam per hanc gloriam sanguinis a similitudine et inertia Gallorum separentur. ipsam Rheni ripam haud dubie Germanorum populi colunt, Vangiones, Triboci, Nemetes. 5. ne Ubii quidem, quamquam Romana colonia esse meruerint ac libentius Agrippinenses conditoris sui nomine vocentur, origine erubescunt, transgressi olim et experimento fidei super ipsam Rheni ripam collocati, ut arcerent, non ut custodirentur. 
XXVII. Nos funerais nenhuma pompa: apenas isso é observado, que os corpos dos homens preclaros sejam cremados com determinada lenha. 2. Não cumulam a pilha da pira de vestes nem perfumes: armas de cada um são acrescentadas ao fogo, também o cavalo de alguns. Turfa erige o sepulcro ${ }^{53}$ : desdenham da honra de elevados e laboriosos monumentos como peso aos falecidos. Afastam lamentos e lágrimas rapidamente, dor e tristeza lentamente. É adequado às mulheres prantear, aos homens recordar.

3. No geral, aprendemos isto da origem e costumes dos germanos como um todo; agora mostrarei até que ponto diferem as instituições e ritos de cada uma das gentes, e quais nações migraram da Germânia às Gálias ${ }^{54}$.

XXVIII. O maior dos autores, o divino Júlio ${ }^{55}$, transmite que outrora o poder dos gauleses foi mais robusto; daí se crê que também os gauleses atravessaram à Germânia. Ora, quão pouco obstava torrente para que, quando alguma gente prevalecia, ela não ocupasse e permutasse regiões até então em comum e por nenhuma influência de reinos divididas! 2. Assim sendo, os helvécios ocuparam entre a floresta Hercínia ${ }^{56}$ e os rios Reno e Meno, os boios o interior, uma e outra gente gálica. Lá o nome Boiemo ${ }^{57}$ permanece e assinala a antiga história do local, por mais que mudados os habitantes. 3. Mas se os araviscos migraram à Panônia desde os osos, [nação de germanos $]^{58}$, ou osos desde os araviscos à Germânia - já que ainda empregam mesmo idioma, instituições, costumes - é incerto, porque outrora havia pobreza igual e mesma liberdade e em ambas as margens do bom e do ruim. 4. Os tréveros e os nérvios são deveras ostensivos quanto a sua aspiração à origem germânica, como se por esta glória de sangue se separassem da semelhança e indolência dos gaulesess. Habitam a própria margem do Reno os vangiões, tribocos, nemetes, povos dos germanos sem dúvida. 5. Nem mesmo os úbios, apesar de terem logrado ser colônia romana e de preferirem ser chamados de agripinenses, do nome de seu fundador, enrubescem pela origem; outrora atravessaram e, pela prova de sua

\footnotetext{
53 Montes funerários de turfa, datados dessa época e além, são ainda escontrados, em especial na Escandinávia.

${ }^{54}$ Aqui termina o relato considerado mais etnográfico pelos estudiosos, e também aquela que é considerada a primeira parte do texto de Tácito.

${ }^{55}$ Referência a Júlio César e sua De Bello Gallico, em especial à passagem 6. 24. 1.

${ }^{56}$ A floresta Hercínia se estendia da margem oriental do rio Reno, através do sul da atual Alemanha, até a Bohêmia e os Cárpatos.

57 "O país dos boios". O nome permanece até nossos dias, correnpondendo à região da Bohêmia, parte da atual República Tcheca.

${ }^{58}$ Provável interpolação posterior.
} 
fidelidade, foram assentados sobre a própria margem do Reno para que repelissem, não para que fossem resguardados. 
XXIX. Omnium harum gentium virtute praecipui Batavi non multum ex ripa, sed insulam Rheni amnis colunt, Chattorum quondam populus et seditione domestica in eas sedes transgressus in quibus pars Romani imperii fierent. 2. manet honos et antiquae societatis insigne; nam nec tributis contemnuntur nec publicanus atterit; exempti oneribus et collationibus et tantum in usum proeliorum sepositi, velut tela atque arma, bellis reservantur. 3. est in eodem obsequio et Mattiacorum gens; protulit enim magnitudo populi Romani ultra Rhenum ultraque veteres terminos imperii reverentiam. ita sede finibusque in sua ripa, mente animoque nobiscum agunt, cetera similes Batavis, nisi quod ipso adhuc terrae suae solo et caelo acrius animantur.

4. Non numeraverim inter Germaniae populos, quamquam trans Rhenum Danuviumque consederint, eos qui Decumates agros exercent: levissimus quisque Gallorum et inopia audax dubiae possessionis solum occupavere; mox limite acto promotisque praesidiis sinus imperii et pars provinciae habentur.

XXX. Ultra hos Chatti initium sedis ab Hercynio saltu incohant, non ita effusis ac palustribus locis ut ceterae civitates in quas Germania patescit, durant siquidem colles, paulatim rarescunt, et Chattos suos saltus Hercynius prosequitur simul atque deponit. 2. duriora genti corpora, stricti artus, minax vultus et maior animi vigor. multum, ut inter Germanos, rationis ac sollertiae: praeponere electos, audire praepositos, nosse ordines, intellegere occasiones, differre impetus, disponere diem, vallare noctem, fortunam inter dubia, virtutem inter certa numerare, quodque rarissimum nec nisi Romanae disciplinae concessum, plus reponere in duce quam in exercitu. 3. omne robur in pedite, quem super arma ferramentis quoque et copiis onerant: alios ad proelium ire videas, Chattos ad bellum. rari excursus et fortuita pugna. equestrium sane virium id proprium, cito parare victoriam, cito cedere: <peditum> velocitas iuxta formidinem, cunctatio propior constantiae est. 
XXIX. Em valor dentre todas estas gentes primeiros, os batavos habitam não muito da margem, mas ilha do rio Reno ${ }^{59}$; antes o povo dos catos atravessaram, por sedição interna, a estas regiões, nas quais se tornaram parte do império romano. 2. Permanece a honra e insígnia da antiga aliança ${ }^{60}$, pois não são desdenhados por tributos nem publicano os enfraquece; isentos de taxações e arrecadações e tão apropriados ao exercício das pelejas, tal como flechas e armas, são reservados às guerras. 3. Em igual lealdade vive a gente dos matiacos ${ }^{61}$; de fato, estendeu a grandeza do povo romano a reverência ao império para além do Reno e além dos antigos limites. Assim, quanto à região e fronteiras vivem em sua margem, à mente e ânimo, conosco; de resto, símiles aos batavos, senão que, pelo próprio solo e clima de sua terra, animam-se inda mais agudos.

4. Não enumeraria entre os povos da Germânia, apesar de terem se assentado além do Reno e Danúbio, os que trabalham os campos decúmanos ${ }^{62}$ : todos os mais baixos dos gauleses, audazes pela pobreza, ocuparam o solo de posse incerta; depois, o limite traçado e avançadas as guarnições, são tidos como extremidade do império e parte da província.

XXX. Para além destes os catos dão início às suas habitações a partir do bosque Hercíno ${ }^{63}$, em locais não tão abertos e pantanosos como as demais povos aos quais a Germânia se estende, já que montanhas se prolongam, paulatinamente rareiam, e ao mesmo tempo o bosque Hercínia acompanha e assenta seus catos. 2. Os corpos da gente, os mais resistentes, membros estreitos, expressão minaz e vigor da mente o maior. Para germanos, muita razão e astúcia: designam comandantes eleitos, ouvem os designados, conhecem as linhas, percebem as oportunidades, dispersam os ataques, organizam o dia, entrincheiram à noite, enumeram a fortuna entre o dúbio, o valor entre o certo, e o que é raríssimo e concedido senão à disciplina romana, fiam-se mais no general que no exército. 3. Toda força na infantaria, a qual carregam também com ferramentas e suprimentos, além das armas: vê-se outros irem ao combate, os catos à guerra. Raras as incursões e a batalha

\footnotetext{
${ }^{59}$ Ilha formada em uma bifurcação do antigo rio Reno, próxima a Utrecht e Leiden, Holanda.

${ }^{60}$ Sabe-se que os batavos lutaram ao lado dos romanos desde, ao menos, 12 a. C e que, após a desistência da conquista da Germânia, formaram um estado-cliente de Roma.

${ }^{61}$ Possivelmente parte dos catos, os matiacos passaram à suserania romana durante a campanha de Druso, em 2 a. C, seu território fazendo parte da fronteira do Império. Participaram da chamada "Revolta dos Batavos" em 69 d. C.

62 Única referência conhecida aos agri decumates. De etmologia obscura e incerta, o nome corresponde à região que era parte das províncias romanas da germania superior e da raetia; englobava partes da Floresta Negra, Alpes Suábios, Alpes Francônios e dos rios Reno, Meno e Danúbio.

63 Tácito se refere a uma parte específica da floresta Hercínia, daí o uso de saltus, e não silua, como antes. Este trecho da floresta corresponde à região das cadeias de montanhas de Vogelsberg e Rhön, na Alemanha central.
} 
fortuita. Isto, sem dúvida próprio da força dos cavaleiros, rapidamente obter vitória, rapidamente retirar-se: a velocidade dos infantes está ao lado do pânico, a demora mais perto da firmeza. 
XXXI. Et aliis Germanorum populis usurpatum raro et privata cuiusque audentia apud Chattos in consensum vertit, ut primum adoleverint, crinem barbamque submittere, nec nisi hoste caeso exuere votivum obligatumque virtuti oris habitum. 2. super sanguinem et spolia revelant frontem, seque tum demum pretia nascendi rettulisse dignosque patria ac parentibus ferunt; ignavis et imbellibus manet squalor. 3. fortissimus quisque ferreum insuper anulum (ignominiosum id genti) velut vinculum gestat, donec se caede hostis absolvat. 4. plurimis Chattorum hic placet habitus, iamque canent insignes et hostibus simul suisque monstrati. omnium penes hos initia pugnarum; haec prima semper acies, visu nova: nam ne in pace quidem vultu mitiore mansuescunt. 5. nulli domus aut ager aut aliqua cura: prout ad quemque venere, aluntur, prodigi alieni, contemptores sui, donec exsanguis senectus tam durae virtuti impares faciat.

XXXII. Proximi Chattis certum iam alveo Rhenum quique terminus esse sufficiat Usipi ac Tencteri colunt. 2. Tencteri super solitum bellorum decus equestris disciplinae arte praecellunt; nec maior apud Chattos peditum laus quam Tencteris equitum. 3. sic instituere maiores, posteri imitantur. hi lusus infantium, haec iuvenum aemulatio: perseverant senes. 4. inter familiam et penates et iura successionum equi traduntur: excipit filius, non ut cetera, maximus natu, sed prout ferox bello et melior. 
XXXI. Além disso, o que é praticado por outros povos de germanos, raramente e por intrepidez particular de cada um, tornou-se consenso entre os catos: tão logo tenham adolescido, deixar crescer cabelo e barba e, senão quando morto o inimigo, tirar a feição da face, votiva e empenhada pelo valor. 2. Sobre sangue e espólios desvelam a face, e somente então eles restituíram o débito de seu nascer e são dignos de pátria e pais; aos ignavos e imbeles permanece a vergonha. 3. Aquele mais forte usa, além do mais, anel de ferro, algo ignominioso à gente, tal como grilhão, até que se liberte por matança de inimigo. 4. A muitos catos agrada esta feição, e até encanecem marcados, notáveis aos inimigos bem como aos seus. Com eles, o início de todas pelejas, sempre esta a primeira linha, singular visão, pois nem mesmo na paz abrandam para aparência mais suave. 5. A nenhum casa ou campo ou qualquer preocupação: sempre que vêm a alguém, são alimentados, pródigos do alheio, desdenhadores do seu, até que exangue velhice faça deles impotentes para tão dura virtude.

XXXII. Próximos ${ }^{64}$ aos catos, onde o Reno já está definido por seu leito de modo que forneça fronteira, habitam os usipos e tenteros. 2. Os tenteros excedem, além da usual glória nas guerras, na arte da cavalaria, e a reputação dos infantes entre os catos não é maior que a dos cavaleiros dos tenteros. 3. Assim instituíram os antepassados, os pósteros imitam. Isto, brincadeira das crianças, esta a emulação dos jovens, nisso perseveram os velhos. 4. Entre casa, propriedade e direitos de herança, são transmitidos os cavalos: não os recebe o filho mais velho, como o restante, mas o mais fero e melhor na guerra.

\footnotetext{
${ }^{64}$ Ao norte dos catos.
} 
XXXIII. Iuxta Tencteros Bructeri olim occurrebant: nunc Chamavos et Angrivarios immigrasse narratur, pulsis Bructeris ac penitus excisis vicinarum consensu nationum, seu superbiae odio seu praedae dulcedine seu favore quodam erga nos deorum; nam ne spectaculo quidem proelii invidere. 2. super sexaginta milia non armis telisque Romanis, sed, quod magnificentius est, oblectationi oculisque ceciderunt. maneat, quaeso, duretque gentibus, si non amor nostri, at certe odium sui, quando urgentibus imperii fatis nihil iam praestare fortuna maius potest quam hostium discordiam.

XXXIV. Angrivarios et Chamavos a tergo Dulgubnii et Chasuarii claudunt aliaeque gentes haud perinde memoratae, a fronte Frisii excipiunt. maioribus minoribusque Frisiis vocabulum est ex modo virium. utraeque nationes usque ad Oceanum Rheno praetexuntur ambiuntque immensos insuper lacus et Romanis classibus navigatos. 2. ipsum quin etiam Oceanum illa temptavimus; et superesse adhuc Herculis columnas fama vulgavit, sive adiit Hercules, seu quicquid ubique magnificum est, in claritatem eius referre consensimus. 3. nec defuit audentia Druso Germanico, sed obstitit Oceanus in se simul atque in Herculem inquiri. mox nemo temptavit, sanctiusque ac reverentius visum de actis deorum credere quam scire. 
XXXIII. Junto ${ }^{65}$ aos tenteros, os bruteros apresentavam-se outrora: agora relata-se que os camavos e agrivários imigraram quando repelidos os bruteros e completamente liquidados por coalizão de nações vizinhas, seja por aversão à soberba, seja pela doçura da butim, seja, em certa medida, por favor dos deuses para conosco; com efeito, nem mesmo recusaram o espetáculo da peleja 2. Mais de sessenta mil tombaram não por armas e lanças romanas, mas, o que é mais esplêndido, para o deleite de nossos olhos. Que permaneça, suplico, e perdure, senão o amor para conosco, ao menos o ódio para com os seus, visto que, enquanto urgem os fados do império, a fortuna já não pode proporcionar nada maior que a discórdia dos inimigos.

XXXIV. Os dulgúbnos, casuários e outras gentes de tal modo não recordadas encerram por detrás ${ }^{66}$ os angrivários e camavos, à frente ${ }^{67}$ os frísios seguem. São designados frísios maiores e menores em proporção à sua força. Ambas as nações são margeadas até o Oceano pelo Reno e circundam, além do mais, imensos $\operatorname{lagos}^{68}$ navegados por frotas romanas $^{69} .2$. Lá lidamos, ademais, com o próprio Oceano ${ }^{70}$, e rumor propalou que ainda perduram as colunas de Hércules, quer tenha Hércules lá chegado ou tenhamos concordado em atribuir à sua reputação tudo o que é magnífico em todo lugar. 3. E não faltou audácia a Druso Germânico, mas obstou Oceano que se inquirisse dele bem como de Hércules. Depois, ninguém o tentou, e foi considerado mais sagrado e reverencial, acerca dos atos dos deuses, crer que compreender.

\footnotetext{
${ }^{65}$ Isto é, ao norte dos tenteros.

${ }^{66}$ Ao sul.

${ }^{67}$ Ao norte.

${ }^{68}$ Estes lagos se fundiram ao Golfo Zuiderzee após uma inundação ocorrida no séc. XIII.

${ }^{69}$ Aquelas de Druso em 12 a. C, de Tibério em 5 d. C. e Germânico em 15-16 d. C.

${ }^{70} \mathrm{O}$ Oceano está aqui personificado.
} 
XXXV. Hactenus in occidentem Germaniam novimus; in septentrionem ingenti flexu recedit. ac primo statim Chaucorum gens, quamquam incipiat a Frisiis ac partem litoris occupet, omnium quas exposui gentium lateribus obtenditur, donec in Chattos usque sinuetur. 2. tam immensum terrarum spatium non tenent tantum Chauci sed et implent, populus inter Germanos nobilissimus quique magnitudinem suam malit iustitia tueri. 3 . sine cupiditate, sine impotentia, quieti secretique nulla provocant bella, nullis raptibus aut latrociniis populantur. 4. id praecipuum virtutis ac virium argumentum est, quod, ut superiores agant, non per iniurias adsequuntur; prompta tamen omnibus arma ac, si res poscat, exercitus, plurimum virorum equorumque; et quiescentibus eadem fama.

XXXVI. In latere Chaucorum Chattorumque Cherusci nimiam ac marcentem diu pacem inlacessiti nutrierunt; idque iucundius quam tutius fuit, quia inter impotentes et validos falso quiescas: ubi manu agitur, modestia ac probitas nomina superioris sunt. 2. ita qui olim boni aequique Cherusci, nunc inertes ac stulti vocantur; Chattis victoribus fortuna in sapientiam cessit. 3. tracti ruina Cheruscorum et Fosi, contermina gens, adversarum rerum ex aequo socii sunt, cum in secundis minores fuissent. 
XXXV. Até este ponto conhecemos a Germânia em direção ao oeste; ao norte, ela recua com enorme curva ${ }^{71}$. Primeiro a gente dos caucos; apesar de começar a partir dos frísios e ocupar parte do litoral, estende-se pelos flancos de todas as gentes as quais expus, até pender até os catos. 2. Tão imensa extensão de terras os caucos não apenas controlam mas também preenchem, povo entre os germanos nobilíssimo e tal que prefere que sua grandeza seja preservada com justiça. 3. Sem cobiça, sem excesso, quietos e apartados não provocam guerras quaisquer, não devastam ninguém com saques ou assaltos. 4. Esta é a principal prova de seu valor e força, que, para serem superiores, não usam de violências; prestes todavia as armas para todos e, se a situação demanda, o exército de muitos homens e cavalos; e também enquanto em paz a mesma fama.

XXXVI. Ao lado ${ }^{72}$ dos caucos e catos, os queruscos há muito nutriam paz demasiada e enfraquecedora, não atacados; e isso foi mais aprazível que seguro, porque, entre impetuosos e vigorosos, errado aquietar-se: onde se vive no braço moderação e probidade são palavras do vencedor. 2. Assim, os queruscos, outrora os bons e justos, são chamados agora de covardes e de tolos; aos catos vitoriosos fortuna resultou em sapiência. 3. Os fosos, gente vizinha, arrastados pela ruína dos queruscos, são na mesma medida companheiros na adversidade, conquanto fossem inferiores na prosperidade.

\footnotetext{
${ }^{71}$ A "enorme curva" seria a península da Jutlândia.
}

${ }^{72}$ I.e., a leste. 
XXXVII. Eundem Germaniae sinum proximi Oceano Cimbri tenent, parva nunc civitas, sed gloria ingens. veterisque famae lata vestigia manent, utraque ripa castra ac spatia, quorum ambitu nunc quoque metiaris molem manusque gentis et tam magni exitus fidem. 2. sescentesimum et quadragesimum annum urbs nostra agebat, cum primum Cimbrorum audita sunt arma Caecilio Metello ac Papirio Carbone consulibus. ex quo si ad alterum imperatoris Traiani consulatum computemus, ducenti ferme et decem anni colliguntur: tam diu Germania vincitur. 3. medio tam longi aevi spatio multa in vicem damna. non Samnis, non Poeni, non Hispaniae Galliaeve, ne Parthi quidem saepius admonuere: quippe regno Arsacis acrior est Germanorum libertas. 4. quid enim aliud nobis quam caedem Crassi, amisso et ipse Pacoro, infra Ventidium deiectus Oriens obiecerit? 5. at Germani Carbone et Cassio et Scauro Aurelio et Servilio Caepione Maximoque Mallio fusis vel captis quinque simul consulares exercitus populo Romano, Varum tresque cum eo legiones etiam Caesari abstulerunt; nec impune C. Marius in Italia, divus Iulius in Gallia, Drusus ac Nero et Germanicus in suis eos sedibus perculerunt: mox ingentes C. Caesaris minae in ludibrium versae. 6. inde otium, donec occasione discordiae nostrae et civilium armorum expugnatis legionum hibernis etiam Gallias adfectavere, ac rursus pulsi; nam proximis temporibus triumphati magis quam victi sunt.

XXXVIII. Nunc de Suebis dicendum est, quorum non una ut Chattorum Tencterorumve gens; maiorem enim Germaniae partem obtinent, propriis adhuc nationibus nominibusque discreti, quamquam in commune Suebi vocentur. 2. insigne gentis obliquare crinem nodoque substringere: sic Suebi a ceteris Germanis, sic Sueborum ingenui a servis separantur. 3. in aliis gentibus seu cognatione aliqua Sueborum seu, quod saepius accidit, imitatione, rarum et intra iuventae spatium: apud Suebos usque ad canitiem horrentes capilli retorquentur, ac saepe in ipso vertice religantur. 4. principes et ornatiorem habent: ea cura formae, sed innoxia; neque enim ut ament amenturve, in altitudinem quandam et terrorem adituri bella compti [ut] hostium oculis ornantur. 
XXXVII. Controlam o mesmo promontório da Germânia, próximos ao Oceano $^{73}$, os cimbros, povo agora pequeno, mas de enorme glória. Da antiga fama permanecem vastos vestígios, em ambas as margens extensas fortificações, por cuja circunferência se pode ainda agora determinar grandeza e tropa da gente e evidência de tão grande emigração. 2. Nossa cidade vivia seu sexcentésimo quadragésimo ano quando se ouviu pela primeira vez da armada dos cimbros, Cecílio Metelo e Papírio Carbão cônsules ${ }^{74}$. Se contarmos desta data até o segundo consulado do imperador Trajano ${ }^{75}$, se acumulam aproximadamente duzentos e dez anos: há tão muito a Germânia está sendo conquistada. 3. Através de espaço tão longo de tempo, muitas as perdas de cada lado. Nem samnitas, nem fenícios, nem Hispânia ou Gália, nem mesmo partas admoestaram com mais frequência: sem dúvida mais enérgica que o reino de Arsace $^{76}$ é a liberdade dos germanos. 4. De fato, com que outra coisa que não a morte de $\mathrm{Crasso}^{77}$ escarnecer-nos-ia o Oriente, tendo ele próprio perdido Pácoro ${ }^{78}$, caído sob Ventídio ${ }^{79}$ ? 5. Mas os germanos arrebataram, Carbão ${ }^{80}$, Cássio $^{81}$, Escáuro Aurélio ${ }^{82}$, Servílio Cepião ${ }^{83}$ e Máximo Málio ${ }^{84}$ derrotados ou capturados, cinco exércitos consulares ao povo romano ao mesmo tempo; ao César, Varo, e com ele três legiões ${ }^{85}$; e, impunemente, Caio Mário na Itália ${ }^{86}$, divino

\footnotetext{
${ }^{73}$ Ou seja, no extremo norte da península da Jutlândia.

74 O consulado de Metelo e Carbão ocorreu em 113 a. C. Os invasores cimbros chegaram a Roma e avançaram até a província romana de Ilírico, nos Balcãs.

${ }^{75}$ Isto é, até 98 d. C. Esta passagem é importante a fixação da data de composição da Germania.

${ }^{76} \mathrm{Ou}$ seja, o reino dos partas. Arsace foi o fundador deste reino estabelecido em 248 a. C. e que compreendia partes do Oriente Médio, Ásia Central e Cáucaso.

${ }^{77}$ M. Craso, triúnviro, perdeu todo o seu exército e sua vida na Batalha de Carras, travada contra os partas, em 53 a. C.

${ }^{78}$ Pároco, filho do rei parta Orodes, foi derrotado e morto por Ventídio na Síria, em 38 a. C.

${ }^{79}$ P. Ventídio Basso tornou-se cônsul em 43 a. C. e ganhou triunfo em 38 a. C., após expulsar os partas da Síria e da Ásia Menor, as quais ocupavam como conquistadores há cerca de dois anos.

${ }^{80}$ Cneu Papírio Carbão, cônsul derrotado pelos cimbros em Noreia, antiga cidade no atual estado austríaco da Caríntia, em 113 a. C.

${ }^{81}$ L. Cássio Longino, derrotado e morto na Batalha de Burdigala (atual Bordeux) pelos tigurinos, povo helvécio aliado dos cimbros, em 107 a. C.

${ }^{82}$ M. Aurélio Escáuro, legado de Málio Máximo durante a Guerra Cimbra, capturado na Batalha de Araúsio (atualmente Orange, no sudesde francês) em 105 a. C., e depois executado pelo rei Boiorix dos cimbros.

${ }^{83}$ Q. Servílio Cepião, procônsul da Gália Cisalpina em 105 a. C., se recusou a juntar forças com Málio Máximo, um nouus homo, na Batalha de Aráusio, o que levou à completa derrota dos romanos. De volta a Roma, foi julgado e condenado pela perda de seu exército, e terminou sua vida em exílio na Ásia Menor.

${ }^{84}$ Cneu Málio Máximo, um homem novo, foi cônsul em 105 a. C. Derrotado pelos cimbros na Batalha de Aráusio, foi julgado e condenado pela perda de seu exército. Morreu em exílio.

${ }^{85}$ P. Quintílio Varo, general do Imperador Augusto, foi derrotado com suas três legiões pela confederação de povos germânicas liderada por Armínio, o Cherusco, na famosa Batalha da Floresta de Teutoburgo, em 9 d. C.

${ }^{86}$ Caio Mário, político e general romano, derrotou os cimbros e teutões invasores na Batalha de Vercellae, atual Vercilli, no Piemonte, em 102 a. C.
} 
Júlio na Gália ${ }^{87}$, Druso ${ }^{88}$, Nero ${ }^{89}$ e Germânico ${ }^{90}$ em seus próprios territórios, não os sobrepujaram: depois, as enormes ameaças de Caio César transformaram-se em deboche $^{91}$. 6. Calmaria em seguida, até que assaltaram, na ocasião de nossa discórdia e guerra civil, expugnados os acampamentos invernais das legiões, também as Gálias, mas foram rechaçados ${ }^{92}$; com efeito, em tempos recentes foram mais levados em triunfo que vencidos.

XXXVIII. Agora devemos falar sobre os suevos, cuja gente não é uma só como a dos catos ou tenteros; de fato, ocupam a maior parte da Germânia, e são ainda distinguidos por nações e nomes próprios, apesar de serem chamados de suevos no geral. 2. Marca da gente pôr o cabelo para o lado e amarrá-lo com nó: assim os suevos dos germanos restantes, assim os livres dentre os suevos dos servos se separam. 3. Em outras gentes, seja por alguma relação com os suevos seja, o que ocorre mais frequentemente, por imitação, raro e durante a juventude: entre os suevos, até agrisalhar os cabelos ouriçados são postos para trás, e frequentemente são reatados no próprio topo. 4. Os chefes os têm até mais ornados: isto, cuidado com aparência, mas inofensivo, pois não se ornam para amar ou ser amados, mas para os olhos dos inimigos, de modo a crescer e aterrorizar, prestes a ir às guerras.

\footnotetext{
${ }^{87}$ Referência à derrota do rei germânico Ariovisto por César, durante sua campanha na Gália, em 58 a. C. ${ }^{88}$ Druso, irmão de Tibério, promoveu bem sucedidas campanhas durante 12-9 a. C., chegando a alcançar o rio Elba.

${ }^{89}$ Nero, nome de Tibério antes da adoção por Augusto, comandou nove campanhas entre 9 a. C. e $11 \mathrm{~d}$. C.

${ }^{90}$ Germânico, filho de Druso e filho adotivo de Tibério, este em campanha na Germânia de 14 d. C. a 16 d. C.

${ }^{91}$ Tácito está se referindo à expedição de Calígula no Reno, no outono de 39 d. C.

${ }^{92}$ Em 69 d. C., o ano dos quatro imperadores, é data do início da Revolta dos Batavos, sob comando do príncipe romanizado Caio Júlio Civil.
} 
XXXIX. Vetustissimos nobilissimosque Sueborum Semnones memorant; fides antiquitatis religione firmatur. 2. stato tempore in silvam auguriis patrum et prisca formidine sacram <eiusdem > nominis eiusdemque sanguinis populi legationibus coeunt caesoque publice homine celebrant barbari ritus horrenda primordia. 3. est et alia luco reverentia: nemo nisi vinculo ligatus ingreditur, ut minor et potestatem numinis prae se ferens. si forte prolapsus est, attolli et insurgere haud licitum: per humum evolvuntur. 4. eoque omnis superstitio respicit, tamquam inde initia gentis, ibi regnator omnium deus, cetera subiecta atque parentia. adicit auctoritatem fortuna Semnonum: centum pagis habitant, magnoque corpore efficitur ut se Sueborum caput credant.

XL. Contra Langobardos paucitas nobilitat: plurimis ac valentissimis nationibus cincti non per obsequium sed proeliis et periclitando tuti sunt. Reudigni deinde et Aviones et Anglii et Varini et Eudoses et Suarines et Nuitones fluminibus aut silvis muniuntur. 2. nec quicquam notabile in singulis, nisi quod in commune Nerthum, id est Terram matrem, colunt eamque intervenire rebus hominum, invehi populis arbitrantur. est in insula Oceani castum nemus, dicatumque in eo vehiculum, veste contectum; attingere uni sacerdoti concessum. 3. is adesse penetrali deam intellegit vectamque bubus feminis multa cum veneratione prosequitur. laeti tunc dies, festa loca, quaecumque adventu hospitioque dignatur. 4. non bella ineunt, non arma sumunt; clausum omne ferrum; pax et quies tunc tantum nota, tunc tantum amata, donec idem sacerdos satiatam conversatione mortalium deam templo reddat. 5. mox vehiculum et vestis et, si credere velis, numen ipsum secreto lacu abluitur. servi ministrant, quos statim idem lacus haurit. arcanus hinc terror sanctaque ignorantia, quid sit illud quod tantum perituri vident. 
XXXIX. Recordam os semnonos os mais antigos e nobres dos suevos; a crença em sua antiguidade é reforçada pela religião. 2. Em data estabelecida, em floresta sagrada por augúrios dos ancestrais e prisca reverência, os povos de mesmo nome e sangue se reúnem por meio de embaixadores e, morto homem em favor do público, celebram o horrendo início do rito bárbaro. 3. Há também outra reverência ao bosque: ninguém nele ingressa senão atado com corda, como que admitindo para si ser inferior e sujeito ao nume. Se por ventura caiu, não é lícito que seja ajudado ou se levante: rola pelo chão. 4. A superstição como um todo respeita isso, que daí o início da gente, aí o deus de todos soberano, o restante submetido e obediente. A fortuna dos semnonos adiciona autoridade: habitam cem comarcas, e ocorre que por seu grande corpo se creiam a cabeça dos suevos.

XL. Contrariamente, pouquidão enobrece os langobardos: cercados por muitas e valentíssimas nações, defendem-se não por subserviência mas por pelejas e perigo. Em seguida, reudignos, aviones, anglos, varinos, eudoses, suarines e nuítones fortificados por rios ou florestas. 2. Nada notável em cada um, senão que em comum cultuam $\mathrm{Nerto}^{93}$, isto é, a mãe Terra, e julgam que ela intervém nos assuntos dos homens e viaja por entre os povos. Há em ilha do Oceano bosque intocado, e nele veículo consagrado coberto com veste; permitido a um único sacerdote tocá-lo. 3. Ele percebe que a deusa se faz presente no santuário, e conduzida por vacas, prossegue com muita veneração. Dias alegres então, festividades estabelecidas, a todos que ela digna com sua chegada e hospedagem. 4 . Não entram em guerras, não pegam em armas; todo ferro fechado; paz e quietude tão-só então notada, tão-só então amada, até que o mesmo sacerdote retorne ao templo a deusa saciada da conversa dos mortais. 5. Depois veículo, veste e, se quiseres crer, o próprio nume são banhados em lago secreto. Cuidam disso os servos, os quais logo após o mesmo lago engole. Daí misterioso terror e sagrada ignorância: o que é isso que tão-só os que perecerão veem.

\footnotetext{
${ }^{93}$ Deusa decerto conectada ao culto da fertilidade.
} 
XLI. Et haec quidem pars Sueborum in secretiora Germaniae porrigitur: propior, ut, quo modo paulo ante Rhenum, sic nunc Danuvium sequar, Hermundurorum civitas, fida Romanis; eoque solis Germanorum non in ripa commercium, sed penitus atque in splendidissima Raetiae provinciae colonia. 2. passim sine custode transeunt; et cum ceteris gentibus arma modo castraque nostra ostendamus, his domos villasque patefecimus non concupiscentibus. in Hermunduris Albis oritur, flumen inclutum et notum olim; nunc tantum auditur.

XLII. Iuxta Hermunduros Naristi ac deinde Marcomani et Quadi agunt. praecipua Marcomanorum gloria viresque, atque ipsa etiam sedes pulsis olim Boiis virtute parta. nec Naristi Quadive degenerant. eaque Germaniae velut frons est, quatenus Danuvio praecingitur. 2. Marcomanis Quadisque usque ad nostram memoriam reges manserunt ex gente ipsorum, nobile Marobodui et Tudri genus (iam et externos patiuntur), sed vis et potentia regibus ex auctoritate Romana. raro armis nostris, saepius pecunia iuvantur, nec minus valent. 
XLI. Em verdade, esta parte dos suevos se estende no mais remoto da Germânia: mais perto - do mesmo modo que pouco antes o Reno, assim agora sigo o Danúbio - o povo dos hermúnduros é fiel aos romanos, e por isso somente eles dentre os germanos comerciam não só nas margens, mas também interior a fundo e na mais esplêndida colônia da província récia. 2. Atravessam em diferentes lugares e sem guarda; e enquanto apresentamos às demais gentes apenas armas e nossas fortificações, abrimos casas e vilas a eles, não cobiçosos. Nos hermúnduros nasce o Elba, rio renomado e outrora conhecido $^{94}$; agora, dele tão-só se ouve.

XLII. Junto aos hermúnduros vivem os naristos e, em seguida, marcomanos e quados. Particular é a glória e a força dos marcomanos, e sua própria região foi conseguida através de seu valor, repelidos outrora os boios; mas naristos ou quados não desonram. Esta é como que a fronte da Germânia, até onde é envolvida pelo Danúbio. 2. Marcomanos e quados mantiveram reis de sua própria gente até nossa época, a nobre casa de Maroboduo $^{95}$ e de Tudro ${ }^{96}$ - no momento também admitem estrangeiros -, mas força e poder dos reis consoante autoridade romana. Raramente são ajudados por nossas armas, mais frequentemente por dinheiro, mas não são menos fortes.

\footnotetext{
${ }^{94} \mathrm{O}$ rio Elba nasce no nordeste da Bohêmia, que não era compreendida pelo território dos hermúnduros, o qual se estendia da atual Regensburg no Danúbio até a Turíngia.

95 Estabelecido na Bohêmia, o rei Maroboduo um poderoso reino na região. Assumiu posição neutra no confronto entre romano e germanos ocidentais, o que o levou a ser atacado por uma coalisão liderada por Armínio. Refugiou-se sob a custódia de Tibério, e permaneceu em Ravena até sua morte em 36 d. C.

${ }^{96}$ Possivelmente rei dos quados; deste, histórias não restaram.
} 
XLIII. Retro Marsigni, Cotini, Osi, Buri terga Marcomanorum Quadorumque claudunt. e quibus Marsigni et Buri sermone cultuque Suebos referunt: Cotinos Gallica, Osos Pannonica lingua coarguit non esse Germanos, et quod tributa patiuntur. 2. partem tributorum Sarmatae, partem Quadi ut alienigenis imponunt: Cotini, quo magis pudeat, et ferrum effodiunt. omnesque hi populi pauca campestrium, ceterum saltus et vertices montium [iugumque] insederunt. 3. dirimit enim scinditque Suebiam continuum montium iugum, ultra quod plurimae gentes agunt, ex quibus latissime patet Lugiorum nomen in plures civitates diffusum. valentissimas nominasse sufficiet, Harios, Helveconas, Manimos, Helisios, Naharvalos. 4. apud Naharvalos antiquae religionis lucus ostenditur. praesidet sacerdos muliebri ornatu, sed deos interpretatione Romana Castorem Pollucemque memorant. ea vis numini, nomen Alcis. nulla simulacra, nullum peregrinae superstitionis vestigium; ut fratres tamen, ut iuvenes venerantur. 5. ceterum Harii super vires, quibus enumeratos paulo ante populos antecedunt, truces insitae feritati arte ac tempore lenocinantur: nigra scuta, tincta corpora; atras ad proelia noctes legunt ipsaque formidine atque umbra feralis exercitus terrorem inferunt, nullo hostium sustinente novum ac velut infernum aspectum; nam primi in omnibus proeliis oculi vincuntur.

6. Trans Lugios Gotones regnantur, paulo iam adductius quam ceterae Germanorum gentes, nondum tamen supra libertatem. protinus deinde ab Oceano Rugii et Lemovii; omniumque harum gentium insigne rotunda scuta, breves gladii et erga reges obsequium.

XLIV. Suionum hinc civitates, ipso in Oceano, praeter viros armaque classibus valent. forma navium eo differt quod utrimque prora paratam semper adpulsui frontem agit. nec velis ministrant nec remos in ordinem lateribus adiungunt: solutum, ut in quibusdam fluminum, et mutabile, ut res poscit, hinc vel illinc remigium. 2. est apud illos et opibus honos, eoque unus imperitat, nullis iam exceptionibus, non precario iure parendi. 3. nec arma, ut apud ceteros Germanos, in promisco, sed clausa sub custode, et quidem servo, quia subitos hostium incursus prohibet Oceanus, otiosae porro armatorum manus facile lasciviunt: enimvero neque nobilem neque ingenuum, ne libertinum quidem armis praeponere regia utilitas est. 
XLIII. Atrás ${ }^{97}$, marsignos, cotinos, osos, búrios encerram as costas dos marcomanos e dos quados. Destes, marsignos e búrios assemelham-se aos suevos em idioma e modo; língua gálica e panônica comprovou que cotinos e osos não são germanos, e que aturam tributo. 2. Parte dos tributos impõem os sármatas, parte os quados, como a estrangeiros: os cotinos extraem também ferro, o que mais envergonha. E todos estes povos assentaram em pouco de planícies, de resto em desfiladeiros e cumes de montanhas e cadeias. 3. Contínua cadeia de montanhas divide e também cinde a Suévia, para além da qual vivem muitíssimas gentes, das quais o nome dos lúgios se espalha mais vastamente, difundido por vários povos. Suficiente nominar as mais valentes: hários, helveconas, manimos, helísios, naharvalos. 4. Entre os naaarvalos apresenta-se bosque de antiga santidade. Preside-o sacerdote com ornato feminino, mas recordam, conforme a interpretação romana, os deuses Castor e Pólux ${ }^{98}$. Este o poder do nume de nome Alcos. Nenhum simulacro, nenhum vestígio de superstição estrangeira; são venerados todavia como irmãos, como jovens. 5. Ademais, além da força pela qual antecedem os povos pouco antes enumerados, os hários ferozes acrescem à feridade inata por arte e momento: negros os escudos, pintados os corpos; escolhem as noites escuras para as pelejas, e, por medo mesmo e sombra, os exércitos ferais infundem terror, nenhum dos inimigos suporta o novo e como que infernal aspecto; com efeito, em todas as pelejas primeiro são vencidos os olhos.

6. Para além dos lúgios, os godos são reinados de modo um pouco mais duro que outras gentes dos germanos, todavia ainda não por cima de sua liberdade. Continuando daí, ao lado do Oceano os rúgios e lemôvios; marca de todas estas gentes escudos redondos, gládios curtos e obediência aos reis.

XLIV. Depois, no próprio Oceano, os povos dos suíones ${ }^{99}$ predominam por frotas, afora homens e armas. $\mathrm{O}$ formato dos navios difere a tal ponto que proa de ambos os lados faz frente sempre preparada para o desembarque; mas não lidam com velas nem ajuntam remos em ordem nos flancos: solto, tal como em alguns rios, e versátil, manobrável para cá e para lá tal como demanda a situação. 2. Entre eles também riqueza tem honra, e por isso um único governa agora com nenhuma limitação, através de direito de obediência

\footnotetext{
${ }^{97}$ Ao norte.

${ }^{98} \mathrm{O}$ culto aos gêmeos masculinos era bastante difundido no mundo chamado indo-europeu.

${ }^{99}$ Tribo que deu origem aos suecos. Deve-se lembrar que na época de Tácito se pensava que a Escandinávia era uma ilha, o que dá sentido à passagem.
} 
não questionável. 3. E nem as armas, como entre os demais germanos, em posse geral, mas fechadas sob guarda, servo em verdade, porque o Oceano inibe incursões súbitas de inimigos; além do mais, mãos ociosas de homens armados se excedem facilmente: efetivamente, não é de proveito do rei confiar armas a nobre ou a livre, ou mesmo a liberto. 
XLV. Trans Suionas aliud mare, pigrum ac prope immotum, quo cingi claudique terrarum orbem hinc fides, quod extremus cadentis iam solis fulgor in ortus edurat adeo clarus ut sidera hebetet; sonum insuper emergentis audiri formasque equorum et radios capitis aspici persuasio adicit. illuc usque et fama vera tantum natura. 2. ergo iam dextro Suebici maris litore Aestiorum gentes adluuntur, quibus ritus habitusque Sueborum, lingua Britannicae propior. matrem deum venerantur. 3. insigne superstitionis formas aprorum gestant: id pro armis hominumque tutela securum deae cultorem etiam inter hostes praestat. rarus ferri, frequens fustium usus. 4. frumenta ceterosque fructus patientius quam pro solita Germanorum inertia laborant. sed et mare scrutantur, ac soli omnium sucinum, quod ipsi glesum vocant, inter vada atque in ipso litore legunt. 5. nec quae natura quaeve ratio gignat, ut barbaris, quaesitum compertumve; diu quin etiam inter cetera eiectamenta maris iacebat, donec luxuria nostra dedit nomen. ipsis in nullo usu: rude legitur, informe perfertur, pretiumque mirantes accipiunt. 6. sucum tamen arborum esse intellegas, quia terrena quaedam atque etiam volucria animalia plerumque interlucent, quae implicata humore mox durescente materia clauduntur. 7. fecundiora igitur nemora lucosque, sicut Orientis secretis, ubi tura balsamaque sudantur, ita Occidentis insulis terrisque inesse crediderim, quae vicini solis radiis expressa atque liquentia in proximum mare labuntur ac vi tempestatum in adversa litora exundant. 8. si naturam sucini admoto igne temptes, in modum taedae accenditur alitque flammam pinguem et olentem; mox ut in picem resinamve lentescit.

9. Suionibus Sitonum gentes continuantur. cetera similes uno differunt, quod femina dominatur: in tantum non modo a libertate sed etiam a servitute degenerant.

XLVI. Hic Suebiae finis. Peucinorum Venethorumque et Fennorum nationes Germanis an Sarmatis adscribam dubito. quamquam Peucini, quos quidam Bastarnas vocant, sermone cultu sede ac domiciliis ut Germani agunt. sordes omnium ac torpor procerum: conubiis mixtis nonnihil in Sarmatarum habitum foedantur. 2. Venethi multum ex moribus traxerunt; nam quidquid inter Peucinos Fennosque silvarum ac montium erigitur latrociniis pererrant. hi tamen inter Germanos potius referuntur, quia et domos figunt et scuta gestant et pedum usu et pernicitate gaudent: quae omnia diversa Sarmatis sunt in plaustro equoque viventibus. 3. Fennis mira feritas, foeda paupertas: non arma, non equi, non penates; victui herba, vestitui pelles, cubile humus: solae in sagittis spes, quas inopia ferri ossibus asperant. idemque venatus viros pariter ac feminas alit; passim enim comitantur partemque praedae petunt. 4. nec aliud infantibus ferarum imbriumque 
suffugium quam ut in aliquo ramorum nexu contegantur; huc redeunt iuvenes, hoc senum receptaculum. 5. sed beatius arbitrantur quam ingemere agris, inlaborare domibus, suas alienasque fortunas spe metuque versare: securi adversus homines, securi adversus deos rem difficillimam adsecuti sunt, ut illis ne voto quidem opus esset. 6. cetera iam fabulosa: Hellusios et Oxionas ora hominum vultusque, corpora atque artus ferarum gerere: quod ego ut incompertum in medio relinquam. 
XLV. Para além ${ }^{100}$ dos suíones outro mar, parado e praticamente imóvel, pelo qual acredita-se o orbe terrestre é envolto e encerrado, pois a última luz do sol já poente dura até a aurora, a tal ponto brilhante que embota os astros; crença acrescenta que ouve-se o som dele emergindo e vê-se as formas dos cavalos e os raios de sua cabeça ${ }^{101}$. Natureza tão-só - e o rumor é verdadeiro - até lá. 2. Agora, porém, na costa oriental do mar suevo são banhadas as gentes dos estios, de quem ritos e aparência dos suevos, língua mais perto da britânica. Veneram a mãe dos deuses. 3. Trazem imagens de javali, marca da superstição: esta, em lugar de armas e proteção de homens, mantém o adorador da deusa a salvo também entre inimigos ${ }^{102}$. Raro o uso do ferro, frequente o do pau. 4 . Trabalham os grãos e outros frutos mais pacientemente do que faz crer a costumaz indolência dos germanos. Mas exploram também o mar, e sozinhos recolhem todo o âmbar, o qual eles próprios chamam de gleso, junto a vaus e na prória costa. 5. Mas como bárbaros, não investigaram nem descobriram sua natureza ou a maneira pela qual se forma; em realidade, há muito estava esquecido entre os refugos do mar, até que nossos luxos lhe deram nome. Para eles próprios não é de uso algum: é recolhido bruto, passado informe e, admirados, aceitam seu preço. 6. Poder-se-ia pensar todavia que é seiva das árvores, porque certos animais terrestres e também voadores geralmente brilham através dele, os quais, envolvidos pelo fluido, são depois encerrados no material que endurece. 7. Assim sendo, creio que existam florestas e bosques mais fecundos, tal como os do afastado Oriente onde incensos e bálsamos se evaporam, nas ilhas e terras do Ocidente, os quais, premidos pelos raios do vizinho sol, escoam líquidos para o mar próximo e os jorram, pela força das tempestades, para os litorais contrários. 8. Se testares a natureza do âmbar colocando fogo, acende-se ao modo de tocha e nutre abundante e perfumada chama; depois, torna-se viscoso como asfalto ou resina.

9. Aos suíones seguem-se as gentes dos sitos. No resto símiles, diferem em uma coisa, que vem a ser que a mulher domina: tanto degeneram não apenas do liberto, mas também do servo.

XLVI. Aqui o fim da Suévia. Não sei se atribuo a germanos ou sármatas as nações dos peucinos, venedos e dos fenos. Entretanto, os peucinos, os quais alguns chamam de

\footnotetext{
${ }^{100}$ Ao norte.

${ }^{101}$ O símbolo da carruagem solar puxada por cavalos era bastante difundido no mundo antigo; era presente também entre os germanos.

${ }^{102} \mathrm{O}$ javali era o animal sagrado dos deuses escandinavos Frey e Freja, ambos ligados a cultos da fertilidade.
} 
bastarnas, agem como germanos em idioma, modo, assentamento e moradia. Sujeira é de todos, preguiça dos próceres: por casamentos mistos estão um tanto poluídos com a aparência dos sármatas. 2. Os venedos tomaram muito de seus costumes; ora, percorrem com assaltos tudo o que de florestas e montanhas se eleva entre os peucinos e os fenos. Todavia estes são mencionados mais entre os germanos, porque fixam morada e carregam escudos e se regozijam do uso e agilidade de seus pés, o que é todo diverso nos sármatas, que vivem em carreta e cavalo. 3. Extraordinária a fereza dos fenos, horrível a pobreza: nem armas, nem cavalos, nem lares; ervas para subsistência, peles para o vestuário, chão por cama. Esperança solitária nas setas, as quais afilam com ossos, por falta de ferro. A mesma caça alimenta os homens e do mesmo modo as mulheres; de fato, elas os seguem em todo lugar e pedem parte da presa. 4. E às crianças nenhum outro abrigo das chuvas e feras que não serem cobertas com alguns ramos entrelaçados; ali retornam os jovens, este o refúgio dos velhos. 5. Mas julgam isso mais feliz que gemer nos campos, laborar nas casas, revolver as fortunas suas e dos outros com esperança e medo; seguros contra os homens, seguros contra os deuses, alcançaram a coisa mais difícil: para eles nem mesmo prece é necessária. 6. Daqui por diante o resto é de fábula: que os helúsios e oxionas têm rosto e expressão de homens, corpos e membros de feras, o que, como algo não esclarecido, deixarei em aberto. 


\section{Bibliografia}

R. Ambrosio (2002). Cícero e a história. In: Revista de História, 147: 9-31.

J. G. C. Anderson (1997). Tacitus Germania. Oxford: Clarendon Press.

H. E. Butler (1995). Quintilian Institutio Oratoria. London: Harvard University Press.

R. W. Cape Jr. (1997). Persuasive history: Roman rhetoric and historiography. In: Roman Eloquence: Rhetoric in Society and Literature. Ed: W. J. Dominik. London: Routledge, $155-67$.

E. Dench (2005). Romulus' Asylum. Oxford: Oxford University Press.

E. Dench (2007). "Ethnography and History". In: J. Marincola. A Companion to Roman and Greek Historiography. Vol. II. Oxford: Blackwell Publishing, 493-503.

C. H. Dibbern (2013). O êthos de Aníbal em Tito Lívio e Cornélio Nepos: imagines. Dissertação de Mestrado apresentada junto ao DLCV/PPGLC/FFLCH da Universidade de São Paulo sob a orientação do Prof. Dr. Paulo Martins.

H. Dubrow (1982). Genre. London and New York: Methuen.

C. W. Fornara (1983). The Nature of History in Ancient Greece and Rome. Berkeley, Los Angeles, London: University of California Press.

G. Genette (1969). Frontières du Récit. In: Figures II. Paris: Éditions du Seuil, 50-61.

A. Gudeman (1900). Tacitus Agricola and Germania. Boston: Allyn and Bacon.

J. A. Hansen (2006). Categorias epidíticas da ekphrasis. In: Revista USP, 71: 85-105.

P. Grimal (1990). Une terre de liberté. In: Tacite. Paris: Fayard, 127-49. 
G. L. Hendrickson, H. M. Hubbel (1962). Cicero Orator; Brutus. Cambridge: Harvard University Press.

M. Hutton (1970). Agricola, Germania, Dialogus. Cambridge and London: Harvard University Press.

C. Jacob (1990). Géographie et ethnographie en Grèce ancienne. Paris: Armand Colin.

F. Jacoby (1956). Über die Entwicklung der Griechischen Historiographie und den Plan einer neuen Sammlung der Griechischen Historikerfragmente. In: Abhandlungen zur griechischen Geschichtschreibung. Leiden: E. J. Brill, 16-63.

H. Jankuhn, D. Timpe (ed.) (1999). Beiträge zum Verständnis der Germania des Tacitus - Teil I. Göttingen: Vandenhoeck \& Ruprecht.

H. Lausberg (2004). Elementos de Retórica Literária. Lisboa: Fundação Calouste Gulbenkian.

A. A. Lund (1988). P. Cornelius Tacitus Germania. Heidelberg: Carl Winter Universitätverlag.

A. A. Lund (1990). Zum Germanenbild der Römer: Eine Einführung in die antike Ethnographie. Heidelberg: Carl Winter Universitätverlag.

J. Marincola (1999). Greco-Roman Historiography. In: The Limits of Historiography. Ed.: C. S. Kraus. Leiden, Boston, Köln: Brill, 282-324.

P. Martins (2011). Imagem e Poder. Considerações sobre a Representação de Otávio Augusto. São Paulo: Edusp.

P. Martins (2013). Pictura Loquens, Poesis Tacens: Limites da Representação. Tese de Livre-Docência defendida junto ao DLCV/PPGLC/FFLCH da Universidade de São Paulo. 
C. W. Mendell (1957). Tacitus: The Man and his Work. Oxford: Oxford University Press.

T. Mommsen (1905). Rede zur Feier des Geburtstages Friedrichs des Groszen. In: Rede und Aufsätze. Berlin: Weidmannsche Buchhandlung.

E. M. Müller (1997). Geschichte der antiken Ethnologie. Reinbek bei Hamburg: Rowohlt Taschenbuch Verlag.

E. Norden (1998). Die germanische Urgeschichte in Tacitus' Germania. Stuttgart und Leipzig: T. G. Teubner.

E. O' Gorman (1993). No place like Rome: identity and diference in the Germania of Tacitus. In: Remus, 22, 2: 135-54.

C. Pelling (1999). Epilogue. In: The Limits of Historiography. Ed.: C. S. Kraus. Leiden, Boston, Köln: Brill, 325-60.

J. Perret (1949). Tacite La Germanie. Paris: Les Belles Lettres.

E. Rawson (1985). Geography and Ethnography. In: Intelectual life in the Late Roman Republic. London: Duckworth; 250-66.

J. B. Rives (1999). Tacitus Germania. Oxford: Clarendon Press.

M. Rodolpho (2012). Écfrase e Evidência nas Letras Latinas: Doutrina e Práxis. São Paulo: Humanitas.

T. G. Rosenmeyer (2006). Ancient Literary Genres: A Mirage?. In: A. Laird (ed.). Oxford Readings in Ancient Literary Criticism. New York: Oxford University Press, 421-39.

L. E. Rossi (1971). I generi letterari e le loro leggi scritte e non scritte nelle letterature classiche. In: Institute of Classical Studies, 18: 69-94. 
G. Schepens (1997). Jacoby's FGrHist: Problems, Methods, Prospects. In: G. W. Most. Collecting Fragments/Fragmente sammeln. Göttingen: Vandenhoeck \& Ruprecht.

A. da Silva (1974). Tácito: Obras Menores. Lisboa: Livros Horizonte.

E. W. Sutton, H. Rackham (1988). Cicero De Oratore. Cambridge: Harvard University Press.

R. Syme (1958). Tacitus. Two Volumes. London: Oxford University Press.

R. F. Thomas (1982). Lands and Peoples in Roman Poetry: The Ethnographical Tradition. Cambridge: The Cambridge Philological Society.

D. Timpe (1999). "Ethlologische Begriffsbildung in der Antike". In: H. Beck (org.). Germanenprobleme in heutiger Sicht. Berlin und New York: Walter de Gruyter, 22-40.

T. Todorov (1981). Os Géneros do Discurso. Lisboa: Edições 70.

K. Trüdinger (1918). Studien zur Geschichte der grieschisch-römischen Ethlographie. Basel: Buchdruckrei Emil Birkhäuser. 